MARINA GRACINDA MODESTO

AVALIAÇÃO DO MOLIBDATO DE SÓDIO, TUNGSTATO DE SÓDIO E UM COPOLÍMERO A BASE DE SILANO COMO INIBIDORES DE CORROSÃO PARA O AÇO-CARBONO ABNT 1005 EM MEIO DE NaCI 3,5\% 
MARINA GRACINDA MODESTO

\section{AVALIAÇÃO DO MOLIBDATO DE SÓDIO, TUNGSTATO DE SÓDIO E UM COPOLÍMERO A BASE DE SILANO COMO INIBIDORES DE CORROSÃO PARA O AÇO-CARBONO ABNT 1005 EM MEIO DE NaCI 3,5\%}

Dissertação apresentada à Escola Politécnica da Universidade de São Paulo para a obtenção do Título de Mestre em Engenharia 
MARINA GRACINDA MODESTO

\section{AVALIAÇÃO DO MOLIBDATO DE SÓDIO, TUNGSTATO DE SÓDIO E UM COPOLÍMERO A BASE DE SILANO COMO INIBIDORES DE CORROSÃO PARA O AÇO-CARBONO ABNT 1005 EM MEIO DE NaCI 3,5\%}

Dissertação apresentada à Escola Politécnica da Universidade de São Paulo para a obtenção do título de Mestre em Engenharia

Área de Concentração:

Engenharia Química

Orientador: Prof ${ }^{a}$ Dra. Isabel Correia Guedes

São Paulo

2008 
Este exemplar foi revisado e alterado em relação à versão original, sob responsabilidade única do autor e com a anuência de seu orientador.

São Paulo, de setembro de 2008.

Assinatura do autor

Assinatura do orientador

FICHA CATALOGRÁFICA

Modesto, Marina Gracinda

Avaliação do molibdato de sódio, tungstato de sódio e um copolímero a base de silano como inibidores de corrosão para o aço-carbono ABNT 1005 em meio de $\mathrm{NaCl}$ 3,5\% / M.G. Modesto. - ed.rev. -- São Paulo, 2008.

$91 \mathrm{p}$.

Dissertação (Mestrado) - Escola Politécnica da Universidade de São Paulo. Departamento de Engenharia Química.

1. Aço carbono 2.Cloreto de sódio 3.Corrosão 4.Inibidores de corrosão I.Universidade de São Paulo. Escola Politécnica.

Departamento de Engenharia Química II.t. 
Ao meu marido Fabiano pelas árduas horas de estudo roubadas ao seu convívio, fonte permanente de apoio e inspiração.

Aos meus pais, Isolina e Ribamar, pelo exemplo e incentivo a mim dispensados nos momentos mais difíceis. 


\section{AGRADECIMENTOS}

Sempre a Deus e a Nossa Senhora Aparecida.

Aos meus pais Ribamar e Isolina, ao meu marido Fabiano, às minhas irmãs Juliana e Carolina, e aos meus tios Sandra e Zé pela constante ajuda e apoio.

A Prof ${ }^{a}$ Dra. Isabel Correia Guedes pela orientação constante para o desenvolvimento deste trabalho

A técnica e amiga Tereza pela colaboração, apoio e auxílio na organização da parte experimental do trabalho e ao técnico Antônio Carlos pela amizade

A amiga Glorys pelo constante incentivo para o desenvolvimento deste trabalho.

Aos professores Hercílio e Idalina pelo enriquecimento do trabalho e a Zehbour pela inspiração sobre o assunto "corrosão".

Aos meus colegas do Laboratório de Eletroquímica e Corrosão: Rocio, Vera, Patrícia, Isabela, Sérgio, Jean, Marina, Luis, Márcia, Marcelo, Juliana e Paulo.

A Graça, Alexandre e Elisete pela sempre alegre atenção.

Ao Departamento de Engenharia Química da Escola Politécnica da Universidade de São Paulo - PQI/POLI-USP, pela oportunidade e facilidades concedidas para 0 desenvolvimento deste trabalho.

Agradeço ao SENAI-SP, principalmente a Diretora da Escola SENAI Mario Amato Silvia Helena Carabolante e a Coordenadora do Curso Técnico de Química Ana Rita Galhardo Tur pela oportunidade do desenvolvimento deste trabalho. 
"O que ocorre com a Terra recairá sobre os Filhos da Terra. O Homem não teceu o tecido da vida: ele é simplesmente um de seus fios. Tudo o que fizer ao tecido, fará a si mesmo." 


\section{RESUMO}

$\mathrm{O}$ objetivo deste trabalho consiste em avaliar o molibdato de sódio $\left(\mathrm{Na}_{2} \mathrm{MoO}_{4}\right)$, $\mathrm{O}$ tungstato de sódio $\left(\mathrm{Na}_{2} \mathrm{WO}_{4}\right)$ e um copolímero a base de silano "polioxialquileno e polidimetilsiloxano modificado" (CPPM) como inibidores de corrosão para o açocarbono ABNT 1005 em meio de $\mathrm{NaCl} 3,5 \%$. O estudo compreendeu na exposição do metal no meio proposto na ausência e presença de concentrações crescentes das substâncias estudadas. As técnicas utilizadas foram: ensaios de imersão com medida de perda de massa; medida de potencial de corrosão ( $\left.E_{\text {corr }}\right)$; espectroscopia de impedância eletroquímica (EIE) e curvas de polarização potenciodinâmicas anódicas e catódicas $\left(\mathrm{C}_{\mathrm{pol}}\right)$. Os resultados dos ensaios de imersão com medida de perda de massa mostraram que a velocidade de corrosão do aço-carbono ABNT 1005 em meio de água do mar é menor que a velocidade de corrosão em meio de $\mathrm{NaCl} 3,5 \%$. Os valores de potenciais de corrosão mostraram que $\circ \mathrm{Na}_{2} \mathrm{MoO}_{4} \mathrm{e}$ $\mathrm{Na}_{2} \mathrm{WO}_{4}$ deslocaram os potenciais para valores mais positivos indicando um comportamento de inibidores anódicos. Os parâmetros obtidos pela técnica de EIE mostraram que para o $\mathrm{Na}_{2} \mathrm{MoO}_{4}$ o melhor tempo de imersão foi de 6 horas e para o $\mathrm{Na}_{2} \mathrm{WO}_{4}$ foi de 12 horas, com eficiências de $70 \%$ e $77 \%$, respectivamente. As $\mathrm{C}_{\mathrm{pol}}$ confirmaram os resultados de potenciais de corrosão, ou seja, onde tanto 0 $\mathrm{Na}_{2} \mathrm{MoO}_{4}$ quanto o $\mathrm{Na}_{2} \mathrm{WO}_{4}$ comportaram-se como inibidores anódicos para o açocarbono ABNT 1005 em meio de $\mathrm{NaCl} 3,5 \%$. O valor de perda de espessura com a presença de $1 \times 10^{-2} \mathrm{~mol}^{-\mathrm{L}^{-1}}$ de $\mathrm{Na}_{2} \mathrm{MoO}_{4}$ com 24 horas de imersão comparado com o valor obtido em $\mathrm{NaCl} 3,5 \%$ sem inibidor forneceu uma eficiência de $82 \%$, enquanto que na presença de $\mathrm{Na}_{2} \mathrm{WO}_{4}$, também com 24 horas de imersão e na concentração de $1 \times 10^{-2}$ mol. $L^{-1}$, a eficiência foi de $65 \%$. Os resultados obtidos com o CPPM mostraram que esta substância não age como inibidor de corrosão para 0 açocarbono ABNT 1005 em meio de $\mathrm{NaCl} 3,5 \%$. 


\begin{abstract}
The aim of this study is to evaluate the sodium molybdate $\left(\mathrm{Na}_{2} \mathrm{Mo}_{4}\right)$, sodium tungstate $\left(\mathrm{Na}_{2} \mathrm{WO}_{4}\right)$ and polydimethyl-siloxane modified copolymer (CPPM) as corrosion inhibitors for the carbon steel ABNT 1005 in 3,5\% NaCl media. The metal substrate was exposed in the media with absence and presence of increasing concentrations of the investigated substances. The techniques used were: mass loss tests; open circuit potential; potentiodynamic polarization $\left(\mathrm{C}_{\mathrm{pol}}\right)$ and electrochemical impedance spectroscopy (EIS). For comparative purpose, mass loss testes were carried out in seawater and in 3,5\% NaCl. The results showed that carbon steel ABNT 1005 corrosion rate in seawater is lower than the corrosion rate at 3,5\% $\mathrm{NaCl}$. The $\mathrm{Na}_{2} \mathrm{Mo}_{4}$ and $\mathrm{Na}_{2} \mathrm{WO}_{4}$ corrosion potentials showed more positive values than their absence, indicating an anodic inhibitor behavior. The parameters obtained by EIS technique showed that for the $\mathrm{Na}_{2} \mathrm{MoO}_{4}$ the best time of immersion was 6 hours and the $\mathrm{Na}_{2} \mathrm{WO}_{4}$ was 12 hours, with efficiencies of $70 \%$ and $77 \%$ respectively. The $\mathrm{C}_{\mathrm{pol}}$ results confirmed the anodic behavior as corrosion inhibitors of the $\mathrm{Na}_{2} \mathrm{MoO}_{4}$ and $\mathrm{Na}_{2} \mathrm{WO}_{4}$ for carbon steel ABNT 1005 in 3,5\% NaCl. After 24 hours of immersion in $1,0 \times 10^{-2} \mathrm{~mol}^{-1} \mathrm{La}_{2} \mathrm{MoO}_{4}$ presence, the corrosion inhibition efficiency estimed using Tafel extrapolation was $82 \%$. In the $1 \times 10^{-2} \mathrm{~mol}^{-1} \mathrm{~L}^{-1} \mathrm{Na}_{2} \mathrm{WO}_{4}$ presence after 24 hours of immersion, the efficiency obtained was 65\%. The CPPM results showed it not acting as corrosion inhibitor for carbon steel ABNT 1005 in $3.5 \% \mathrm{NaCl}$.
\end{abstract}




\section{LISTA DE FIGURAS}

Figura 2.1 - Ciclo dos metais............................................................... 21

Figura 2.2 - Processo de corrosão do ferro................................................ 22

Figura 2.3 - Âncora de barco de pescador.................................................. 24

Figura 2.4 - Representação gráfica do efeito do inibidor anódico.................. 27

Figura 2.5 - Representação gráfica do efeito do inibidor catódico.................. 28

Figura 2.6 - Representação gráfica do efeito do inibidor misto....................... 28

Figura 2.7 - Representação esquemática da dupla camada elétrica.............. 30

Figura 2.8 - Circuito elétrico equivalente do sistema metal/eletrólito.............. 50

Figura 2.9 - Diagramas de Nyquist e Bode para o sistema metal/eletrólito... 50

Figura 2.10 - Diagramas de Nyquist para sistema com características capacitivas (a e b) e características resistivas (c)

Figura 2.11 - Efeito do inibidor sobre os diagramas de Nyquist..................... 53

Figura 3.1 - Arranjo esquemático para as medidas eletroquímicas, sendo que: $E T$ - eletrodo de trabalho; $E R$ - eletrodo de referência; $C E$ - contra eletrodo

Figura 4.1 - Impedância eletroquímica para o aço-carbono ABNT 1005 em $\mathrm{NaCl}$ 3,5\% na ausência das substâncias estudadas como inibidores de corrosão

Figura 4.2 - Circuito elétrico equivalente para a representação do sistema estudado.

Figura 4.3 - Diagramas de impedância para o aço-carbono ABNT 1005 obtidos com 3 horas de imersão em meio de $\mathrm{NaCl} 3,5 \%$ na ausência e presença de $\mathrm{Na}_{2} \mathrm{MoO}_{4}$.

Figura 4.4 - Evolução dos diagramas de impedância para o aço-carbono ABNT 1005 obtidos em $\mathrm{NaCl} 3,5 \%$ com $1 \times 10^{-2}$ mol.L-1 de $\mathrm{Na}_{2} \mathrm{MoO}_{4}$ o tempo de imersão 
Figura 4.5 - Diagramas de impedância para o aço-carbono ABNT 1005 obtidos com 3 horas de imersão em meio de $\mathrm{NaCl} 3,5 \%$ na ausência e presença de $\mathrm{Na}_{2} \mathrm{WO}_{4}$

Figura 4.6 - Diagramas de impedância para o aço-carbono ABNT 1005 obtidos em meio de $\mathrm{NaCl} 3,5 \%$ com $1 \times 10^{-2} \mathrm{~mol}^{-1} \mathrm{~L}^{-1}$ de $\mathrm{Na}_{2} \mathrm{WO}_{4}$ com o tempo de imersão

Figura 4.7 - Diagramas de impedância para o aço-carbono ABNT 1005 obtidos com 3 horas de imersão em meio de $\mathrm{NaCl} 3,5 \%$ na ausência e presença do CPPM.

Figura 4.8 - Curvas de polarização potenciodinâmicas anódicas e catódicas para o aço-carbono ABNT 1005 em meio de $\mathrm{NaCl}$ 3,5\%.

Figura 4.9 - Curvas de polarização potenciodinâmicas anódicas e catódicas para o aço-carbono ABNT 1005 em meio de $\mathrm{NaCl}$ 3,5\% na ausência e presença de $\mathrm{Na}_{2} \mathrm{MoO}_{4}$, com 6 horas de imersão.

Figura 4.10 - Curvas de polarização potenciodinâmicas anódicas e catódicas para o aço-carbono ABNT 1005 em meio de $\mathrm{NaCl}$ 3,5\% na ausência e presença de $\mathrm{Na}_{2} \mathrm{WO}_{4}$, com 12 horas de imersão.

Figura 4.11 - Curvas de polarização potenciodinâmicas anódicas e catódicas para o aço-carbono ABNT 1005 em meio de $\mathrm{NaCl}$ 3,5\% na ausência e presença do $\mathrm{Na}_{2} \mathrm{MoO}_{4}$, com 24 horas de imersão.

Figura 4.12 - Curvas de polarização potenciodinâmicas anódicas e catódicas para o aço-carbono ABNT 1005 em meio de $\mathrm{NaCl}$ 3,5\%, na ausência e presença do $\mathrm{Na}_{2} \mathrm{WO}_{4}$, com 24 horas de imersão.

Figura 4.13 - Curvas de polarização potenciodinâmicas anódicas e catódicas para o aço-carbono ABNT 1005 em meio de $\mathrm{NaCl}$ 3,5\%, na ausência e presença do CPPM, com 24 horas de imersão. 


\section{LISTA DE TABELAS}

Tabela 3.1 - Composição química do aço-carbono ABNT 1005 utilizado neste estudo

Tabela 4.1 - $\quad$ Valores da velocidade de corrosão $V_{\text {corr }}$ e perda de espessura P.E. do aço-carbono 1005 em água do mar e em meio de $\mathrm{NaCl} 3,5 \% \mathrm{com}$ o tempo de imersão.

Tabela 4.2 - Valores de potencial de corrosão para o aço ABNT 1005 em meio de $\mathrm{NaCl} 3,5 \%$, na ausência e presença das substâncias estudadas como inibidores de corrosão e para tempo de imersão de 3 horas, 6 horas, 12 horas e 24 horas.

Tabela 4.3 - Parâmetros estimados a partir do ajuste dos dados experimentais obtidos com o aço-carbono ABNT 1005 em meio de $\mathrm{NaCl} 3,5 \%$ na ausência das substâncias estudadas

Tabela 4.4 - Parâmetros estimados a partir do ajuste dos dados experimentais obtidos com o aço-carbono ABNT 1005 por 3 horas de imersão em meio de $\mathrm{NaCl} 3,5 \%$ na ausência e presença de $\mathrm{Na}_{2} \mathrm{MoO}_{4}$

Tabela 4.5 - Evolução com o tempo de imersão dos parâmetros estimados a partir do ajuste dos dados experimentais para o aço-carbono ABNT 1005 em meio de $\mathrm{NaCl} 3,5 \%$ com $1 \times 10^{-2} \mathrm{~mol}^{-L^{-1}}$ de $\mathrm{Na}_{2} \mathrm{MoO}_{4}$

Tabela 4.6 - Parâmetros estimados a partir do ajuste dos dados experimentais obtidos com o aço-carbono ABNT 1005 por 3 horas de imersão em meio de $\mathrm{NaCl} 3,5 \%$ na ausência e presença de $\mathrm{Na}_{2} \mathrm{WO}_{4}$.

Tabela 4.7 - Evolução com o tempo de imersão dos parâmetros estimados a partir do ajuste dos dados experimentais para o aço-carbono ABNT 1005 em meio de $\mathrm{NaCl} 3,5 \%$ com $1 \times 10^{-2} \mathrm{~mol}^{-L^{-1}}$ de $\mathrm{Na}_{2} \mathrm{WO}_{4}$

Tabela 4.8 - Parâmetros estimados a partir do ajuste dos dados experimentais obtidos com o aço-carbono ABNT 1005 por 3 horas de imersão em meio de $\mathrm{NaCl} 3,5 \%$ na ausência e presença do CPPM

Tabela 4.9 - Valores de densidade de corrente de corrosão, $i_{c o r r}$, velocidades de corrosão, $V_{\text {corr, }}$ e perda de espessura, P.E., do aço-carbono ABNT 1005 em meio de $\mathrm{NaCl} 3,5 \%$ 
Tabela 4.10 - Valores de densidade de corrente de corrosão, $i_{\text {corr }}$, velocidades de corrosão, $V_{\text {corr, }}$ e perda de espessura, P.E., do aço-carbono ABNT 1005 em meio de $\mathrm{NaCl} 3,5 \%$, na ausência e presença de $\mathrm{Na}_{2} \mathrm{MoO}_{4}$ (com 6 horas de imersão) e $\mathrm{Na}_{2} \mathrm{WO}_{4}$ (com 12 horas de imersão).........

Tabela 4.11- Valores de densidade de corrente de corrosão $i_{\text {corr }}$, velocidades de

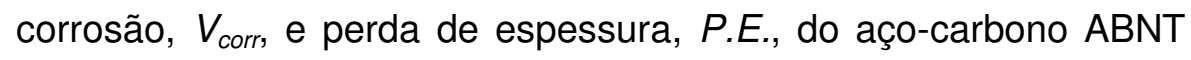
1005 em meio de $\mathrm{NaCl} 3,5 \%$, na ausência e presença das substâncias estudadas, com 24 horas de imersão.............................. 


\section{LISTA DE SÍMBOLOS}

\begin{tabular}{ll} 
CPPM & Polioxialquileno e polidimetilsiloxano modificado \\
PHI & Plano interno de Helmholtz \\
PHE & Plano externo de Helmholtz \\
cmc & Concentração de micela crítica \\
$E$ & Potencial elétrico \\
$i$ & Densidade de corrente \\
$E_{c o r r}$ & Medidas de potencial de corrosão \\
ET & Eletrodo de trabalho \\
ER & Eletrodo de referência \\
SCE & Eletrodo de calomelano saturado \\
CE & Contra eletrodo \\
$C_{p o l}$ & Curvas de polarização \\
$E I E$ & Espectroscopia de impedância eletroquímica \\
$i_{c o r r}$ & Densidade de corrente de corrosão \\
$V_{c o r r}$ & Velocidade de corrosão \\
$Z$ & Impedância \\
$Z$ & Componente real da impedância \\
$Z$ & Componente imaginário da impedância \\
$|Z|$ & Módulo da impedância \\
$R_{S}$ & Resistência da solução \\
\hline &
\end{tabular}




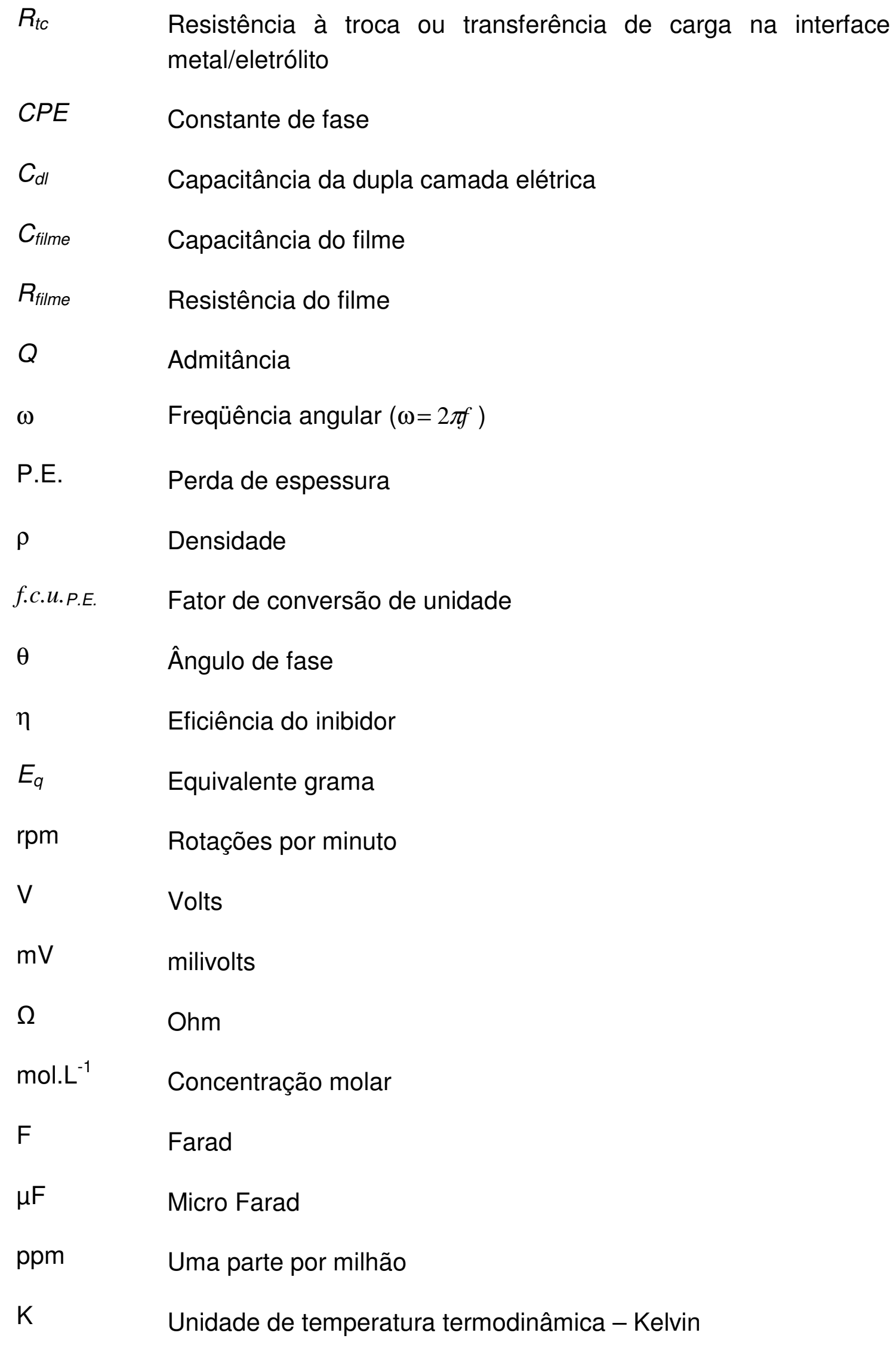




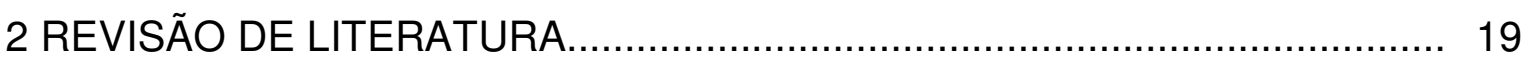

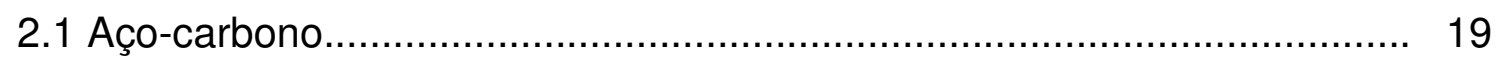

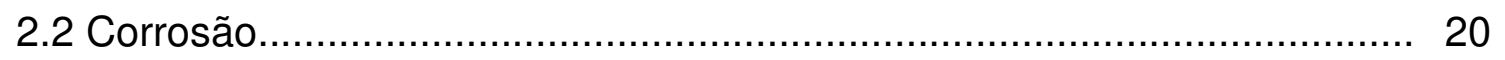

2.2.1 Corrosão do aço-carbono em água do mar....................................... 23

2.3 Inibidores de corrosão................................................................... 24

2.3.1 Classificação dos inibidores......................................................... 26

2.3.2 Processos de adsorção dos inibidores......................................... 29

2.4 Controle da corrosão pelo uso de inibidores de corrosão.......................... 32

2.4.1 Molibdato e Tungstato ............................................................... 33

2.4.1.1 Aplicação do molibdato de sódio como inibidor de corrosão........ 33

2.4.1.2 Aplicação do tungstato de sódio como inibidor de corrosão......... 40

2.4.1.3 Sinergismo entre o molibdato de sódio e do tungstato de sódio como inibidores de corrosão.................................................... 41

2.4.2 Aplicação dos silanos e tensoativos como inibidores de corrosão.... 44

2.4.3 Inibidores multicomponentes....................................................... 47

2.5 Espectroscopia de Impedância Eletroquímica (EIE)............................. 49

3 MATERIAIS E MÉTODOS ............................................................. 54

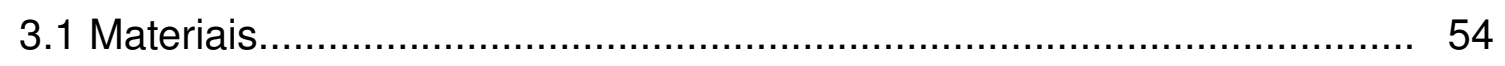

3.2 Metodologia............................................................................. 55

3.2.1 Preparação dos corpos-de-prova (tratamento superficial)................ 55

3.2.2 Técnicas empregadas neste estudo............................................... 55 
3.2.2.1 Ensaios de imersão com medida de perda de massa

3.2.2.2 Ensaios eletroquímicos.

4 RESULTADOS E DISCUSSÕES.............................................................. 58

4.1 Ensaios de imersão com medida de perda de massa............................. 58

4.2 Medidas de potencial de corrosão .......................................................6 60

4.3 Espectroscopia de impedância eletroquímica (EIE).............................. 61

4.3.1 Resultados de EIE para tempos crescentes de imersão..................... 61

4.3.2 Resultados de EIE para o aço ABNT 1005 em meio de $\mathrm{NaCl} 3,5 \%$

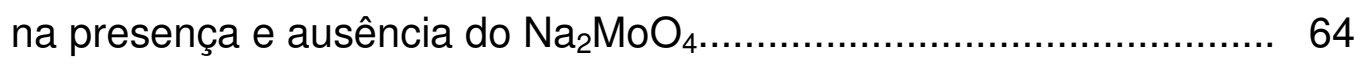

4.3.3 Resultados de EIE para o aço ABNT 1005 em meio de $\mathrm{NaCl} 3,5 \%$

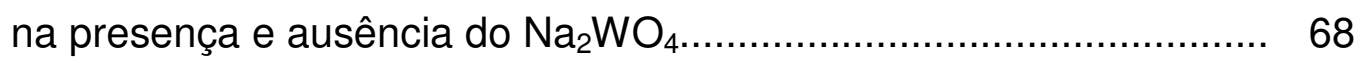

4.3.4 Resultados de EIE para o aço ABNT 1005 em meio de $\mathrm{NaCl} 3,5 \%$ na presença e ausência do CPPM................................................... 73

4.4 Curva de polarização potenciodinâmicas anódicas e catódicas $\left(\mathrm{C}_{\mathrm{pol}}\right) \ldots \quad 75$

5 CONCLUSÕES 83

REFERÊNCIAS 85 


\section{INTRODUÇÃO}

A presença de sais e principalmente de cloretos nas águas naturais acabam por acelerar a corrosão do aço-carbono e influenciar nas características da camada de óxidos e/ou hidróxidos tornando-a menos protetora. Sendo assim, o uso do açocarbono em ambiente marinho deve estar atrelado a algum tipo de proteção contra a corrosão, que pode ser feito através do uso de inibidores de corrosão, biocidas, extratores de oxigênio, revestimentos, além do uso da proteção catódica. O controle da corrosão é importante para aumentar a vida útil dos equipamentos, minimizar a geração de sólidos suspensos e ainda controlar os riscos ambientais (PATTON, 1993).

$\mathrm{Na}$ indústria petrolífera o uso de inibidores proporciona boa proteção contra a corrosão tanto nos equipamentos do processo de prospecção como nos equipamentos do processo de refino do petróleo, favorecendo a conservação dos equipamentos e evitando prejuízos operacionais (MAINIER, 2004).

No histórico do uso de inibidores de corrosão verifica-se que em meados de 1920 os produtos eram praticamente inócuos. Contudo, no início da década de 30 foi introduzido o uso de cromato como inibidor de corrosão. O uso do cromato como inibidor de corrosão foi provocado pelo desenvolvimento das indústrias que exigiam produtos mais eficientes, tanto que a American Society of Refrigeration of Engineers recomendava o uso de cromato de sódio para a proteção do aço-carbono imerso em cloreto de sódio ou cloreto de cálcio (SPELLER, 1930, 1935).

No entanto, a partir de 1980, com o advento da obrigatoriedade do estudo de impactos ambientais, o uso do cromato passou a ser questionado devido a sua elevada toxidez. Este movimento gerou discussões e debates, sempre com o objetivo de substituir o cromato como inibidor de corrosão. Vários trabalhos vêm sendo desenvolvidos, sempre com o intuito de encontrar substâncias que, além de não agredir o meio ambiente, possam inibir os processos corrosivos dos materiais metálicos e em especial o processo corrosivo do aço-carbono. (MAINIER; MARQUES, 1991 apud MAINIER; SILVA, 2004). 
O molibdato de sódio e o tungstato de sódio, por serem substâncias com baixa toxidez, vêm sendo estudados há algum tempo como inibidores de corrosão para o aço-carbono. Estas substâncias agem como inibidores anódicos de corrosão para o aço-carbono em meio neutro. O mecanismo de inibição do molibdato de sódio e do tungstato de sódio é através da adsorção competitiva com o íon cloreto e da modificação do filme de passivação (VIRTANEN; SURBER; NYLUND, 2000; ABDALLAH et al 2006).

Os tensoativos a base de silano, por serem também substâncias de baixa toxidez, foram estudados como inibidores de corrosão para o aço-carbono em meio de ácido clorídrico e os resultados mostraram que estes agem como bons inibidores de corrosão, e que o mecanismo de atuação é o de adsorção na superfície do metal através do grupo polar, enquanto que a parte apolar estende-se para a solução (SOUZA, 2005).

Este trabalho tem como objetivo avaliar o comportamento do molibdato de sódio, do tungstato de sódio e um tensoativo a base de silano como inibidores de corrosão para o aço ABNT 1005 em meio de $\mathrm{NaCl} 3,5 \%$ a temperatura ambiente. 


\section{REVISÃO DA LITERATURA}

\subsection{Aço-carbono}

O aço-carbono é uma liga ferrosa constituída de ferro e carbono, além de frações de elementos de liga que podem estar presentes como impurezas (CHIAVERINI, 2002; PANOSSIAN, 2003).

A combinação de baixo custo, associada à boa resistência mecânica e a fácil manipulação, torna o aço-carbono muito atrativo para a construção de estruturas e equipamentos. Essas características permitem ao aço-carbono ser o material mais utilizado na engenharia e na indústria. As propriedades mecânicas do aço-carbono permitem o seu uso na maioria das aplicações práticas mesmo na ausência de qualquer tratamento térmico (NOGUEIRA, 2002).

No Brasil o uso do aço esta relacionado diretamente com a história do país. No fim do século dezenove, quando o Brasil ainda não possuía indústria siderúrgica, grande quantidade do aço era importada da Inglaterra para a construção das ferrovias brasileiras. No período entre as duas grandes Guerras Mundiais, quando as importações foram paralisadas, o parque siderúrgico brasileiro foi desenvolvido. Hoje a siderurgia brasileira é considerada a sétima mais importante do mundo, com grande parte de sua produção direcionada para o mercado internacional (BATISTA, 2005). As principais aplicações do aço-carbono no Brasil são: na construção civil; na indústria automotiva; nas ferrovias; nas torres de transmissão; nas estacas; na construção naval; nas plataformas Off-Shore; nas máquinas; nos equipamentos; nos tanques; nas tubulações industriais, etc. Porém, grande parte destas aplicações está sujeita a exposição a ambientes agressivos, como é o caso da exposição a atmosfera marítima.

Nos últimos anos, graças ao desenvolvimento de tecnologias que possibilitam a exploração de reservatórios de petróleo Off-Shore (marítimas), a indústria de petróleo e gás brasileira está em expansão. A preocupação com a utilização de tecnologias mais seguras, adequadas à nova realidade da indústria de 
petróleo, como o uso de materiais resistente também vêm sendo estudado, porém o aço-carbono ainda está presente em grande parte dos equipamentos das plataformas Off-Shore e das plantas de processamento. O petróleo bruto (mistura de óleo, gás e água) é o insumo da planta de processo, sendo então convertido em cinco componentes de saídas, que são: óleo, gás, água salina, resíduos sólidos e efluentes gasosos (MAIA; BARROS, 2003). O petróleo bruto e os produtos do processamento contêm elementos que aceleram a corrosão do aço-carbono, como enxofre, microorganismos e o cloreto de sódio. Para preservar os equipamentos contra a corrosão, a indústria do petróleo investe em tecnologias que não provoquem riscos ambientais e que sejam eficientes contra a corrosão, como é o caso dos inibidores de corrosão com baixa toxidez.

\subsection{Corrosão}

A origem da palavra corrosão vem do latin "corrodere" que significa atacar, consumir (KHODAKOV, 1984, p.134). É comum definir a corrosão como sendo a deterioração dos materiais metálicos ou não-metálicos, pela ação química ou eletroquímica do meio, podendo ou não estar associada a esforços mecânicos. Em geral, os metais reagem com o meio ambiente, muitas vezes com o próprio oxigênio da atmosfera, gerando como produtos da corrosão compostos semelhantes aos que Ihes deram origem. Nestes casos a corrosão é definida como o inverso do processo metalúrgico. (DURIN, 1991; NUNES, 2007; GENTIL, 1982).

Para a produção da maioria dos metais é cedida ao minério uma grande quantidade de energia. Parte desta energia permanece no material aumentando a energia interna do elemento metálico. Este aumento da energia interna deixa o metal em um estado energético superior ao do minério de origem. Porém, de acordo com a segunda lei da termodinâmica, à temperatura e pressão constantes, a direção espontânea de ocorrência de um processo é a direção da redução da energia até o equilíbrio ser atingido. Sendo assim, em geral, os metais tendem espontaneamente a reagirem com o meio ao qual são expostos, ou seja, a transformação do metal em 
compostos (minério). Por exemplo, é o que ocorre quando o ferro é exposto ao oxigênio da atmosfera, transformando-se em óxidos de ferro (minério de ferro) muito mais estável que o próprio ferro (DUTRA, 2006; FAVAHERDASHTI, 2000; GRUNDIG, 1971).

A Figura 2.1 representa o ciclo energético que envolve o processo de produção e deterioração (corrosão) para os metais.

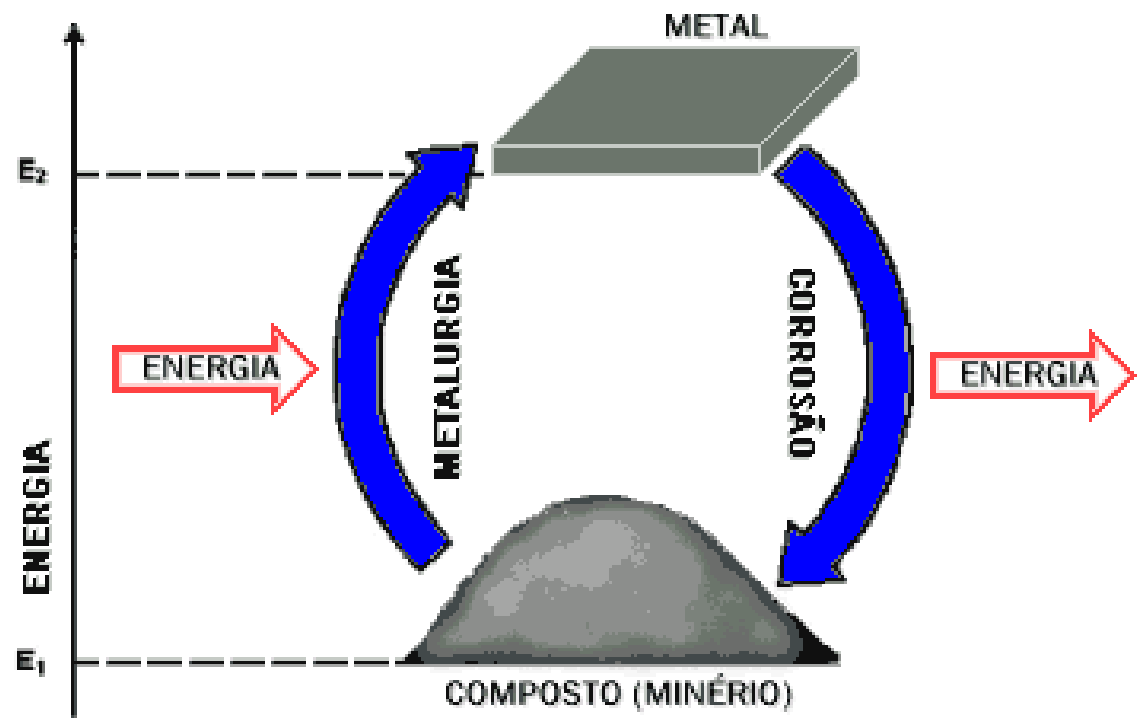

Figura 2.1 - Ciclo dos metais (NUNES, 2007).

Assim, pode-se afirmar que a corrosão é uma reação natural e ocorre espontaneamente em conseqüência das reações químicas e/ou eletroquímicas entre o metal e o meio, conhecidas também como reações de óxido-redução. Do ponto de vista técnico e econômico, deve-se trabalhar com o intuito de minimizar ou evitar que estas reações ocorram (SHREIR, 1994; ATKINS, 1999).

As conseqüências provenientes dos processos corrosivos vão desde o maior consumo de energia, redução do tempo de vida útil de estruturas e equipamentos, contaminação tanto dos produtos como do ambiente. Estima-se que os gastos econômicos de um país devido aos processos corrosivos são em torno de 3,5\% do PIB - Produto Interno Bruto (MIKSIC, 2004; PERRY, 1997; FAVAHERDASHTI, 2000). 
A literatura mostra que $98 \%$ dos casos de corrosão ocorrem por ação eletroquímica do meio (WOLYNEC, 2003).

A Figura 2.2 ilustra um processo de corrosão eletroquímica que ocorre em uma película de água depositada sobre uma superfície metálica. O anodo é o local onde o metal é corroído, a solução eletricamente condutora é o meio corrosivo e o catodo é parte da mesma superfície metálica ou outro metal em contato com ela. Vários são os fatores que determinam a criação e distribuição de regiões anódicas e catódicas na superfície do metal, dentre elas a existência de diferentes composições químicas, microestruturas do metal, tensões residuais, concentrações do meio e a velocidade de eletrólitos (ABNT/CB-CB 28, 2007).
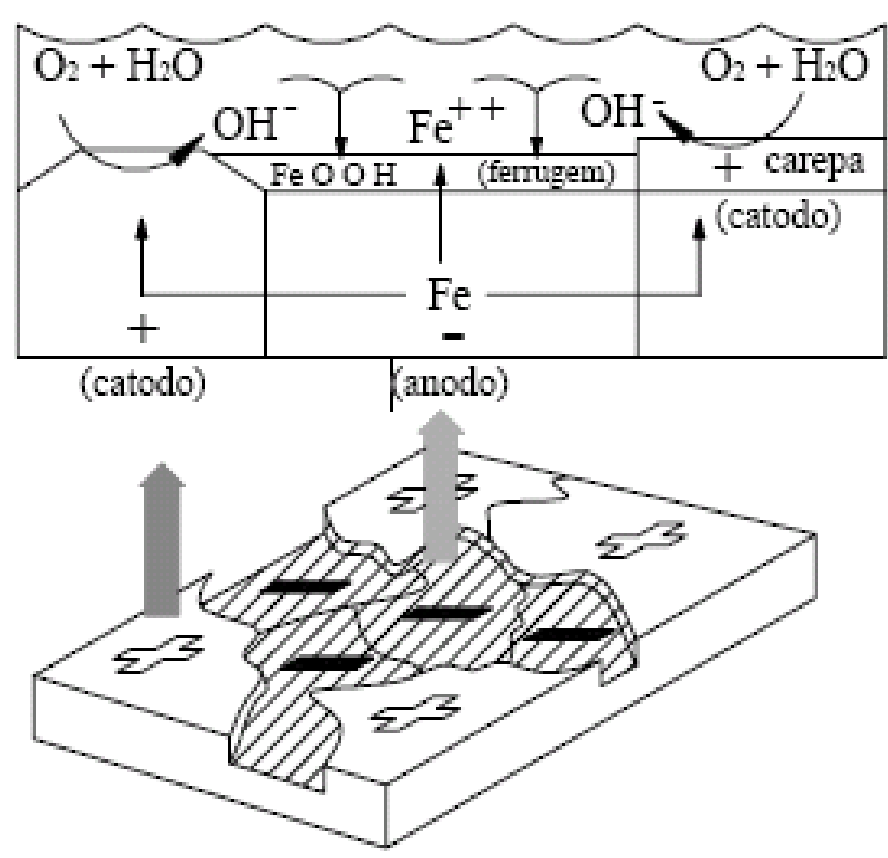

$$
\begin{aligned}
& \text { Anodo : } \mathrm{Fe} \rightarrow \mathrm{Fe}^{++}+2 \mathrm{e}^{-} \\
& \text {Catodo }: 1 / 2 \mathrm{O}_{2}+\mathrm{H}_{2} \mathrm{O}+2 \mathrm{e}^{-} \rightarrow 2 \mathrm{OH}^{-} \\
& \mathrm{Na} \text { fenugem }: \mathrm{Fe}^{++}+2 \mathrm{OH}^{-} \rightarrow \mathrm{Fe}(\mathrm{OH})_{2} \\
& \mathrm{Fe}(\mathrm{OH})_{2} \rightarrow \mathrm{Fe}(\mathrm{OH})_{3} \text { (oxidação ao ar) } \\
& \mathrm{Fe}(\mathrm{OH})_{3} \rightarrow \mathrm{FeOOH} \text { (transforma ção) } \\
& \mathrm{FeOOH}=\text { ferrugem }
\end{aligned}
$$

Figura 2.2 - Processo de corrosão do ferro (fonte: ABNT/CB-CB 28, 2007).

Embora haja uma grande complexidade envolvendo o tema corrosão, sabese que a corrosão do metal ocorre devido à formação de uma célula eletroquímica entre o metal e o sistema (GENTIL, 1983; CHIAVERINI, 2002; SASTRI, 1998; GRUNDIG, 1971). Existem várias técnicas que permitem determinar a velocidade de corrosão além de estimar os mecanismos básicos da corrosão. Porém nem sempre é possível prever com precisão todos os parâmetros envolvidos ao longo da vida útil estimada do produto. Do ponto de vista econômico, é muito importante quando se projeta um componente que consegue resistir por mais tempo às condições 
adversas. Assim, embora não seja possível evitar a corrosão, pode-se aumentar a vida útil dos equipamentos, a qual seria menor caso não houvesse estudos para o aprimoramento dos materiais tornando-os mais resistentes e o desenvolvimento de métodos mais eficientes de proteção contra a corrosão.

\subsubsection{Corrosão do aço-carbono em água do mar}

A água do mar é o meio onde o cloreto de sódio esta presente com uma concentração em torno de 3,5\%. Outra característica é que seu pH está em torno de 7 e a condutividade média de $3000 \mathrm{~S} . \mathrm{m}^{-1}$. Essas características permitem que a água do mar seja considerada um eletrólito agressivo. A taxa de corrosão vai depender do metal exposto, aeração, temperatura e quantidade de microorganismos presentes no meio. Portanto, estruturas de aço-carbono submersas em meios com $\mathrm{NaCl}$ estão sempre sujeitas a elevadas taxas de corrosão, como estacas de piers, tubulações submersas, embarcações, âncoras, plataformas de extração de petróleo, dentre outras (NUNES, 2007; SHREIR, 1994).

A Figura 2.3 apresenta âncoras de barcos de pescadores que foram expostas ao ambiente marinho deixando evidente a agressividade desta atmosfera nestes objetos. Assim, a intensidade da corrosão depende tanto da umidade quanto da quantidade de sais presentes em suspensão. Em atmosfera marinha estas condições são muito favoráveis e assim o aço-carbono atinge níveis de corrosividade elevados (NUNES, 2007).

Segundo a literatura a perda de espessura do aço-carbono em meio de água do mar varia entre $0,12 \mathrm{~mm}$ por ano a 0,060 $\mathrm{mm}$ por ano. Esta variação é devido a diversos fatores, como por exemplo: temperatura, hidrodinâmica do meio, profundidade de exposição e quantidade de oxigênio dissolvido (LAQUE, 1948 apud SHREIR, 1994; CORROSÃO, 2008). 


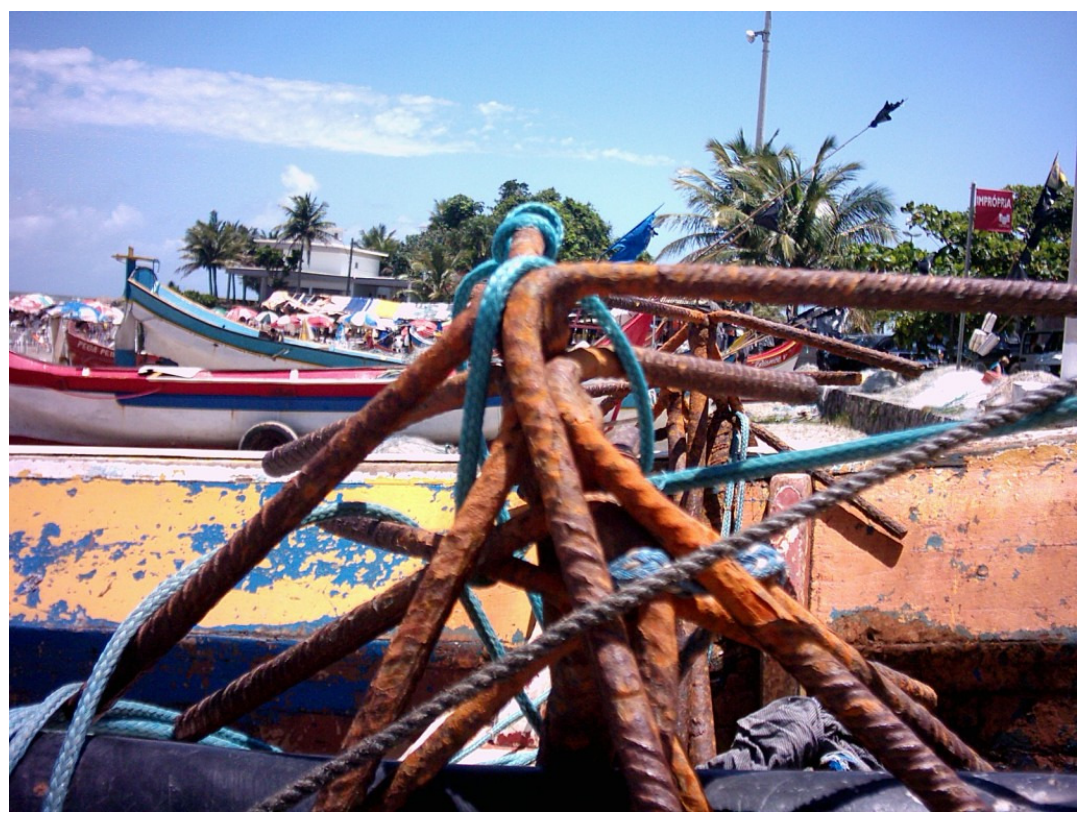

Figura 2.3 - Âncora de barco de pescador.

Quando o aço é exposto em meio natural com ou sem $\mathrm{NaCl}$ ou levemente ácido, no produto de corrosão formado sobre a superfície do metal sempre haverá a presença do íon cloreto agindo como um catalisador no processo de formação do $\beta$ $\mathrm{FeOOH}$. Logo, o $\mathrm{Cl}^{-}$poderá migrar para a interface óxido-superfície do metal, acelerando assim a velocidade de dissolução do metal (LI et al., 2007).

\subsection{Inibidores de corrosão}

Inibidores de corrosão são substâncias ou mistura de substâncias que adicionadas ao meio corrosivo têm o objetivo de evitar, prevenir ou impedir o desenvolvimento das reações de corrosão do metal exposto, sejam nas fases gasosas, aquosas ou oleosas (BRETT, 1993; DILLON, 1997; UHLIG, 1948).

Diversas são as aplicações industriais nas quais são utilizados os inibidores de corrosão, podendo-se destacar o setor de autopeças e metalurgia (na preservação das partes externas dos componentes), a construção civil (prevenindo o ataque por cloretos a estruturas de aço), os minério-dutos, sistemas de refrigeração 
e aquecimento (prevenindo a corrosão das paredes dos equipamentos) e, sobretudo, a indústria de petróleo e gás (DILLON, 1997; SPELLER, 1930).

Os inibidores de corrosão podem funcionar pela sua adsorção na superfície do metal, aumentando ou diminuindo o potencial de corrosão, e a combinação do inibidor adsorvido juntamente com o acumulo dos produtos de corrosão pode produzir um filme passivo sobre a superfície do metal (DILLON,1997; SASTRI, 1998).

A eficiência de uma determinada quantidade de inibidor adicionada ao meio pode ser alta para um metal em particular, em um determinado meio agressivo, com certa quantidade de oxigênio dissolvido, temperatura e tempo, porém qualquer mudança nas características do meio pode não somente reduzir esta eficiência como também aumentar a velocidade da corrosão (SASTRI, 1998; UHLIG, 1948).

Portanto, a aplicação adequada do uso de inibidores de corrosão é uma medida preventiva contra o ataque corrosivo nos materiais metálicos e para que sua aplicação seja satisfatória, devem ser consideradas fundamentalmente as causas da corrosão no sistema, os mecanismos de ação dos inibidores utilizados, o impacto causado ao meio ambiente e os custos que podem ser minimizados com sua utilização.

Na década de 20 os produtos utilizados como inibidores de corrosão eram praticamente inócuos. Contudo, no início da década de 30 foi introduzido o uso de cromato como inibidor de corrosão com o intuito de reduzir a velocidade de corrosão dos metais (SPELLER, 1930, 1935).

Visando reduzir os impactos ambientais, a partir da década de 1980, o uso do cromato como inibidor de corrosão foi sendo utilizado com muitas restrições devido a sua alta toxidez. Este movimento favoreceu ainda mais o desenvolvimento e o estudo de novos produtos não-tóxicos e compatíveis com o meio ambiente. Algumas empresas, principalmente as de pequeno e médio porte, ainda continuam usando este produto, sendo que nas regiões de São Paulo e Rio de Janeiro existem registros de uso de 600 a 1000 ppm de cromato em seus sistemas de refrigeração (MAINIER; MARQUES, 1991 apud MAINIER; SILVA, 2004). 


\subsubsection{Classificação dos inibidores}

Os inibidores de corrosão podem ser classificados quanto ao mecanismo de ação, podendo ser anódico, catódico ou misto; quanto à sua composição (orgânicos ou inorgânicos), ainda quanto a sua forma, isto é em solução, dispersão ou em fase gasosa (GUEDES, 1996; SASTRI, 1998; UHLIG, 1948).

Inibidores Anódicos: os inibidores classificados como anódicos atuam reprimindo as reações anódicas de dissolução do metal, isto é, retardando ou impedindo as reações de oxidação. Este inibidor poderá ser ou não formador de filme passivante. Para se conseguir uma proteção ideal do metal, é necessário que a substância usada como inibidor de corrosão seja adicionada ao meio corrosivo em quantidade adequada, além da necessidade de manter a concentração do meio corrosivo uniforme. Se a quantidade do inibidor adicionada ao meio não for ideal e não for uniforme em todo o meio corrosivo e sobre toda a extensão da superfície metálica, o filme formado não será uniforme, o que possibilitará a corrosão localizada nas regiões não-protegidas. Logo, se não houver a formação de um filme sobre toda a superfície metálica, poderá ocorrer processo de corrosão por pite. Entre os inibidores anódicos mais utilizados destacam-se os cromatos, nitritos, molibdatos e tungstatos. (GENTIL,1983; GUEDES, 1996).

Os inibidores anódicos deslocam o potencial de corrosão do metal para valores mais positivos. Na Figura 2.4 é mostrado o comportamento de um inibidor anódico, ou seja, é possível observar que o potencial de corrosão foi deslocando para um valor mais positivo. 


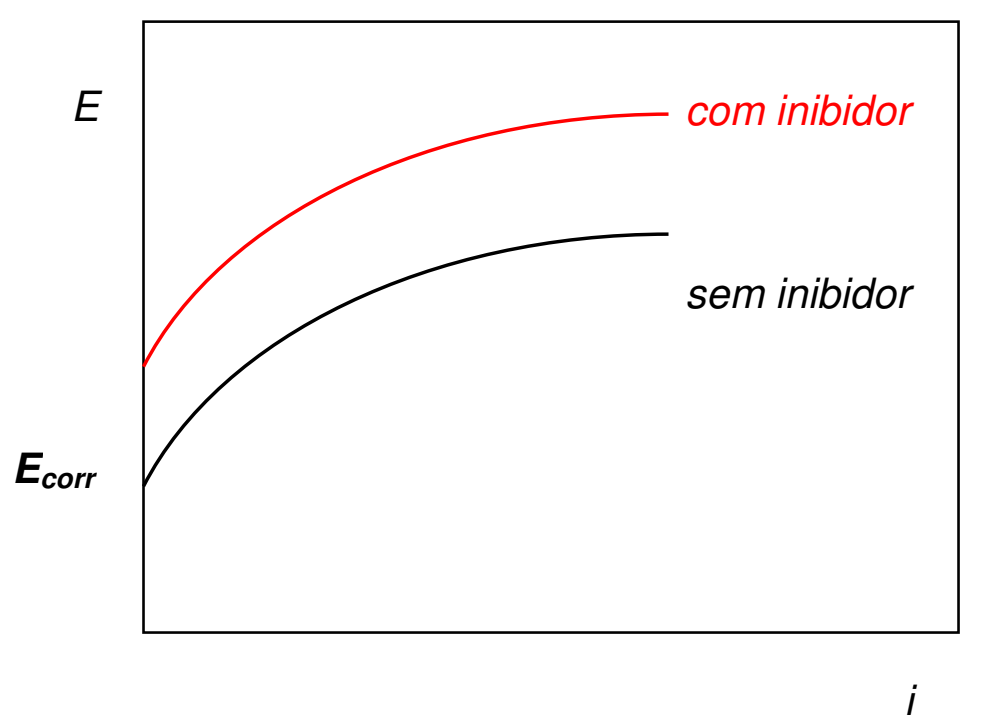

Figura 2.4 - Representação gráfica do efeito do inibidor anódico

Inibidores Catódicos: os inibidores catódicos agem inibindo ou impedindo as reações catódicas. As substâncias que agem como inibidores catódicos podem fornecer íons metálicos que reagem com os íons hidroxilas $\left(\mathrm{OH}^{-}\right)$presentes no meio. Esses compostos dão origem a uma película impermeável na área catódica e, assim impedem a difusão do oxigênio ou a redução do cátion hidrogênio, inibindo desta forma o processo catódico.

Geralmente os inibidores catódicos são substâncias que aumentam o pH do meio, dentre elas os bicarbonatos, hidróxido de zinco, magnésio e níquel. Os inibidores catódicos alteram o potencial de corrosão para valores mais negativos (GENTIL,1983; GUEDES, 1996). Na Figura 2.5 é mostrado o comportamento de um inibidor catódico, ou seja, é possível observar que o potencial de corrosão foi deslocando para um valor mais negativo. 


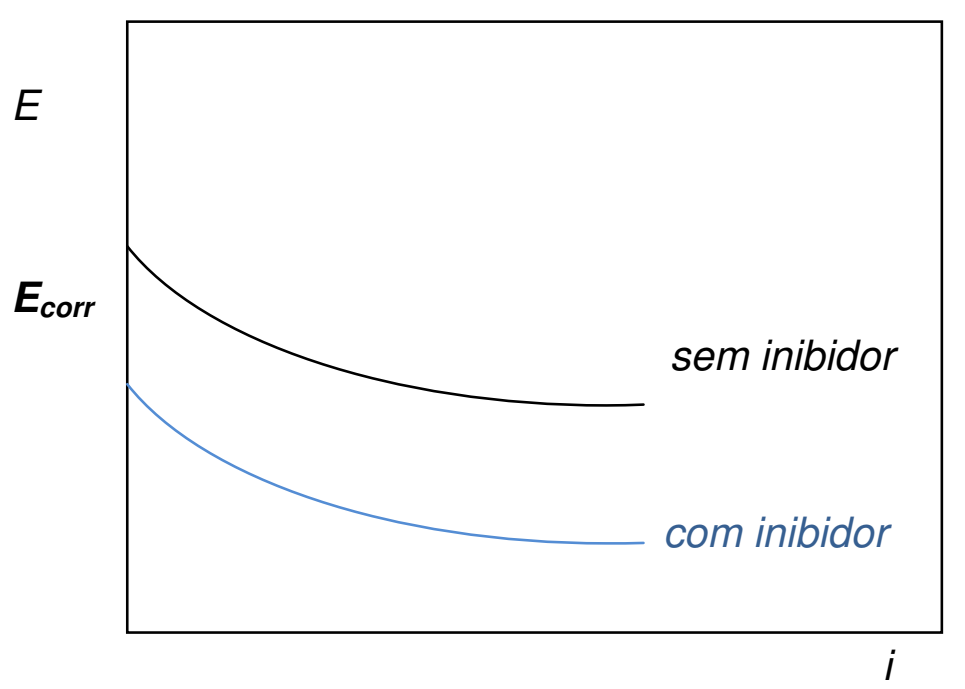

Figura 2.5 - Representação gráfica do efeito do inibidor catódico

Inibidores Mistos: os inibidores mistos agem inibindo tanto as reações anódicas de dissolução como as reações catódicas. Estes inibidores agem pela sua adsorção na superfície do metal, originando um filme impermeável e uniforme, responsável pela alteração tanto das curvas de polarização anódicas quanto das curvas de polarização catódicas. Esse processo resulta em uma variação muito pequena no potencial de corrosão (GENTIL,1983; GUEDES, 1996). Na Figura 2.6 é mostrado o comportamento de um inibidor misto, ou seja, é possível observar que as curvas de polarização anódicas e catódicas foram polarizadas em relação à curva obtida na ausência do inibidor.

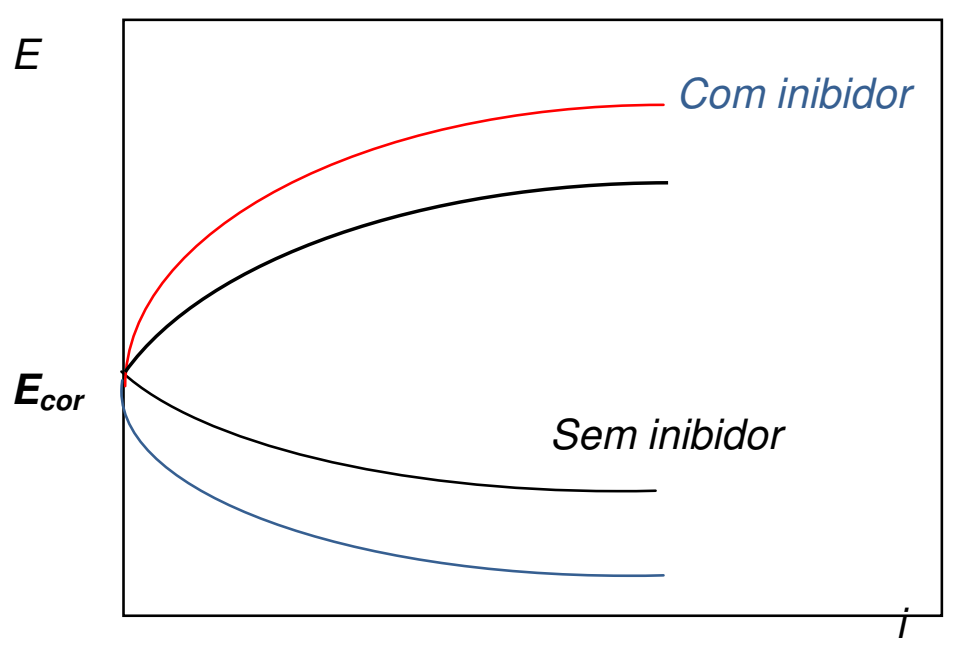

Figura 2.6 - Representação gráfica do efeito do inibidor misto 
Os inibidores classificados como anódicos, catódicos ou mistos podem ser de composição orgânica ou inorgânica.

Inibidores orgânicos: as substâncias orgânicas que agem como inibidores de corrosão possuem grupos fortemente polares e agem através de sua adsorção na superfície metálica. A adsorção de moléculas orgânicas ocorre pois a força de interação entre o inibidor e a superfície do metal é maior que a força de interação entre as moléculas de água e a superfície do metal. Os inibidores orgânicos fazem parte de uma classe muito ampla de substâncias. Entre as substâncias orgânicas que agem como inibidores efetivos para o ferro e suas ligas, destacam-se as aminas alifáticas e aromáticas que são compostos a base de nitrogênio, tiouréia e seus derivados, compostos contendo átomo de enxofre e vários aldeídos, que são compostos com átomo de oxigênio (TABANELLI, 1987 apud GUEDES, 1996; WEST, 1970 apud GUEDES, 1996).

Inibidores inorgânicos: as substâncias inorgânicas que são capazes de inibir a corrosão são classificadas como inibidores inorgânicos. O mecanismo de ação dos inibidores inorgânicos pode ser pela inibição das reações de oxidoredução (reações anódicas, catódicas ou ambas), formadores de filme protetor ou até por adsorção na superfície do metal. Dentre os inibidores inorgânicos os principais são os fosfatos e o cromato (TRABANELLI, 1987 apud GUEDES, 1996; WEST, 1970 apud GUEDES, 1996).

\subsubsection{Processos de adsorção dos inibidores}

Os processos de adsorção dos inibidores são influenciados pela natureza, pela carga na superfície do metal, pela estrutura química do inibidor, além da agressividade do meio que irá influenciar principalmente nas características da superfície do metal. Em meios ácidos, o inibidor é adsorvido na superfície metálica livre de óxidos e impede as reações de evolução de hidrogênio nos sítios catódicos, porém, em meios neutros o inibidor aumenta as qualidades protetoras do filme de 
óxido (camada passiva) impedindo a ação dos íons agressivos. As principais interações entre o adsorbado (substância adsorvida - inibidor) e o adsorvente (superfície metálica) são a adsorção física e a quimissorção (GUEDES, 1996).

Adsorção física: a adsorção física, ou de van der Waals, é um processo rápido e decorre da ação de forças de atração intermoleculares fracas entre o adsorvente e as moléculas adsorvidas, sendo a ordem de grandeza das energias de entalpias de reação de $20 \mathrm{~kJ} \mathrm{~mol}^{-1}$ (GOMIDE, 1988; ARIOLDI; FARIAS, 2000). O inibidor que se adsorve fisicamente na superfície do metal pode também ser removido com maior facilidade (GUEDES, 1996).

Quando o inibidor de corrosão é adicionado ao sistema metal-meio, ocorre adsorção das moléculas do inibidor, gerando uma diferença de potencial entre o eletrodo metálico e a solução, em razão da redistribuição das cargas elétricas na interface metal-solução não ser uniforme. Esta distribuição das cargas através da interface é denominada de dupla camada elétrica. A Figura 2.7 mostra uma representação esquemática da dupla camada elétrica.

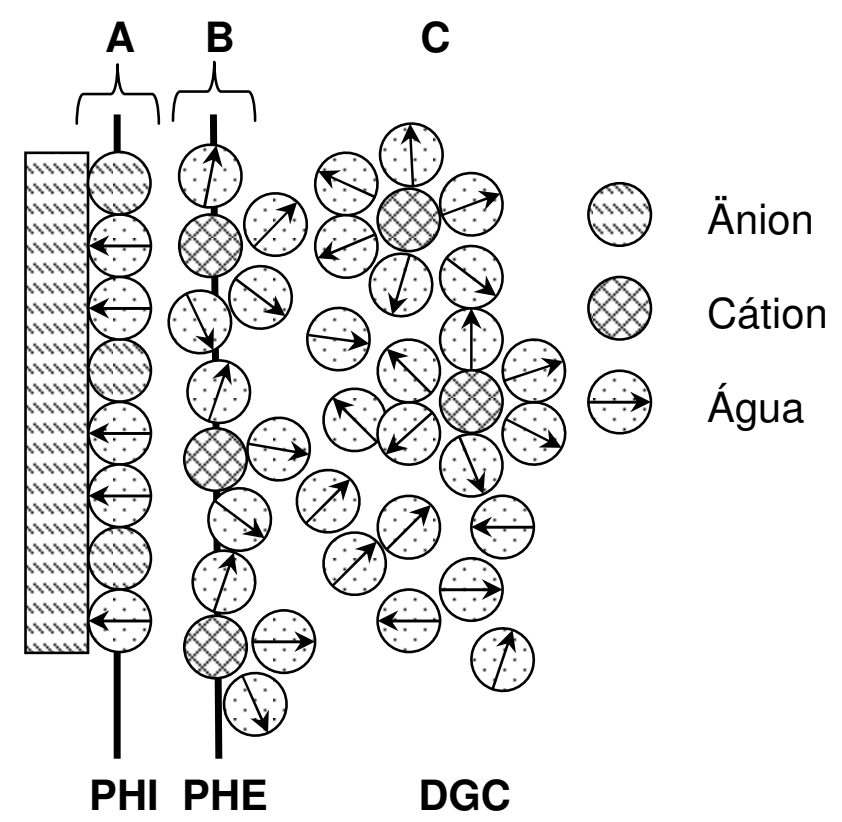

Figura 2.7 - Representação esquemática da dupla camada elétrica (fonte: SASTRI, 1998).

A região A é formada especialmente por íons adsorvidos na superfície metálica e o lugar geométrico localizado no centro dessas cargas é denominado de 
plano interno de Helmholtz (PHI) da dupla camada elétrica. As cargas são balanceadas em parte pelos íons hidratados de cargas opostas oriundos do plano externo de Helmholtz (PHE), localizado na região $B$ da Figura 2.7. Na região $C$ encontra-se a camada difusa Guoy-Chapman (DGC), onde a concentração dos íons hidratados diminui em direção ao centro do eletrolítico e assim o balanço final das cargas se fecha na superfície metálica (SASTRI, 1998).

$\mathrm{Na}$ adsorção física não ocorre a quebra ou a realização de nenhuma ligação química, logo a natureza química do adsorbato (inibidor) é inalterada. Se a diferença

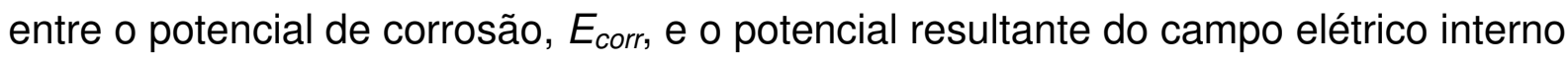
de Helmholtz, denominado potencial de carga nula, $E=0$, resultar em um valor positivo ocorre o favorecimento da adsorção de ânions, no entanto se essa diferença for negativa, tem-se um favorecimento da adsorção do cátion (TRABANELLI, 1993).

A adsorção eletrostática depende das características elétricas dos inibidores orgânicos, do valor do potencial de corrosão em relação ao potencial de carga nula e do tipo de ânions adsorvidos presentes no meio corrosivo. Outros fatores que alteram o grau de inibição são o comprimento da cadeia carbônica, a natureza e posição dos anéis aromáticos substituintes (TRABANELLI, 1987).

Adsorção química: A adsorção química, também conhecida como quimissorção ou adsorção ativada, resulta de uma interação muito mais intensa entre a substância adsorvida e o sólido adsorvente. Embora a intensidade da ligação varie consideravelmente de um caso para outro, é certo que forças de valência têm participação neste processo, sendo a ordem de grandeza das energias de entalpias de reação de $25 \mathrm{~kJ} \cdot \mathrm{mol}^{-1}$ a $500 \mathrm{~kJ} . \mathrm{mol}^{-1}$, alto valor de energia envolvida, fato que também permite concluir que a adsorção ativada é um processo lento a baixas temperatura, como por exemplo, a temperatura ambiente.

Uma substância pode ser adsorvida fisicamente num determinado sólido a baixas temperaturas, havendo quimisorção no mesmo adsorvente em temperatura mais alta. Em temperaturas intermediárias os dois processos poderão ocorrer simultaneamente (GOMIDE, 1988; ARIOLDI; FARIAS, 2000).

Uma das maneiras de diferenciar a adsorção química da adsorção física é a variação de energia livre do sistema. A literatura mostra que valores até $25 \mathrm{kcal} \mathrm{mol}^{-1}$ 
o processo ainda é considerado como sendo uma adsorção física, já para valores superiores considera-se como adsorção química (SASTRI, 1998).

\subsection{Controle da corrosão pelo uso de inibidores de corrosão}

A água é uma das substâncias mais usadas em plantas químicas e o seu contato com os equipamentos constituídos por aço-carbono, como por exemplo, os equipamentos dos sistemas de refrigeração, bombas e tubulações é um processo comum (PATTON, 1993; FREEDMAN, 1986).

A presença de sais e principalmente de cloretos nas águas naturais acabam por acelerar a corrosão do aço-carbono, isto é, aumentam a condutividade da água e influenciam nas características da camada de óxidos e/ou hidróxido, tornando-a menos protetora. Assim, o uso do aço-carbono em meio aquoso deve estar atrelado a algum tipo de proteção contra a corrosão. O controle da corrosão vai desde o uso de inibidores, biocidas, sequestrantes de oxigênio, à aplicação de revestimento interno e proteção catódica. Existem várias razões para ser feito o controle da corrosão, podendo-se destacar o aumento da vida útil dos equipamentos, a redução da geração de sólidos suspensos e o controle da poluição ambiental proveniente de danos nas tubulações e vazamentos (PATTON, 1993).

$\mathrm{Na}$ indústria petrolífera, por exemplo, o uso de inibidores de corrosão proporciona boa proteção contra a corrosão tanto na produção como no refino do petróleo, favorecendo a conservação de equipamentos e evitando prejuízos operacionais (MAINIER, 1996 apud MAINIER; SILVA, 2004). 


\subsubsection{Molibdato e Tungstato}

O molibdato $\left(\mathrm{MoO}_{4}{ }^{4-}\right)$ e o tungstato $\left(\mathrm{WO}_{4}{ }^{2-}\right)$ são oxiânions de molibdênio (Mo) e de tungstênio (W), respectivamente. O molibdênio e o tungstênio são elementos químicos metálicos do bloco $d$ (elementos de transição) e pertencentes ao grupo do cromo. O Mo, como o cromo $(\mathrm{Cr})$, apresenta configuração eletrônica $d^{5}$ $s^{1}$, com uma configuração $d^{5}$ semi preenchida estável; já o $\mathrm{W}$ tem configuração $d^{4} s^{2}$. O número de oxidação do Mo e do $\mathrm{Cr}$ pode variar de $(+\mathrm{I})$ a $(+\mathrm{VI})$, e para o $\mathrm{W}$ de (+II) a $(+\mathrm{VI})$. Diferentemente do $\mathrm{Cr}$, o estado de oxidação $(+\mathrm{VI})$ para o Mo e para o W é o mais estável, e o estado (+III) é fortemente redutor. O W e Mo são semelhante em tamanho e em propriedades químicas. O principal óxido do estado de oxidação (+VI) para o $\mathrm{Mo} \mathrm{e} \mathrm{W}$ é $\mathrm{MoO}_{3}$ e $\mathrm{WO}_{3}$. $\mathrm{OMoO}_{3}$ e $\circ \mathrm{WO}_{3}$ são fortemente ácidos, e se dissolvem em $\mathrm{NaOH}$ aquoso, formando tetraedros discretos dos íons molibdato $\left(\mathrm{MoO}_{4}{ }^{2-}\right)$ e tungstato $\left(\mathrm{WO}_{4}{ }^{2-}\right)$ respectivamente (LEE, 1980).

O molibdênio e o tungstênio são freqüentemente adicionados em ligas ferrosas e na forma de oxiânions apresentam aplicações como inibidores de corrosão (ROBERTSON, 1951; SAKAXHITA; SATO, 1977; VUKASOVICH; FARR, 1986; YUCHUM et al., 2002).

\subsubsection{Aplicação do molibdato de sódio como inibidor de corrosão}

Uma das vantagens do uso do molibdato de sódio como inibidor da corrosão é a sua baixa toxidez. Para avaliar sua eficiência como inibidor e compreender seu mecanismo de atuação vários autores vem estudando sua aplicação como inibidor da corrosão para o ferro e suas ligas. Portanto, a literatura é rica em trabalhos desenvolvidos com a presença de molibdato como inibidor de corrosão para diferentes meios e metais. Alguns dos trabalhos desenvolvidos estão relacionados a seguir.

Em 1986 foi feita uma revisão sobre alguns estudos publicados referentes às propriedades físicas e químicas do molibdato enfatizando as vantagens ambientais de seu uso (baixa toxidade) e aplicações práticas. O molibdênio é estável e 
permanece na forma tetraédrica Mo (IV) em solução neutra e alcalina, polimeriza a $\mathrm{Mo}_{7}$ e $\mathrm{Mo}_{8}$ em soluções ácidas. De uma perspectiva ambiental, os estatutos e regulamentações ambientais não apresentam parâmetros mínimos e os estudos realizados até a época, em geral, não demonstraram toxidez do molibdênio. Sobre as aplicações práticas como inibidor de corrosão, segundo o estudo, o molibdato foi inicialmente utilizado como pigmento de tintas e muito depois como inibidor de corrosão. Dentre as aplicações como inibidor se destacou: o uso para a anodização do alumínio; em meio de águas de refrigeração; como elemento de liga; e em fluído refrigerante e siderúrgico substituindo o uso de amina e do nitrato.

Outros estudos também analisados na época apresentavam numerosas substâncias que, através do sinergismo com o molibdênio aumentam a eficiência de inibição, como a combinação do molibdato com o triazol e molibdato com o cromato utilizado para proteger materiais ferrosos e não ferrosos, entre outras combinações. $O$ estudo não encontrou evidências que $O$ molibdênio modifique a cinética da dissolução dos metais. A inibição ocorre pela formação de um filme insolúvel com o Fe (III), reduzindo a densidade de corrente de passivação. Pelo estudo foi observado que a inibição catódica do Mo (IV) é fraca, sendo o molibdênio (ou em sua forma de composto molibdato) considerado um inibidor anódico. O molibdado também inibiu a corrosão por pite adsorvendo-se nas paredes do pite e promovendo a sua repassivação através da transferência de ânions da superfície do filme para o centro do pite (VUKASOVICH, FARR, 1986).

Também em 1986, Bentley e colaboradores (1986) discutiram os mecanismos da inibição da corrosão pelo molibdato através de estudos já publicados até a época. Verificou-se que o molibdato pode promover a formação de um filme protetor nos sítios anódicos, ou seja, passivando o metal, e assim reduzindo a densidade de corrente de passivação e de transpassivação. Os autores fizeram algumas avaliações em torno do mecanismo de inibição pelo molibdato em meio com íons agressivos, tais como $\mathrm{Cl}^{-}$e $\mathrm{SO}_{4}{ }^{2-}$, e verificaram que a concentração de molibdato é maior nas proximidades da superfície metálica, sugerindo que o molibdato é atraído pelos óxidos do metal, logo formando um filme nos sítios anódicos. Os autores concluíram que este comportamento ocorre em virtude do 
molibdato reagir com os íons oxidados até a neutralização formando o composto de ferro-molibdato.

Saremi, Dehghanian e Sabet (2006) estudaram dois importantes fatores quanto à inibição da corrosão do aço doce que foram: o efeito hidrodinâmico e a variação da concentração de molibdato no meio para inibir a corrosão do açocarbono em água de refrigeração simulada. Para este estudo foram realizados experimentos de curvas de polarização potenciodinâmica e espectroscopia de impedância eletroquímica. As curvas de polarização potenciodinâmicas mostraram que o aumento da concentração de molibdato reduz a velocidade das reações de dissolução do aço doce. Os diagramas de Nyquist mostraram que a resistência de transferência de carga aumenta com a presença do íon molibdato em solução. Os resultados sugeriram que o molibdato reduz a taxa de corrosão do aço doce em água de resfriamento simulada, porém a sua performance como inibidor da corrosão em sistemas de resfriamento tem um limite ótimo que depende da agressividade da concentração dos íons, enquanto que o efeito hidrodinâmico pode melhorar a eficiência da inibição do molibdato através do transporte do oxigênio e do íon molibdato em direção a superfície do eletrodo. Também pode ser quimicamente adsorvido e auxiliar na produção de um composto químico protetor tal como o molibdato de ferro. No entanto, segundo os autores ainda não existe um modelo compreensível para elaborar um mecanismo de inibição do molibdato em meio neutro ou em meio alcalino, mas maiores taxas de rotação do eletrodo podem ter um efeito adverso na eficiência da inibição.

Em meio de água natural é comum a presença do íon $\mathrm{Cl}^{-}$, proveniente da dissociação e dissolução do sal $\mathrm{NaCl}$. Muitos grupos de pesquisa também vêm trabalhando já há alguns anos com o estudo da inibição da corrosão do ferro e suas ligas em meio de $\mathrm{NaCl}$ pela utilização do molibdato de sódio. Em 1977, foram estudadas as propriedades da seletividade iônica do filme precipitado de óxido/hidróxido de ferro com e sem o íon $\mathrm{MoO}_{4}{ }^{2-}$ e molibdato férrico em solução de $\mathrm{NaCl}, \mathrm{KCl}, \mathrm{MgCl}_{2}, \mathrm{BaCl}_{2}, \mathrm{AlCl}_{3}$ e $\mathrm{FeCl}_{3}$. Os resultados obtidos por medida de potencial indicaram que a corrosão do ferro é acelerada pela presença do ín $\mathrm{Cl}^{-}$no filme, o qual pode diminuir o pH local e provocar uma difusão dos cátions e assim 
propiciar a seletividade iônica do filme. A adsorção dos íons de $\mathrm{MoO}_{4}{ }^{2-}$ no óxido altera a seletividade do íon no filme precipitado, isto é, do ânion para o cátion em solução de $\mathrm{NaCl}$ e $\mathrm{KCl}$. Esta seletividade pelo cátion do filme inibiu a corrosão do ferro, pois os íons de $\mathrm{H}^{+}$difundem para fora do filme. $\mathrm{O}$ efeito dos íons $\mathrm{MoO}_{4}{ }^{2-}$, como inibidor de corrosão, seria reduzido somente na presença de cátions multivalentes (SAKAXHITA; SATO,1977).

Dentre os produtos não-tóxicos conhecidos, Shams e Wang (1996) estudaram $\circ \mathrm{Na}_{2} \mathrm{MoO}_{4}$ (molibdato de sódio), como inibidor de corrosão para o aço doce em meio de $\mathrm{NaCl}$ e $\mathrm{Na}_{2} \mathrm{SO}_{4} \mathrm{com}$ o $\mathrm{pH}$ tendendo a neutralidade. Para monitorar o comportamento eletroquímico do sistema metal-solução, os autores utilizaram técnicas de monitoramento do potencial de corrosão. Para avaliar a superfície do metal, foi usada a análise por fluorescência de raios $X$. Neste estudo foi concluído que a eficiência do $\mathrm{Na}_{2} \mathrm{MoO}_{4}$ como inibidor de corrosão para o aço doce é influenciada pelo tempo, temperatura, aeração do sistema e concentração de $\mathrm{NaCl}$ e $\mathrm{Na}_{2} \mathrm{SO}_{4}$ cujo metal é exposto. A observação por fluorescência de raios $X$ da superfície do metal permitiu-lhes identificar que o filme formado com molibdato de sódio não apresenta uniformidade sobre o metal.

Em 2000, Virtanen, Surber e Nylund estudaram a influência do molibdato de sódio na resistência a corrosão por pite do ferro em meio de $\mathrm{NaCl}$ desaerado e tamponada com borato a pH 8,4. Para monitorar o comportamento eletroquímico do sistema metal-solução, os autores utilizaram a técnica de polarização potenciodinâmica com velocidade de varredura de $0,2 \mathrm{mV} \cdot \mathrm{s}^{-1}$. Para avaliarem a superfície do metal eles utilizaram a técnica de microscopia eletrônica de varredura, analises de raios $X$ por energia dispersiva (EDX) e difração de raios $X(X R D)$. Os autores observaram que o molibdato possui a característica de repassivar o ferro, mesmo na ocorrência de um pequeno pite metaestável. Com este estudo foi constatado que a superfície passivada pelo molibdato forma com o ferro um sal de $\mathrm{FeMoO}_{4}$, contribuindo para aumentar à resistência a corrosão por pite, principalmente pelo mecanismo da adsorção competitiva com o íon cloreto. Os autores sugerem que a inibição seria mais eficiente com a presença do molibdato na liga, o que evitaria o pite (VIRTANEN; SURBER; NYLUND, 2000). 
A literatura também nos fornece resultados dos trabalhos nos quais alguns autores estudaram a compatibilidade do molibdato com outras substâncias já testadas como inibidores de corrosão. Yuchum e colaboradores (2002) estudaram a compatibilidade entre o molibdato e o fosfato para inibir a corrosão do aço-carbono em meio neutro. Como meio eletrolítico foi utilizado água do sistema municipal de distribuição, a concentração do molibdato foi variada de 0 a $1000 \mathrm{mg} \cdot \mathrm{L}^{-1}$. Para monitorar o comportamento eletroquímico do sistema metal-solução, os autores utilizaram técnicas técnica de polarização potenciodinâmica com velocidade de varredura de $5 \mathrm{mV} \cdot \mathrm{s}^{-1}$. Eles concluíram que a evolução da inibição da corrosão do aço pelo molibdato é linear com a concentração, e a eficiência de inibição é superior quando ao meio corrosivo é adicionado o fosfato em conjunto com o molibdato. A melhor concentração da mistura encontrada foi de $250 \mathrm{mg} \cdot \mathrm{L}^{-1}$ de molibdato e $125 \mathrm{mg} \cdot \mathrm{L}^{-1}$ de fosfato. A razão possível para explicar o mecanismo de inibição da mistura molibdato e fosfato é a existência de um sinergismo entre as moléculas e a formação de uma camada passiva sobre o metal provocada pelo fosfato.

Vukasovich e Robitaille (1977) estudaram a taxa da corrosão do aço AISI 1010 em meio de água simulada de refrigeração, com durezas diferentes, na presença e ausência do molibdato. As taxas foram obtidas através de ensaios de perda de massa. $\mathrm{O}$ meio foi preparado com $25 \mathrm{mg} \cdot \mathrm{L}^{-1}$ de $\mathrm{Na}_{2} \mathrm{CO}_{3}, 170 \mathrm{mg} \cdot \mathrm{L}^{-1}$ de $\mathrm{NaHCO}_{3}, 520 \mathrm{mg} \cdot \mathrm{L}^{-1}$ de $\mathrm{SO}_{4}{ }^{-2}, 250 \mathrm{mg}^{-L^{-1}}$ de $\mathrm{Cl}^{-}$e $\mathrm{CaCO}_{3}$ com concentrações variando de acordo com o grau de dureza, de $15 \mathrm{mg} . \mathrm{L}^{-1}$ a $200 \mathrm{mg} \cdot \mathrm{L}^{-1}$, ou seja, de água levemente dura a moderadamente dura. Neste estudo, os autores também avaliaram a influência na velocidade da corrosão do aço com o aumento da concentração dos íons $\mathrm{SO}_{4}^{-2}$ e $\mathrm{Cl}^{-}$no meio com e sem o molibdato, além de avaliar a inibição cooperativa e o sinergismo do molibdato com outros inibidores, sendo eles o MBT (mecarptobenzotiazol), BT (1,2,3-benzotriazol), TT (tolitriazol), HEDP (1hidroxietano-1,1-difosfónico), AMP (ácido amino metileno fosfônico), HX (hexametafosfato de sódio), nitrito de sódio, inibidores catódicos (sulfato de zinco e sulfato de manganês), um silicato $\left(\mathrm{SiO}_{2} 28,7 \%, \mathrm{Na}_{2} \mathrm{O}\right.$ 8,9\%) e alguns inibidores orgânicos. Os resultados apontaram que o meio de água moderadamente dura (mais que $200 \mathrm{mg} \cdot \mathrm{L}^{-1}$ de $\mathrm{CaCO}_{3}$ ) a velocidade de corrosão é menor que no meio de água com baixa dureza (15 mg. $\mathrm{L}^{-1}$ de $\mathrm{CaCO}_{3}$ ), porém, adicionando-se $250 \mathrm{mg} \cdot \mathrm{L}^{-1}$ de 
molibdato de sódio na água, a taxa de corrosão do aço é reduzida, independente da dureza da água.

Os autores também verificaram que a taxa de corrosão aumenta com o aumento da concentração de $\mathrm{SO}_{4}^{-2} \mathrm{e} \mathrm{Cl}^{-}$no meio e, mesmo na presença de grande quantidade destes íons na solução, o molibdato reduz a velocidade de corrosão do aço. A avaliação da inibição cooperativa do molibdato com outros inibidores mostrou que a velocidade da corrosão do aço é reduzida adicionando-se ao meio de água moderadamente dura o TT, porém a velocidade aumenta com o MBT. A inibição cooperativa do molibdato e HEDP foi realizada com o TT, BT e MBT e os resultados mostraram que o TT é menos eficiente, enquanto com o BT é mais eficiente em relação aos três inibidores avaliados. Também foi comparada a inibição cooperativa do molibdato com HX, AMP e HEDP em meio de água moderadamente dura, os resultados mostraram que o $\mathrm{HX}$ é mais eficiente que os três avaliados. Em meio de água dura, o nitrito de sódio age em conjunto com o molibdato. Os resultados dos três inibidores catódicos estudados mostraram que o sulfato de zinco é o mais eficiente, e o silicato é o menos eficiente. $O$ estudo dos inibidores orgânicos mostrou que o gluconato de sódio produz a maior redução da corrosão e o succinato de sódio, benzoato de sódio e o morfolino também reduzem a corrosão, apesar de serem menos eficientes. Os dicarboxilato, tricarboxilato e o sarcosino de sódio aumentam a velocidade da corrosão. Com os resultados os autores concluíram que o sinergismo dos inibidores pode ocorrer, porém depende de sua composição química e das condições corrosivas.

Farr e Saremi (1982) estudaram a mistura do molibdato com o citrato e com o fosfato quanto à eficiência como inibidores da corrosão do aço SAE 1010, em meio simulando a água de refrigeração com e sem $\mathrm{Ca}^{+2}$. Neste estudo os autores utilizaram as técnicas de polarização potenciodinâmica e espectroscopia de Emissão Auger (emissão de um elétron de Auger) para a análise química da superfície do aço depois de polarizado. A velocidade de varredura para a polarização foi de $0,2 \mathrm{mV} . \mathrm{s}^{-1}$ e o tempo de pré-imersão variou entre 90 minutos a vinte quatro horas. A espectroscopia de Auger foi capaz de analisar pontualmente áreas com diâmetro menor que $10 \mu \mathrm{m}$, próprio para análise de pites. O meio simulando a água de refrigeração sem $\mathrm{Ca}^{+2}$ foi preparado com 304 ppm de $\mathrm{NaCl}$, 352 ppm de $\mathrm{Na}_{2} \mathrm{SO}_{4}$, 
128 ppm de $\mathrm{NaHCO}_{3}$ e 14 ppm de $\mathrm{Na}_{2} \mathrm{CO}_{3}$. Para o meio com $\mathrm{Ca}^{+2}$ foi utilizado 304 ppm de $\mathrm{Ca}_{2} \mathrm{Cl}, 352$ ppm de $\mathrm{CaSO}_{4}$ e 300 ppm de $\mathrm{Ca}(\mathrm{OH})_{2}$, para as duas soluções o $\mathrm{pH}$ foi variado de 8,5 a 11 .

Os experimentos mostraram que o molibdato $(500 \mathrm{ppm})$ com o citrato (1450 ppm) inibem a corrosão do metal em meio com $\mathrm{Ca}^{+2}$, sendo que em pH 11 a inibição foi maior que em pH 8,5. Também foi evidenciado que o fosfato acelera a corrosão do aço, porém quando adicionado ao meio sem $\mathrm{Ca}^{+2}$ o potencial de corrosão é aumentado e a densidade de corrente de corrosão é reduzida. Porém, em meio com pH maior que 10 a adição de fosfato no molibdato torna menor a eficiência de inibição da corrosão da mistura. Para o meio sem $\mathrm{Ca}^{+2}$, $\mathrm{pH}$ alto e com a adição de molibdato, citrato e fosfato, a eficiência aumenta. A espectroscopia detectou, para todos os sistemas analisados, a presença do íon molibdênio nos pites. Com os resultados os autores puderam concluir que em meio simulando a água de refrigeração e com $3,1.10^{-3} \mathrm{~mol}^{-\mathrm{L}^{-1}}$ de $\mathrm{MoO}_{4}{ }^{2} \mathrm{o}$ íon molibdato adsorve-se no filme de óxido formado sobre o aço SAE 1010, induzindo e melhorando a passivação destas áreas. Contudo, em densidade de corrente alta este filme é menos protetor. Eles também concluíram que, devido à insuficiência do oxigênio nos pites para a reação do molibdênio a molibdato, o molibdênio pode reagir com íons agressores, como o cloreto, reduzindo assim a velocidade da corrosão por pite.

Os mesmos autores avaliaram o efeito do molibdato, benzotriazol e do ácido hidroxietilideno-1-1-difosfônico como inibidores da corrosão para o aço, cobre, alumínio e estanho. A proposta dos autores foi, visando à substituição do cromo, estudar o uso do mobdato de sódio, ou da mistura dele com outros inibidores, como inibidor da corrosão para o aço-carbono e outros metais em meio simulando a água de refrigeração. O meio foi preparado como no estudo de Farr e Saremi (1982). Para o estudo, os autores obtiveram curvas de polarização com velocidade de varredura de $0,2 \mathrm{mV} \cdot \mathrm{s}^{-1}$ e tempo de imersão de zero e 90 minutos. A caracterização química da superfície do metal foi realizada por espectroscopia de Rutherford (espectrometria por espalhamento de íons de alta-energia) e de Emissão Auger. Através das curvas de polarização do aço em meio simulado de água de refrigeração na ausência de inibidores, os autores observaram que com o aumento do tempo de imersão o potencial de corrosão do aço tornou-se menor e a densidade de corrente maior. No entanto, ao adicionar ao meio $3,1.10^{-3}$ mol. $\mathrm{L}^{-1}$ de $\mathrm{MoO}_{4}{ }^{2-}$ os 
autores observaram uma significante passivação do aço-carbono. Pelas análises de espectroscopia de Rutherford, detectou-se mais de $10 \%$ de molibdênio distribuído pela camada passivada. A espectroscopia de Emissão Auger revelou a existência de pequenos pites na região passivada e nestes pites a concentração de molibdato foi superior a $25 \%$. Os cientistas obtiveram curvas de polarização potenciodinâmicas do aço, do cobre, do estanho e do alumínio no meio proposto com os inibidores estudados. Os resultados obtidos permitiram aos autores concluir que para o molibdato aumentar o potencial de corrosão dos metais estudados é necessário um período de pelo menos 90 minutos de imersão. Assim foi concluído que ocorre uma inibição cooperativa entre 0 molibdato e 0 benzotriazol e com 0 ácido hidroxietilideno-1-1-difosfônico tanto para o alumínio como para o aço (FARR, SAREMI, 1983).

\subsubsection{A aplicação do tungstato de sódio como inibidor de corrosão}

Azabuja, Martini e Müller (2003) estudaram o comportamento corrosivo do ferro e do aço inoxidável (AISI 304) em solução aquosa aerada de cloreto na presença do tungstato de sódio para eletrodo estático e rotativo. Como técnicas para avaliar o comportamento eletroquímico desses metais foram usadas medidas de potencial de corrosão, voltametria cíclica e espectroscopia de impedância eletroquímica. $\mathrm{Na}$ presença do íon tungstato, os valores de $\mathrm{E}_{\text {corr }}$ (potencial de corrosão) dos metais deslocam-se para valores mais positivos. Os autores também observaram que, em solução aerada, os potenciais de corrosão do aço inoxidável e do cromo são similares, sendo um indicativo de que sobre o aço inoxidável ocorra à formação de óxido de Cr (IV). Realizando a medida de potencial de corrosão com tempo de imersão do ferro em solução com 0,05 mol. $\mathrm{L}^{-1}$ de tungstato, os autores observaram que o potencial de corrosão para o eletrodo com rotação de 1000 rpm é mais negativo que para o eletrodo estático e que a evolução do potencial é mais lenta na situação de eletrodo rotativo. Ensaios realizados de voltametria cíclica com o ferro e com o aço inoxidável no meio em estudo demonstraram que a rotação do eletrodo inibiu a corrosão por pite. Também verificou-se altos valores de capacitância para este meio, conduzindo os autores a interpretar que na presença de cloreto, para um tempo de imersão prolongado, o filme passivado formado sobre 
o ferro torna-se defeituoso e poroso. Pelos resultados apresentados os autores concluíram que a ação inibidora do ânion de tungstato esta relacionado com a sua adsorção na superfície do metal e é dependente da presença de oxigênio no meio, comportamento que pode ser atribuído a propriedade oxidativa do ânion tungstato. $A$ inibição da corrosão pelo tungstato independe da hidrodinâmica do sistema, porém esta favorece o transporte do tungstato do meio a superfície aumentando assim a eficiência de inibição da corrosão generalizada e por pite. O filme formado sobre a superfície metálica com o íon tungstato pode ser refeito, e isto aumenta a estabilidade do filme formado. Esta característica pode estar relacionada com a força de adsorção do tungstato à superfície metálica, protegendo-a contra a corrosão, e a sua capacidade de agir como um tampão no meio ácido minimizando assim a acidificação local e a corrosão por pite.

\subsubsection{Sinergismo entre o molibdato de sódio e do tungstato de sódio como inibidores de corrosão}

Alentejano e Aoki (2004) estudaram a eficiência dos oxiânios tungstato e molibdato na inibição da corrosão por pite do inox 304 em água pura desaerada em presença e ausência de 200 ppm de $\mathrm{Cl}^{-}$. Para o estudo, elas realizaram medidas eletroquímicas de monitoramento de potencial de circuito aberto e levantaram curvas de polarização cíclica, a temperatura ambiente e a $90^{\circ} \mathrm{C}$, com o eletrodo estático e rotativo. Utilizou-se molibdato de amônio $\left[\left(\mathrm{NH}_{4}\right)_{6} \mathrm{Mo}_{7} \mathrm{O}_{24}\right]$ e tungstato de sódio $\left(\mathrm{Na}_{2} \mathrm{WO}_{4}\right)$ nas concentrações de $10^{-4} \mathrm{~mol}^{-1} \mathrm{~L}^{-1}$ e $10^{-3} \mathrm{~mol} . \mathrm{L}^{-1}$. Pelos resultados obtidos foi verificado que a adição dos oxiânios aumenta a qualidade do filme passivo sobre o aço inoxidável 307 , mas a $90^{\circ} \mathrm{C}$ todos potenciais observados foram menores que os obtidos a temperatura ambiente. Para o meio na presença e ausência de 200 ppm de $\mathrm{Cl}^{-}$, o aumento do potencial do pite ocorre devido ao aumento da concentração do tungstato e do molibdato. Contudo, o aumento da temperatura reduz o potencial do pite, indicando que a eficiência dos oxiânios é reduzida com o aumento da temperatura. A influência das condições hidrodinâmicas favorece 0 transporte entre o filme e o meio do pite, melhorando a qualidade das curvas de polarização cíclica, ou seja, o acompanhamento da inibição da corrosão do pite. 
Também foi observado que oxiânio molibdato sempre mostrou melhor eficiência que o tungstato.

Abdah e colaboradores (2006) estudaram o molibdato de sódio, o tungstato de sódio e o monovanadato de sódio. Realizaram estudo com a mistura dessas moléculas como inibidores de corrosão. Para tanto, fizeram medidas de potencial de corrosão e curvas de polarização potenciostática. Todo estudo foi desenvolvido para aço-carbono em meio de $\mathrm{NaCl} 3,5 \%$. Foram utilizados também alguns corantes a base de azo compostos. Inicialmente constatou-se que quanto maior era a concentração de $\mathrm{NaCl}$ em solução, na qual o aço esteja imerso, mais negativo era o seu potencial de corrosão e maior era a velocidade de corrosão. Porém, quando adicionada uma determinada quantidade dos inibidores em solução os potencias de corrosão aumentavam e as velocidades de corrosão diminuíram. Atribuiu-se este comportamento da inibição da corrosão à formação de um filme sobre a superfície do metal formada por sais e complexos insolúveis. Verificou-se também que o molibdato de sódio é mais eficiente entre os sais estudados, segundo eles o melhor desempenho do molibdato é devido à redução do $\mathrm{Mo}^{4+}\left(\mathrm{MoO}_{4}{ }^{2-}\right)$ a $\mathrm{Mo}^{+2}\left(\mathrm{MoO}_{2}\right)$ durante a formação do filme, fazendo com que o oxigênio gerado da reação interfira na penetração do $\mathrm{Cl}^{-}$na interface metal/filme.

Robertson (1951) realizou um estudo comparativo da inibição da corrosão do ferro pelos íons de molibdato, tungstato, cromato e nitrito para avaliar a eficiência relativa dos quatro diferentes íons e seus mecanismos de inibição. Para este estudo, o autor realizou ensaios de perda de massa em meio de água destilada continuamente aerado com e sem os inibidores. O tempo de imersão para os ensaios foi de sete dias e o pH da solução foi mantido entre 6,5 e 7,5. A superfície dos corpos-de-prova foi ativada com ácido sulfúrico $2 \mathrm{~mol} . \mathrm{L}^{-1}$ a temperatura de $80^{\circ} \mathrm{C}$ por 20 minutos. Também foram realizados ensaios de medida de potencial de corrosão para o meio com o pH crescente, de ácido a básico, para verificar o mecanismo de inibição do molibdato. Os resultados dos experimentos mostraram que os quatro íons agem como inibidores da corrosão do ferro no meio proposto e a eficiência de inibição deles são próximas. Para todos os inibidores cessarem completamente a corrosão, a concentração necessária para cada um era relativamente baixa. Para o meio com concentração baixa de molibdato de sódio o 
autor verificou que ocorrem regiões chamadas por ele de "ativo-passiva", isto porque o molibdato reage com o hidróxido férrico, produto da corrosão, e se a concentração de molibdato no meio for baixa, acaba por existir descontinuidades da adsorção do molibdato na superfície do metal provocando uma corrosão localizada. Através dos ensaios de polarização verificou-se que o molibdato e o tungstato não são inibidores oxidantes em meio neutro e ácido. Eles também consideraram o cromato como agente muito oxidante e o nitrato pouco oxidante. Com os resultados os autores puderam supor que o molibdato e o tungstato são inibidores de corrosão eficientes, comparável com o cromato e o nitrato, e que existe uma quantidade mínima necessária para que ambos iniciem o processo de inibição.

O efeito da inibição da corrosão do aço pelo molibdato e tungstato em meio de ácido clorídrico $\left(0,1\right.$ mol.L ${ }^{-1}$ a 0,5 mol. $\left.\mathrm{L}^{-1}\right)$ foi investigado por meio de medidas de perda de massa e métodos eletroquímicos por Guannan e colaboradores (2006). Os resultados revelaram que tanto 0 molibdato quanto 0 tungstato agem como eficientes inibidores de corrosão em baixas concentrações. No entanto, em baixas concentrações, a eficiência de inibição do tungstato é melhor do que a do molibdato. $A$ adsorção dos inibidores na superfície do aço obedece à equação da isoterma de adsorção de Langmuir. $O$ efeito da temperatura no comportamento corrosivo do aço foi estudado a temperatura de $25^{\circ} \mathrm{C}$ e $35^{\circ} \mathrm{C}$, calculando-se também a entalpia e a energia livre de adsorção. Sob as mesmas condições, a comparação da eficiência de inibição entre o molibdato e o tungstato revelou que o molibdato apresenta maior inibição em meio de 0,1 mol. $\mathrm{L}^{-1}$ de $\mathrm{HCl}$, logo a eficiência é dependente da concentração de $\mathrm{HCl}$. Pelos resultados os autores puderam supor que o molibdato não tem uma forte eficiência de inibição comparada com a do tungstato para baixas concentrações, mas o molibdato é o melhor inibidor para uma larga faixa de concentrações. $O$ estudo cinético da reação de oxidação do aço em meio ácido sem e com inibidores foi também discutido. Outro ponto importante observado pelos autores é que as curvas de polarização mostraram que o molibdato e o tungstato são inibidores do tipo misto para o aço em meio ácido. Neste estudo, os autores observaram que em meio ácido o molibdato $\left(\mathrm{MoO}_{4}{ }^{2-}\right)$ e o tungstato $\left(\mathrm{WO}_{4}{ }^{2-}\right)$ reagem e transformam-se em vários polimolibdatos e politungstatos, respectivamente. Em baixas concentrações dos inibidores, em meio ácido, o tungstato é mais facilmente 
adsorvido na superfície do aço. Este comportamento pode ser explicado, pois as espécies formadas pela reação do $\mathrm{WO}_{4}{ }^{2-}$ com $\mathrm{O} \mathrm{H}^{+}-$politungstatos $\left(\left[\mathrm{H}_{2} \mathrm{~W}_{12} \mathrm{O}_{40}\right]^{6-}\right.$, $\left[\mathrm{W}_{6} \mathrm{O}_{19}\right]^{2-},\left[\mathrm{W}_{12} \mathrm{O}_{42} \mathrm{H}_{2}\right]^{10-}$ e $\left.\mathrm{HW}_{6} \mathrm{O}_{21}{ }^{5-}\right)$ - são facilmente adsorvidas sobre o ferro, além do $\mathrm{WO}_{4}{ }^{2-}$ reagir com o ferro formando sobre a sua superfície o $\mathrm{FeWO}_{4}$. Em contrapartida, os produtos da reação do $\mathrm{MoO}_{4}{ }^{2-}$ com $0 \mathrm{H}^{+}-$polimolibdatatos $\left(\mathrm{Mo}_{7} \mathrm{O}_{24}{ }^{6-}\right.$ e $\left.\mathrm{Mo}_{8} \mathrm{O}_{26}{ }^{4-}\right)$ - não são facilmente adsorvidos na superfície do aço. Porém, quando a concentração do molibdato é alta, o produto da reação do $\mathrm{MoO}_{4}{ }^{2-}$ com o ferro é fortemente aderente a superfície metálica. $\mathrm{O} \mathrm{MoO}_{4}{ }^{2-}$ também reage com o $\mathrm{Cl}^{-}$ e o $\mathrm{OH}^{-}$, gerando íons que formam complexos altamente resistentes a corrosão, que quando adsorvidos na superfície metálica inibem à corrosão da peça metálica. Os autores verificaram que a constante cinética $(k)$ do molibdato é menor que a do tungstato para a mesma concentração do inibidor na solução, $200 \mathrm{~g} \cdot \mathrm{L}^{-1}$. Este estudo concluiu que à inibição da corrosão para o aço-carbono em meio ácido pelo molibdato é superior à inibição do tungstato.

\subsubsection{Aplicação dos silanos e tensoativos como inibidores de corrosão}

Os silanos, ou organofuncional silanos (organosilanos), são conhecidos por fornecer boa proteção contra a corrosão, além de serem muito utilizados como promotores de adesão para revestimento orgânico. Estes compostos vêm sendo utilizados em substituição aos processos de cromatização e de fosfatização (REIS, 2005), além de estar sendo avaliado como método de proteção contra a corrosão por alguns grupos de pesquisa, dentre eles o grupo de Aoki (SOUZA, 2005). Recentes publicações já comprovaram a eficiência do uso de silano em inibir a corrosão do alumínio e suas ligas, das ligas ferrosas, do cobre, do zinco, além das ligas de magnésio. Os estudos direcionados para a proteção de metais utilizando silanos vêm procurando melhorar a sua eficiência através da identificação de novos compostos a base de silanos, identificação de solventes, concentração de silano, pH da aplicação, método de recobrimento, tempo de hidrólise, tipos e tempo de cura (SUBRAMANIAN; VAN OOIJ, 1998, 1999; SCHAFTINGHEN et. al., 2004). 
Os organosilanos são também classificados como tensoativos a base de silano. Quando os tensoativos são adicionados ao meio líquido reduzem a tensão superficial aumentando a capacidade de espalhamento ou de umectação da solução, propiciando a superfície do material exposto ao meio a ficar encerrada em uma película elástica, desta forma, quanto maior a concentração de organosilanos em solução, melhor será a proteção contra a corrosão do metal exposto ao meio (MYERS, 1992 apud DEMARQUE et al., 2005).

Quando a concentração das moléculas dos tensoativos se aproxima à da concentração de micela crítica $(\mathrm{cmc})$, são típicas as medidas de $\mathrm{cmc}$ no contexto do uso de tensoativos a base de silano como inibidores de corrosão. Abaixo da $\mathrm{cmc}$, as moléculas de surfactantes tendem a adsorverem na superfície de contato, logo a agregação interfacial reduz a tensão superficial e está relacionada com a inibição da corrosão. Acima da cmc, a tensão superficial não mais se altera, tendo em vista que o excesso de tensoativo forma micelas na solução, logo, não altera o filme já formado na superfície do metal e, por conseguinte não altera a densidade de corrente de corrosão (FREE, 2002; WANG, FREE, 2004).

WanLin e Free (2004) utilizaram os tensoativos aniônicos dodecanol, decanol e octanos, como inibidores de corrosão para o aço doce em solução de $\mathrm{NaCl}$ $0,5 \mathrm{~mol}^{-\mathrm{L}^{-1}}$. Para a análise das propriedades de inibição da corrosão os autores utilizaram medidas de tensão superficial e da densidade de corrente de corrosão. Nos ensaios de tensão superficial, os autores observaram que o aumento da concentração dos surfactantes diminui a tensão superficial da solução $(\gamma)$, no entanto a tensão superficial é mínima é em torno da cmc. Os autores também verificaram que a densidade de corrente de corrosão diminui com o aumento da concentração dos surfactantes em solução, tendo a eficiência máxima como inibidores da corrosão do aço doce em solução de $\mathrm{NaCl} 0,5 \mathrm{~mol} . \mathrm{L}^{-1}$ em concentrações próximas a cmc.

Shalab e colaboradores (1999) estudaram a inibição da corrosão do açocarbono pelo aniônico polioxi etileno palmitat $\left(\mathrm{Pa}(\mathrm{EO})_{80}\right)$, catiônico hexadeciltrimetilamônio bromato (HTABr) e aniônico sódio dodecil sulfato (SDS) em 
água do mar naturalmente aerada. Foram feitas medidas de perda de massa e análise por raios $X$ dos filmes formados. Os corpos-de-prova foram inicialmente polidos e desengraxados. As medidas de perda de massa foram realizadas após sete dias de imersão. A eficiência de inibição destes componentes aumentou com a concentração e o valor máximo foi em torno da contração miscelar crítica (cmc). A isoterma de adsorção testada foi a de Langmuir e a adsorção máxima calculada a partir da equação da isoterma de Langmuir foi crescente na ordem de SDS $<\mathrm{HTABr}<$ $\mathrm{Pa}(\mathrm{EO})_{80}$. O espectro de raios $\mathrm{X}$ mostrou que a adsorção destes componentes na superfície do aço é através do $\mathrm{FeOOH}$.

Souza e colaboradores (2005) investigaram a aplicação do copolímero de polioxialquileno e polidimetilsiloxano modificado (CPPM), um organosilano, como inibidor da corrosão para o aço ABNT 1005 em meio de $\mathrm{HCl} 2$ mol. $\mathrm{L}^{-1}$. Para tal objetivo, os autores utilizaram a técnica de ensaio de imersão com medida de perda de massa, medida de potencial de corrosão, curvas de polarização potenciodinâmica anôdica e catódica e espectroscopia de impedância eletroquímica. A caracterização da superfície foi realizada por microscopia eletrônica de varredura (MEV). Os resultados mostraram que a eficiência do CPPM como inibidor de corrosão do aço ABNT 1005 em meio de $\mathrm{HCl} 2$ mol.L ${ }^{-1}$ é superior a 95\%. Os autores também constataram que a molécula deste organosilano age com como um inibidor misto.

Demarque e colaboradores (2005) utilizaram um copolímero de polioxialquileno e polidimetilsiloxano modificado com peso molecular igual a 5.000 g.mol ${ }^{-1}$ como inibidor da corrosão do aço-carbono ABNT 1005 em meio de 5\% de $\mathrm{HCl}$ naturalmente aerado. Os ensaios de medida de perda de massa foram realizados em meio de $\mathrm{HCl}$ sem e com o copolímero. Os resultados obtidos apresentaram uma eficiência máxima de $89 \%$ e uma tensão superficial igual a 37,2 $\mathrm{mN} . \mathrm{m}^{-1}$ para uma concentração de $4,0 \times 10^{-4} \mathrm{~mol} \cdot \mathrm{L}^{-1}$. A adsorção do copolímero sobre a superfície metálica obedece a isoterma de adsorção de Langmuir, sendo que o mecanismo de adsorção é por quimissorção. As medidas de polarização mostraram que o copolímero estudado atuou como inibidor do tipo misto. Dos resultados de impedância os autores concluíram que os valores de resistência a transferência de carga, $R_{\text {tc }}$, são crescentes com o aumento da concentração do copolímero de 
polixialquileno e polidimetilsiloxano em solução. Eles também verificaram a formação de dois arcos capacitivos, um a alta freqüência, que pode estar relacionado com a formação de um filme na superfície do aço, e outro em baixa freqüência, que deve estar relacionado aos processos de transferência de carga na interface metal/eletrólito. Pelos diagramas de Bode foi observado que a impedância do sistema aumentou para concentrações crescentes de inibidor, assim como o ângulo de fase.

\subsubsection{Inibidores multicomponentes}

Em geral, na prática o uso de inibidores de corrosão é através da adição de dois ou mais inibidores. Estes inibidores agem através da ação de sinergismo entre eles, ou seja, o aumento da eficiência de inibição da corrosão do metal em um determinado meio corrosivo ocorre através da ação combinada de duas ou mais substâncias (JEYAPRABHA et al., 1988; UHLING, 1966).

Jeyaprabha e colaboradores (1998) estudaram o efeito de uma mistura de amina, ester e amônio quartenário como inibidores de corrosão para equipamentos de campo de petróleo. Eles observaram a inibição da corrosão do aço N-80 em meio de $15 \%$ de ácido clorídrico a $303 \mathrm{~K}$ por diferentes formulações de inibidores. Para o estudo eles utilizaram medidas de perda de massa expondo as peças por 5 horas no meio proposto. As técnicas usadas neste estudo foram de polarização potenciodinâmica catódica e anódica e medidas de espectroscopia de impedância eletroquímica. Com os resultados obtidos, os pesquisadores puderam identificar que a formulação contendo 3000 ppm de amina, 1000 ppm de éster e 1000 ppm de amônio quartenário é ideal para inibir cerca de $73 \%$ da corrosão do aço $\mathrm{N}-80$ no meio estudado.

Malik (2001) investigou o efeito das cargas dos inibidores de corrosão com a variação do $\mathrm{pH}$. Foram utilizadas neste estudo aminas quartenárias e terciárias como inibidores da corrosão do aço-carbono, sendo as técnicas usadas de 
monitoramento da potencial de corrosão, medidas de resistência a polarização e curvas de polarização catódicas. Os resultados mostraram-lhe que o desempenho do tipo de inibidor depende do $\mathrm{pH}$ da solução. Com o pH 6,5, a eficiência máxima é obtida com a adsorção de inibidores com $\mathrm{O}^{-}$, sugerindo que a superfície do metal nesta condição esteja carregada de cargas positivas. Contudo, com o pH 3,9 da solução a adsorção de inibidores com átomos positivos é favorecida, assim a eficiência de inibidores com átomos de $\mathrm{N}^{+}$é maior.

Ochoa e colaboradores (2002) estudaram uma mistura de ácido carboxílico associado a um sal de ácido fosfônico (PCAS), um biocida a baixa dosagem e sais quartenários de amônio como inibidores de corrosão do aço-carbono utilizado em circuitos de refrigeração da água. Para avaliar as propriedades inibidoras da mistura eles realizaram ensaios de potencial de corrosão com 2 horas de imersão, curvas de polarização potenciodinâmica e impedância eletroquímica. Para estes ensaios eles utilizaram como eletrodo de referência um eletrodo de calomelano saturado (SCE) e como contra-eletrodo uma grade de platina, os ensaios ocorreram com $200 \mathrm{mg} \cdot \mathrm{L}^{-1} \mathrm{a}$ $\mathrm{pH}$ 10, ao eletrodo de trabalho foi aplicado rotação de $100 \mathrm{rpm}$. Eles ainda caracterizaram a superfície do aço por espectroscopia fotoelétrica de raios X (XPS) antes e depois de imerso no meio com a mistura de inibidores. Os resultados dos ensaios eletroquímicos mostraram que o PCAS age como um inibidor anódico, apesar de não alterar o potencial de corrosão e não ser capaz de inibir a corrosão localizada mesmo aumentando a sua concentração em solução, porém com 200 $\mathrm{mg} \cdot \mathrm{L}^{-1}$ de PCAS e mais $50 \mathrm{mg} \cdot \mathrm{L}^{-1}$ de biocida eles encontraram o ponto ideal entre a melhor eficiência com o menor custo. A seguir, adicionaram $12,5 \mathrm{mg} \cdot \mathrm{L}^{-1}$ de um sal quaternário, o que permitiu reduzir a corrosão localizada. Pelos resultados das análises da superfície do metal, os pesquisadores puderam ver que, mesmo antes da imersão, a superfície do metal já estava recoberta por óxidos e hidróxidos de ferro, e após a imersão este óxidos e hidróxidos de ferro continuavam presentes no filme. A análise da subcamada do óxido do metal após a imersão apresentou aos pesquisadores que o PCAS, o biocida e o sal quaternário de amônio estavam presentes na composição do óxido, podendo eles concluir que a mistura adere à superfície do metal. 


\subsection{Espectroscopia de Impedância Eletroquímica (EIE)}

As medidas EIE vêm sendo utilizadas como um instrumento eficaz para estudo e compreensão da corrosão dos metais, constituindo-se em uma das ferramentas mais empregadas pelos pesquisadores para a investigação do comportamento de interfaces eletroquímicas.

O método baseia-se na aplicação de perturbações, em potencial ou em corrente com variação senoidal, de pequena amplitude e com freqüências variadas, sobre um eletrodo em estado estacionário. A relação temporal entre o potencial e a corrente corresponde à impedância do sistema. Quando a resposta for dada em corrente e estiver defasada em relação ao potencial aplicado, o sistema tem características capacitivas ou indutivas e a impedância tem um componente imaginário. Quando não houver defasagem, a impedância tem apenas um componente real, e o comportamento é resistivo. Estes diferentes comportamentos e a sua variação ao longo de uma varredura de freqüência podem ser associados a características do processo eletroquímico (MELO, 2003; WOLYNEC, 2003).

Sabe-se que, em um circuito de corrente alternada (AC), o potencial elétrico $E(t)$ varia com o tempo $t$, logo a relação entre este potencial e a corrente elétrica $i(t)$ é a impedância (Z), conforme a relação apresentada na eq. (1), onde $f$ é a freqüência com que a corrente alternada oscila, normalmente medida em Hertz $(\mathrm{Hz})$. O $w(w=2 \pi f)$ é expresso em radianos. Sendo $\theta$ o ângulo de fase, ou seja, a defasagem entre $V$ (potencial) e $I$ (corrente), determinada pelos processos de relaxação.

$$
Z=\frac{E(t)}{I(t)}=\frac{V_{O} \cos (w t)}{I_{O} \cos (w t-\theta)}
$$

Como a impedância $(Z)$ pode ser expressa por um componente real $(Z)$ e por um componente imaginário $\left(Z^{\prime}\right)$, é possível exprimir a impedância por meio da relação apresentada na eq. (2):

$$
Z=Z^{\prime}+j Z^{\prime \prime}(2)
$$

onde $j$ é o número complexo, isto é, $j^{2}=-1$. 
O módulo da impedância por sua vez é dado pela eq (3):

$$
|Z|=\left(Z^{\prime 2}+Z^{\prime 2}\right)^{\frac{1}{2}}
$$

sendo: $Z^{\prime}=|Z| \cos \theta, Z^{\prime \prime}=|Z| \operatorname{sen} \theta$ e $\theta=\operatorname{arctg} \frac{Z^{\prime \prime}}{Z^{\prime}}$.

A impedância é geralmente representada através dos diagramas de Nyquist e de Bode. O diagrama de Nyquist é representado por um gráfico do componente imaginário, $Z^{\prime \prime}$, versus o componente real, $Z^{\prime}$, para diferentes freqüências. $O$ diagrama de Bode é representado por dois gráficos, sendo um log $|Z|$ versus $\log f$ e o outro $\theta$ versus $\log f$.

Um sistema eletroquímico simples é o de um metal imerso num eletrólito e o circuito elétrico que melhor representa este sistema é o da Figura 2.8.

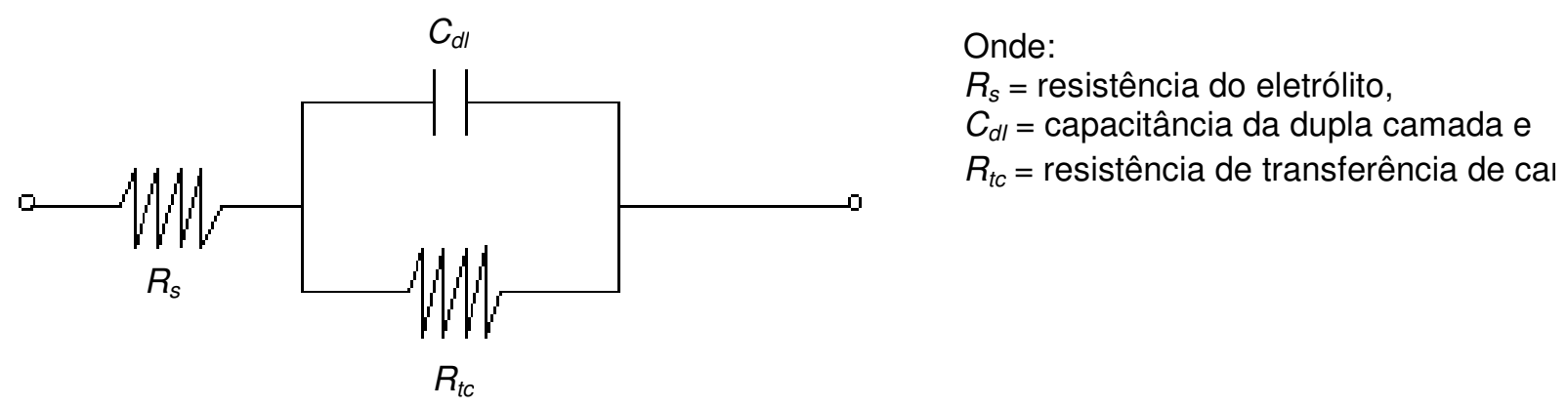

Figura 2.8 - Circuito elétrico equivalente do sistema metal/eletrólito

Este sistema produz diagramas de Impedância conforme mostra a Figura 2.9:

Diagrama de Nyquist

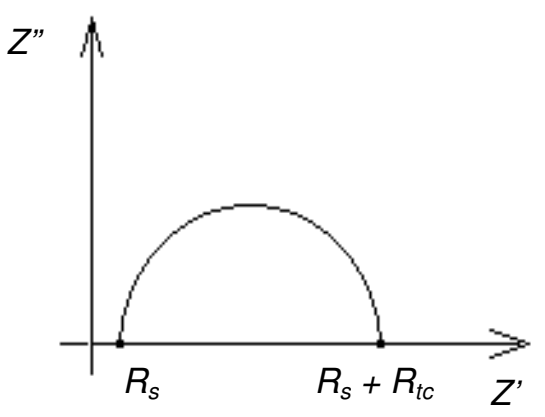

Diagrama de Bode

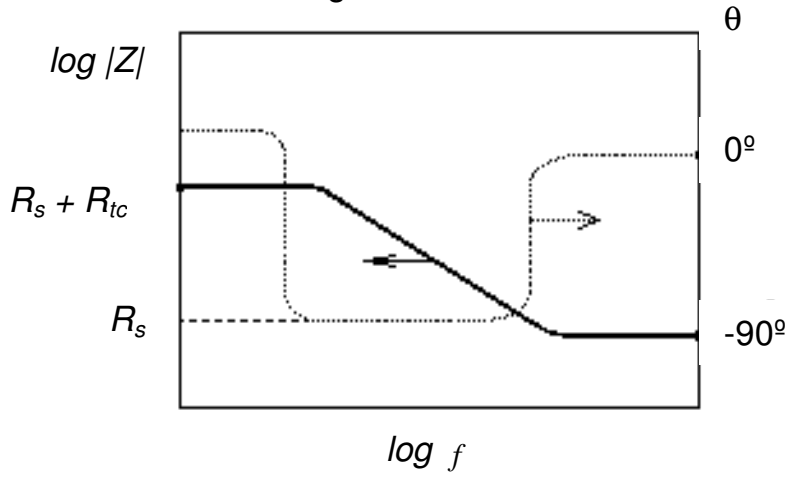

Figura 2.9 - Diagramas de Nyquist e Bode para o sistema metal/eletrólito 
Uma das vantagens deste sistema é que a perturbação pode ser de pequena amplitude permitindo admitir que o sistema esteja trabalhando em uma região linear, evitando assim funções matemáticas complexas, como é característico das interfaces eletroquímicas. Também, com este sistema, é possível impor a perturbação em uma ampla gama de freqüências e obter informações sobre os diversos processos eletroquímicos que ocorrem na interface do eletrodo com a solução, sendo esses processos caracterizados por constantes de tempo. Através destas constantes é possível tirar informações concernentes aos processos eletroquímicos que ocorrem na interface. Também é possível trabalhar sob condições de polarização permitindo identificar eventuais mudanças no mecanismo de reação da interface em virtude da polarização introduzida.

Existem duas vertentes na literatura quanto à metodologia de se interpretar os resultados dos experimentos de EIE.

A primeira refere-se à interpretação que permite obter através dos diagramas (Fig. 2.9) uma análise qualitativa do sistema (WOLYNEC, 2003).

A segunda vertente baseia-se na simulação e interpretação dos resultados através dos circuitos elétricos equivalentes, cujo objetivo é quantificar os parâmetros eletroquímicos. Dentre os estudos publicados sobre as interpretações da resposta da interface utilizando circuitos elétricos equivalente, destaca-se o trabalho de Mansfeld e colaboradores (apud Bonora et al, 1996). Eles propuseram dois diferentes modelos de circuito elétrico equivalente, o primeiro composto pela capacitância da dupla camada elétrica $\left(C_{d \prime l}\right)$ em paralelo com a resistência a transferência de carga $\left(R_{t c}\right)$, o qual descreve a reação eletroquímica sobre ativação controlada, semelhante ao apresentado na Fig. 2.8, e o segundo circuito proposto por Mansfeld e colaboradores consiste no elemento de Warburg, sendo neste caso para processos difusivos.

O uso do primeiro circuito é comum, pois é simples e satisfatório para vários sistemas, incluindo aqueles com macro defeitos no filme. Bonora e colaboradores (1996) realizaram uma simulação e interpretação dos resultados de EIE através dos circuitos elétricos equivalentes para revestimentos orgânicos e destacaram que para usar circuitos elétricos equivalentes duas condições devem ser respeitadas:

$\left.1^{\mathrm{a}}\right)$ todos os elementos do circuito proposto devem ter significado físico claro; 
$2^{a}$ ) o circuito elétrico equivalente deve ser o mais simples possível, e o erro é aceitável se este não for apenas pequeno, mas também não-periódico.

Se a $1^{a}$ condição não for satisfeita, este modelo não corresponde ao significado físico; se a $2^{\mathfrak{a}}$ condição não for satisfeita, este modelo não é consistente com o resultado experimental.

Para o estudo os autores recobriram uma peça de aço-carbono com resina epóxi, poliéster e fluoropolímero e fizeram medidas de espectroscopia de impedância eletroquímica. Os diagramas do metal recoberto por fluoropolímero apresentam duas constantes de tempo. O circuito elétrico equivalente proposto foi o composto por capacitância do filme $\left(C_{\text {filme }}\right)$, resistência do filme $\left(R_{\text {filme }}\right)$, capacitância da dupla camada elétrica $\left(C_{d l)}\right.$ e resistência à transferência de carga $\left(R_{t c}\right)$. As capacitâncias foram calculadas matematicamente com auxílio da constante de fase $(C P E)$, pois, neste caso, foi considerado que o comportamento eletroquímico do sistema não corresponde exatamente à capacitância pura; podendo ser discutido em termos dos fenômenos de difusão, morfologia da superfície e processos de dissipação. Assim, para representar a capacitância são utilizados a admitância $Q$ (com dimensão $\left.\Omega \cdot \mathrm{cm}^{2} \cdot \mathrm{s}^{-(1-\alpha)}\right)$ e o da freqüência angular $\omega(\omega=2 \pi f)$, sendo $f$ a freqüência e $\alpha$ está relacionado com a rotação angular da linha de capacitância pura no plano complexo, de acordo com a eq.(4).

$$
Z_{C P E}=\frac{Q}{(j w)^{1-\alpha}}
$$

$\mathrm{Na}$ eq. (4) $j$ é um número imaginário $(j=\sqrt{-1})$ e quando $\alpha=1$ o CPE representa um capacitor, quando $\alpha=-1$ um indutor (Brug apud Jorcin, 2006).

A técnica de impedância eletroquímica também é utilizada para avaliar o comportamento de inibidores de corrosão. Um sistema desse tipo pode ser representado por um circuito equivalente conforme mostrado na Figura 2.8 e os diagramas de Nyquist característicos podem também ter comportamento semelhante ao apresento na Figura 2.10.

$\mathrm{Na}$ Figura 2.10a o diagrama representado é típico de um sistema onde as características capacitivas dominam a característica resistiva do sistema. Esta reta na 
realidade não é uma reta e sim o início de um imenso arco que fecharia em freqüências extremamente baixas (Fig. $2.10 \mathrm{~b}$ e 2.10c). À medida que o sistema passa a ter características resistivas, esse arco intersecciona o eixo real no valor $R_{s}+R_{t c}$ o que significa que ele vai perdendo sua capacidade como sistema protetor (Fig. 2.10c).

a)

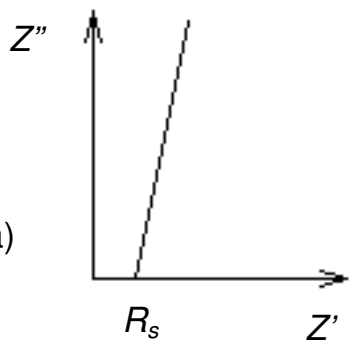

b)

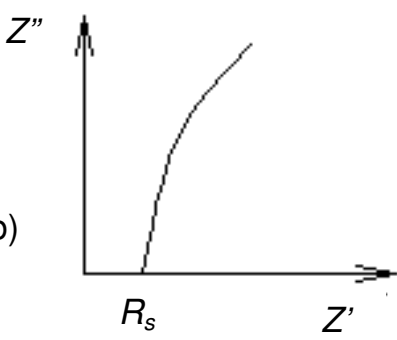

c)

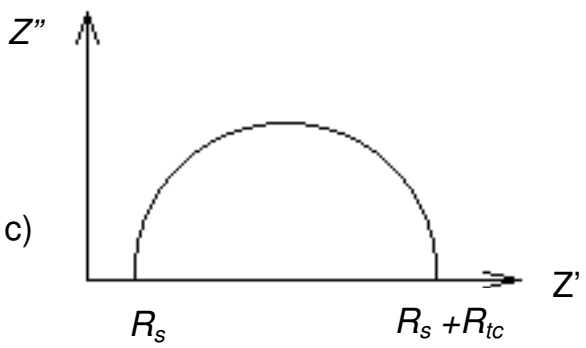

Figura 2.10 - Diagramas de Nyquist para sistema com características capacitivas (a e b) e características resistivas (c).

A Figura 2.11 apresenta diagramas de Nyquist característicos para estudo de inibidores de corrosão. Neste diagrama observa-se que à medida que se aumenta a concentração do inibidor o diâmetro do arco capacitivo aumenta e, portanto a intersecção do arco com o eixo real ( $\left.Z^{\prime}\right)$ torna-se maior, indicando uma maior resistência a transferência de carga $\left(R_{t c}\right)$ na interface metal/solução (VILLARROEL, 2007).

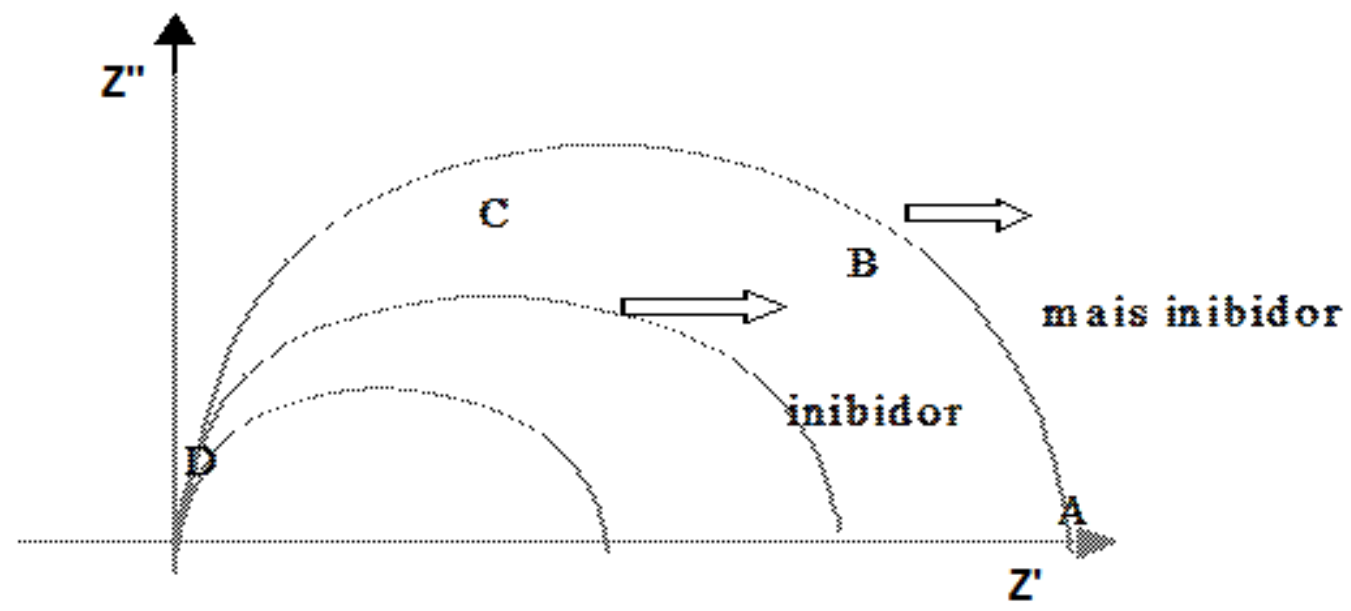

Figura 2.11 - Efeito do inibidor sobre os diagramas de Nyquist. 


\section{MATERIAIS E MÉTODOS}

\subsection{Materiais}

O material utilizado para este estudo foi o aço-carbono ABNT 1005. Sua análise química foi realizada no laboratório da Companhia Siderúrgica Paulista. A Tabela 3.1 apresenta a composição química do aço estudado.

Tabela 3.1 - Composição química do aço-carbono ABNT 1005 utilizado neste estudo

\begin{tabular}{cccccccc}
\hline $\mathbf{C} \%$ & $\mathbf{M n} \%$ & $\mathbf{A l} \%$ & $\mathbf{P} \%$ & $\mathbf{S} \%$ & $\mathbf{C r} \%$ & $\mathbf{N i} \%$ & $\mathbf{F e} \%$ \\
\hline 0,050 & 0,300 & 0,050 & 0,016 & 0,011 & 0,010 & 0,002 & $\mathrm{Bal}$ \\
\hline
\end{tabular}

As substâncias utilizadas como inibidores de corrosão foram o molibdato de sódio $\left(\mathrm{Na}_{2} \mathrm{MoO}_{4} \cdot 2 \mathrm{H}_{2} \mathrm{O}\right)$ com peso molecular de $241,95 \mathrm{~g} \cdot \mathrm{mol}^{-1} \mathrm{e}$ o tungstato de sódio $\left(\mathrm{Na}_{2} \mathrm{WO}_{4} \cdot 2 \mathrm{H}_{2} \mathrm{O}\right)$, com peso molecular de $329,86 \mathrm{~g} \cdot \mathrm{mol}^{-1}$, ambos reagentes P.A. da marca Nuclear. Também foi usado um copolímero a base de silano "polioxialquileno e polidimetilsiloxano modificado" (CPPM) que é um surfactante de nome comercial Silwet L-7220 com peso molecular de $17.000 \mathrm{~g} \cdot \mathrm{mol}^{-1}$.

Para este estudo foram utilizados os eletrólitos: água do mar e cloreto de sódio $(\mathrm{NaCl}) 3,5 \%$. A água do mar foi coletada próxima a praia na cidade de Itanhaem, cidade litorânea do estado de São Paulo, e utilizada sem prévio tratamento. A solução de $\mathrm{NaCl} 3,5 \%$ foi preparada com água Mili-Q (Milipore) e o $\mathrm{NaCl}$ usado foi o da marca Synth, P. A. - ACS. 


\subsection{Metodologia}

\subsubsection{Preparação dos corpos-de-prova (tratamento superficial)}

Para os ensaios de perda de massa foram preparados corpos-de-prova retangulares com dimensões aproximadas de $20 \mathrm{~mm}$ de comprimento, $15 \mathrm{~mm}$ de largura por 2,5 $\mathrm{mm}$ de espessura e para os ensaios eletroquímicos foram preparados corpos-de-prova em forma de disco com área exposta de aproximadamente $1 \mathrm{~cm}^{2}$. Todos os corpos-de-prova foram tratados superficialmente com lixas de carbeto de silício com granas 320, 400, 600 e 1200. Em seguida, foram lavados com água deionizada, desengraxados com álcool e acetona e secos em corrente de ar quente.

\subsubsection{Técnicas empregadas neste estudo}

- Ensaios de imersão com medida de perda de massa;

- Medidas de potencial de corrosão $\left(E_{\text {corr }}\right)$;

- Espectroscopia de impedância eletroquímica (EIE);

- Curvas de polarização anódicas e catódicas $\left(\mathrm{C}_{\mathrm{pol}}\right)$.

\subsubsection{Ensaios de imersão com medida de perda de massa}

Os ensaios de imersão com medida de perda de massa foram realizados em meio de água do mar e em meio de $\mathrm{NaCl} 3,5 \%$, todos na ausência das substâncias estudadas como inibidores de corrosão. Os ensaios foram realizados em triplicata e o tempo de imersão foi de 100 horas, 800 horas e 2300 horas e a temperatura ambiente. As peças foram imersas no meio de forma estática a um volume de $80 \mathrm{ml}$. O meio não foi agitado e não foi substituído ao longo do tempo. Ao final do tempo de imersão as amostras foram decapadas para a retirada do produto de corrosão, e a seguir lavadas com água e desengraxadas com álcool, acetona e secas em corrente 
de ar quente. Finalmente foram pesadas e determinadas as velocidades de corrosão.

A solução decapante foi preparada com $20 \mathrm{~g}$ de $\mathrm{Sb}_{2} \mathrm{O}_{3}$ e $50 \mathrm{~g}$ de $\mathrm{SnCl}_{2}$ por litro de $\mathrm{HCl}$ (densidade de 1,19 g. $\mathrm{ml}^{-1}$ ). As amostras foram imersas por 2 minutos na solução decapante e em seguida lavadas como descrito anteriormente.

\subsubsection{Ensaios eletroquímicos}

Para os ensaios eletroquímicos o eletrodo de trabalho foi montado em um porta-eletrodo constituído de polivinilidenodifluorado com contato elétrico interno de aço inoxidável e imerso no meio corrosivo (posicionado na parte central da célula eletroquímica). O eletrodo de referência usado foi de $\mathrm{Ag} / \mathrm{AgCl}_{\mathrm{KCl} \text { lat }}$ (prata/cloreto de prata em solução de cloreto de potássio saturada) e este foi posicionado a frente da amostra com uma distância aproximada de $5 \mathrm{~mm}$. Como contra eletrodo utilizou-se uma placa de platina com área aproximada de $15 \mathrm{~cm}^{2}$. Durante os ensaios a célula eletroquímica foi colocada dentro de uma Gaiola de Faraday, com o objetivo de minimizar possíveis perturbações de sinais externos. A seguir é apresentado um esquema da montagem do sistema utilizado (Figura 3.1).

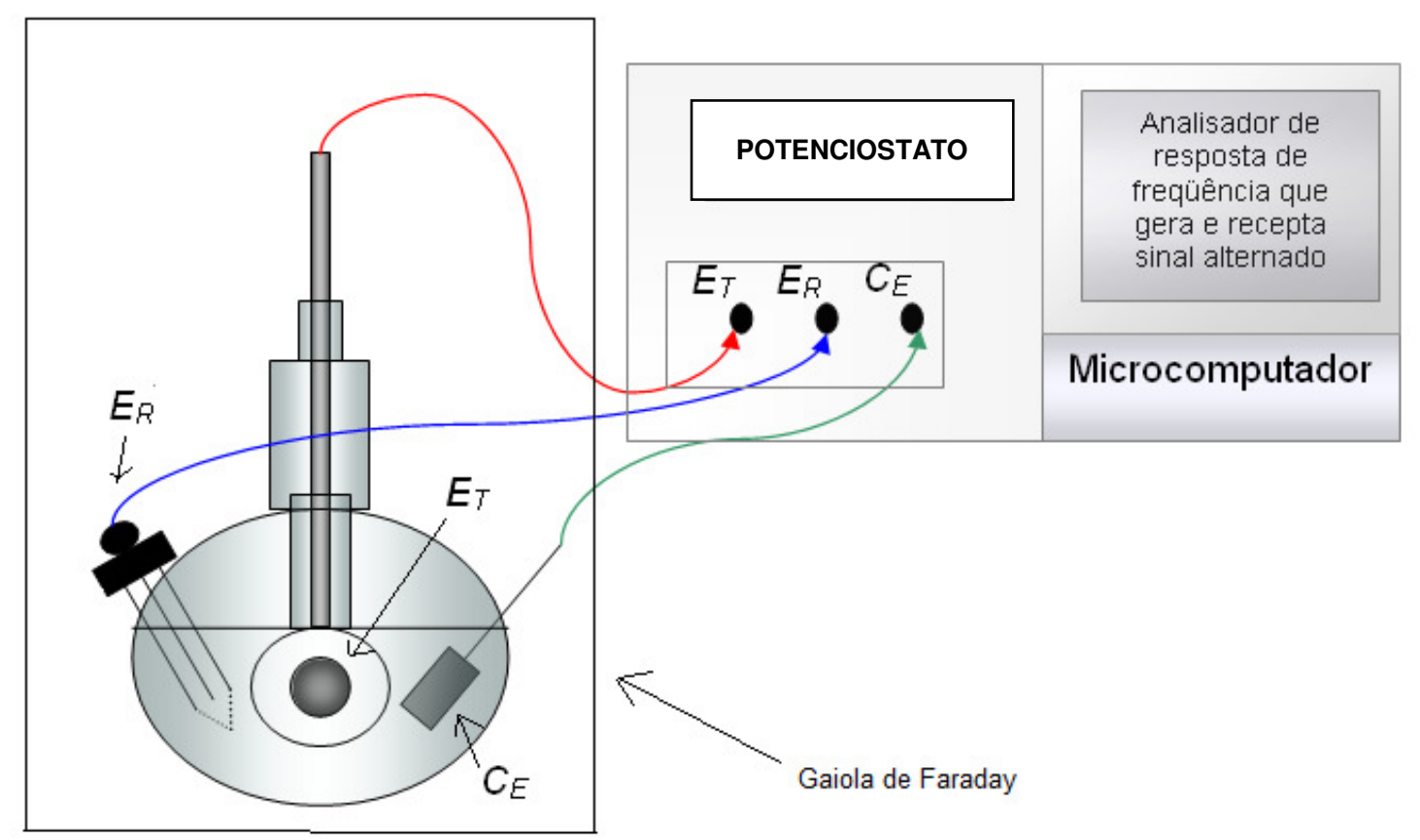

Figura 3.1 - Arranjo esquemático para as medidas eletroquímicas, sendo que: $E T$ - eletrodo de trabalho; $E R$ - eletrodo de referência; $C E$ - contra eletrodo. 
a) Medidas de potencial de corrosão ( $\left.E_{\text {corr }}\right)$

Para as medidas de $E_{\text {corr, }}$ os corpos de prova foram imersos no meio corrosivo, 3,5\% de $\mathrm{NaCl}$, na presença e ausência das substâncias estudadas como inibidores de corrosão, onde o sistema evoluiu espontaneamente até atingir o potencial estacionário. O monitoramente do potencial de corrosão foi feito por 3 horas, 6 horas, 12 horas e 24 horas de imersão.

\section{b) Espectroscopia de impedância eletroquímica (EIE)}

Os espectros de impedância eletroquímica (EIE) foram obtidos para os diferentes tempos de imersão que foram: 3 horas, 6 horas, 12 horas e 24 horas de imersão. A faixa de freqüência estudada foi de $16 \mathrm{kHz}$ a $100 \mathrm{mHz}$. Foram feitas dez leituras por década de freqüência e foi aplicada uma perturbação de $10 \mathrm{mV}$ em torno do $E_{\text {corr. }}$ Os valores de resistência a transferência de carga $\left(R_{t c}\right)$, resistência da solução $\left(R_{s}\right)$ e capacitância da dupla camada elétrica $\left(C_{\text {dll }}\right)$ foram estimados através de um circuito elétrico equivalente.

\section{c) Curva de polarização potenciodinâmicas anódicas e catódicas $\left(C_{p o l}\right)$}

As curvas de polarização potenciodinâmicas anódicas e catódicas foram obtidas imediatamente após o espectro de EIE. A faixa de potencial foi de $-300 \mathrm{mV}$ em relação ao potencial de corrosão a $+300 \mathrm{mV}$ versus eletrodo de referência. $A$ velocidade de varredura utilizada foi de $1 \mathrm{mV} . \mathrm{s}^{-1}$.

Todo estudo foi desenvolvido em meio naturalmente aerado e a temperatura ambiente.

Para os ensaios eletroquímicos foram utilizados os equipamentos potenciostato EG\&G Princeton Applied Reseach 273A conectado a com um analisador de freqüência Solatron SI 1255HF.

Para as medidas de $\mathrm{E}_{\text {corr }}$ e $\mathrm{C}_{\text {pol }}$ foi utilizado o software 352 SoftCorr III e para as medidas de EIE foram utilizados os software Zplot e Zview 3.0. 


\section{RESULTADOS E DISCUSSÕES}

O estudo foi iniciado com a obtenção da taxa de corrosão do aço-carbono ABNT 1005 em água do mar natural e em meio de $\mathrm{NaCl} 3,5 \%$. A técnica utilizada para este estudo foi o ensaio de imersão com medida de perda de massa. Com os valores encontrados foi possível verificar que, ao longo do tempo de imersão, a velocidade de corrosão do aço-carbono em meio de água do mar natural e em meio de $\mathrm{NaCl} 3.5 \%$ é decrescente até alcançar um valor constante.

Dando prosseguimento, o trabalho foi desenvolvido em meio de $\mathrm{NaCl} 3,5 \%$. Para este estudo foram empregadas as técnicas de medidas de potencial de corrosão, espectroscopia de impedância eletroquímica e levantamento de curvas de polarização potenciodinâmicas anódicas e catódicas, na ausência e presença das substâncias estudadas como inibidores de corrosão que foram: molibdato de sódio $\left(\mathrm{Na}_{2} \mathrm{MoO}_{4}\right)$; tungstato de sódio $\left(\mathrm{Na}_{2} \mathrm{WO}_{4}\right)$, e; copolímero a base de silano (CPPM).

Os resultados obtidos das técnicas empregadas com a presença das três substâncias estudadas são apresentados e discutidos seqüencialmente. Ao final do tratamento dos resultados, estimou-se a eficiência de cada substância estudada como inibidor de corrosão. Também foi estimada a perda de espessura do açocarbono ABNT 1005 em ausência e presença das diferentes substâncias estudadas.

\subsection{Ensaios de imersão com medida de perda de massa}

Os resultados de velocidade de corrosão ( $\left.V_{\text {corr }}\right)$ para o aço-carbono ABNT 1005 em meio de água do mar na ausência das substâncias estudadas como inibidores de corrosão são apresentados na Tabela 4.1.

A perda de espessura (P.E.) foi calculada de acordo com a eq. (5), que é dada por:

$$
\text { P.E. }=V_{\text {corr }} \times \frac{1}{\rho} \times(\text { f.c.u.P.E. })
$$


Onde: $\rho$ é a densidade do ferro $\left(7,85 \mathrm{~g} \cdot \mathrm{cm}^{-3}\right), V_{\text {corr é a velocidade de corrosão }}$ $\left(\mathrm{mg} . \mathrm{cm}^{-2} \cdot \mathrm{h}^{-1}\right)$, P.E. a perda de espessura $\left(\mathrm{mm} . \mathrm{ano}^{-1}\right)$ e f.c.u.P.E. é o fator de conversão de unidade $(8,064)$.

Tabela 4.1 - Valores da velocidade de corrosão $V_{\text {corr }}$ e perda de espessura P.E. do aço-carbono ABNT 1005 em água do mar natural e em meio de $\mathrm{NaCl} 3,5 \%$ com o tempo de imersão.

\begin{tabular}{cccc}
\hline $\begin{array}{c}\text { Tempo de } \\
\text { imersão } \\
(\mathrm{h})\end{array}$ & Meio & $\boldsymbol{V}_{\text {Corr }}\left(\mathbf{m g} \cdot \mathbf{c m}^{-2} \cdot \mathbf{h}^{-1}\right)$ & P.E. $\left(\mathbf{m m} \cdot \mathbf{a n o} \mathbf{-}^{-1}\right)$ \\
\hline \multirow{2}{*}{100} & Água do Mar & $(6,0 \pm 0,8) \cdot 10^{-3}$ & $6,7 \cdot 10^{-2}$ \\
& $\mathrm{NaCl} 3,5 \%$ & $(7,5 \pm 2,5) \cdot 10^{-3}$ & $8,4.10^{-2}$ \\
\hline \multirow{2}{*}{800} & Água do Mar & $(6,4 \pm 1,1) \cdot 10^{-3}$ & $7,1 \cdot 10^{-2}$ \\
& $\mathrm{NaCl} 3,5 \%$ & $(11,0 \pm 3,0) \cdot 10^{-3}$ & $1,2 \cdot 10^{-1}$ \\
\hline 2300 & $\mathrm{NaCl} 3,5 \%$ & $(7,2 . \pm 1,4) \cdot 10^{-3}$ & $8,0.10^{-2}$ \\
\hline
\end{tabular}

Em meio de água do mar a velocidade de corrosão encontrada foi de $0,006 \mathrm{mg} \cdot \mathrm{cm}^{-2} \mathrm{~h}^{-1}$, que corresponde a uma perda de espessura de 0,071 $\mathrm{mm}$ por ano; enquanto que em meio de $\mathrm{NaCl} 3,5 \%$ a velocidade de corrosão foi de $0,007 \mathrm{mg} \cdot \mathrm{cm}^{-2} \mathrm{~h}^{-1}$, que corresponde a uma perda de espessura de $0,080 \mathrm{~mm}$ por ano. Comparando os valores obtidos com os valores de perda de espessura do açocarbono em meio de água do mar encontrados na literatura, que variam de 0,06 mm por ano a 0,12 mm por ano (LAQUE, 1948 apud SHREIR, 1994; CORROSÃO, 1997), observa-se que os valores obtidos ficaram no mínimo da faixa esperada.

Como o erro na determinação da velocidade de corrosão em meio de $\mathrm{NaCl}$ $3,5 \%$ foi muito alto (cerca de $30 \%$ ) fica difícil estabelecer diferenças significativas com a velocidade de corrosão para o meio de água do mar, mas é possível observar que a tendência da velocidade de corrosão do aço-carbono ABNT 1005 ser menor em meio água do mar, aproximadamente $16 \%$ menor. Logo, os equipamentos construídos com aço-carbono ABNT 1005 e expostos em meio de $\mathrm{NaCl} 3,5 \%$ devem ser protegidos contra a corrosão ou construídos com uma espessura maior, o que pode ser economicamente menos viável do que a proteção contra a corrosão. 


\subsection{Medidas de potencial de corrosão}

Os valores das medidas de potencial de corrosão $\left(E_{\text {corr }}\right)$ que foram obtidos para o aço-carbono ABNT 1005 em meio de $\mathrm{NaCl}$ 3,5\% na ausência e presença de diferentes concentrações das substâncias estudadas como inibidores de corrosão, para os tempos de imersão de 3 horas, 6 horas, 12 horas e 24 horas estão apresentados na Tabela 4.2.

Dos resultados apresentados na Tabela 4.2 observa-se que em meio de $\mathrm{NaCl}$ 3,5\%, na ausência das substâncias estudadas como inibidores de corrosão, o potencial de corrosão estabilizou-se em torno de $700 \mathrm{mV}$ com 3 horas de imersão.

A presença no meio de molibdato de sódio $\left(\mathrm{Na}_{2} \mathrm{MoO}_{4}\right)$ deslocou os potenciais de corrosão para valores mais positivos. Esse resultado é provavelmente devido à adsorção dos íons de molibdato na superfície do aço, formando um filme nos sítios anódicos, tornando-o menos ativo (VUKASOVICH; FARR, 1986).

Tabela 4.2 - Valores de potencial de corrosão para o aço-carbono ABNT 1005 em meio de $\mathrm{NaCl}$ $3,5 \%$, na ausência e presença das substâncias estudadas como inibidores de corrosão e para tempo de imersão de 3 horas, 6 horas, 12 horas e 24 horas.

\begin{tabular}{|c|c|c|c|c|c|c|c|c|c|c|}
\hline \multirow{3}{*}{$\begin{array}{l}\text { tempo } \\
\text { (h) }\end{array}$} & \multicolumn{10}{|c|}{$E_{\text {corr }}(\mathrm{mV})$} \\
\hline & \multirow{2}{*}{$\begin{array}{l}\text { Sem } \\
\text { Inib }\end{array}$} & \multicolumn{3}{|c|}{$\mathrm{Na}_{2} \mathrm{MoO}_{4}\left(\mathrm{~mol}^{-\mathrm{L}^{-1}}\right)$} & \multicolumn{3}{|c|}{$\mathrm{Na}_{2} \mathrm{WO}_{4}\left(\mathrm{~mol}^{-\mathrm{L}^{-1}}\right)$} & \multicolumn{3}{|c|}{ CPPM (mol. $\left.\mathrm{L}^{-1}\right)$} \\
\hline & & $1 \times 10^{-3}$ & $5 \times 10^{-3}$ & $1 \times 10^{-2}$ & $1 \times 10^{-3}$ & $5 \times 10^{-3}$ & $1 \times 10^{-2}$ & $5 \times 10^{-5}$ & $1 \times 10^{-4}$ & $5 \times 10^{-4}$ \\
\hline 0 & -660 & -615 & -415 & -360 & -635 & -386 & -411 & -668 & -650 & -624 \\
\hline 3 & -700 & -616 & -472 & -418 & -687 & -447 & -397 & -678 & -690 & -689 \\
\hline 6 & -696 & -595 & -472 & -422 & -686 & -437 & -388 & -690 & -690 & -686 \\
\hline 12 & -696 & -612 & -491 & -439 & -688 & -501 & -401 & -690 & -684 & -679 \\
\hline 24 & -694 & -609 & -491 & -449 & -690 & -651 & -651 & -690 & -681 & -679 \\
\hline
\end{tabular}

Analisando os resultados obtidos para tempos crescentes de imersão na presença do molibdato de sódio, observa-se que para maiores concentrações estes 
valores de potenciais tornam-se mais negativos, embora ainda sejam mais positivos em relação aos valores sem inibidor. Este comportamento pode ser explicado supondo que com o passar do tempo os íons de molibdato adsorvidos devem estar competindo com os íons de cloreto na superfície do aço. O comportamento dos potenciais de corrosão para o meio com o $\mathrm{Na}_{2} \mathrm{WO}_{4}$ é semelhante aquele observado para $\circ \mathrm{Na}_{2} \mathrm{MoO}_{4}$.

$\mathrm{O}$ comportamento dos potenciais de corrosão em presença de $\mathrm{Na}_{2} \mathrm{MoO}_{4} \mathrm{e}$ $\mathrm{Na}_{2} \mathrm{WO}_{4}$, em relação aquele obtido na ausência destas, indica que as substâncias estudadas devem comportar-se como inibidores anódicos.

Finalmente, os resultados de potencias de corrosão para o meio com o CPPM praticamente não são alterados em relação aos valores obtidos na ausência destas.

\subsection{Espectroscopia de impedância eletroquímica (EIE)}

\subsubsection{Resultados de EIE para o aço-carbono ABNT 1005 em meio de $\mathrm{NaCl} 3,5 \%$ para tempos crescentes de imersão}

Na Figura 4.1 são apresentados os diagramas de impedância para o açocarbono ABNT 1005 obtidos para tempos de imersão de 3 horas, 6 horas, 12 horas e 24 horas, em meio de $\mathrm{NaCl} 3,5 \%$. Analisando qualitativamente todos os diagramas de Nyquist apresentados (Fig. 4.1a), observa-se para todos os tempos de imersão a presença de apenas um arco capacitivo. Também é possível observar que para 6 horas de imersão o diâmetro do arco capacitivo diminui, voltando a aumentar para tempos maiores de imersão. Este resultado permite supor que a camada de óxido formada sobre a superfície do aço, além de ser muito fina não deve ser homogênea, e, portanto, deve ocorrer a penetração do eletrólito, diminuindo o diâmetro do arco capacitivo e a resistência à transferência de carga, $R_{t c}$. Para tempos de imersão de 12 horas e 24 horas o filme de óxido formado parece ser menos poroso e muito provavelmente mais espesso. Esta suposição é baseada no aumento do diâmetro dos arcos capacitivos. 


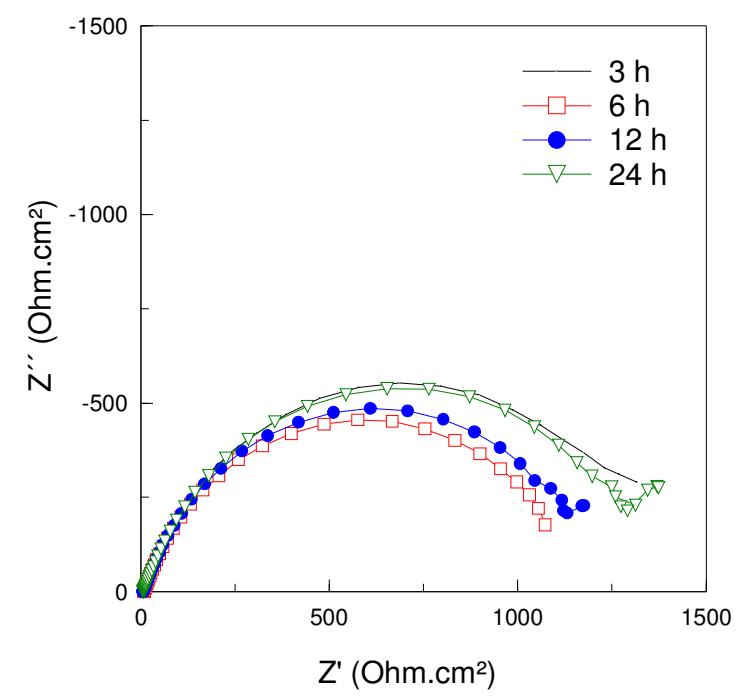

a) Nyquist

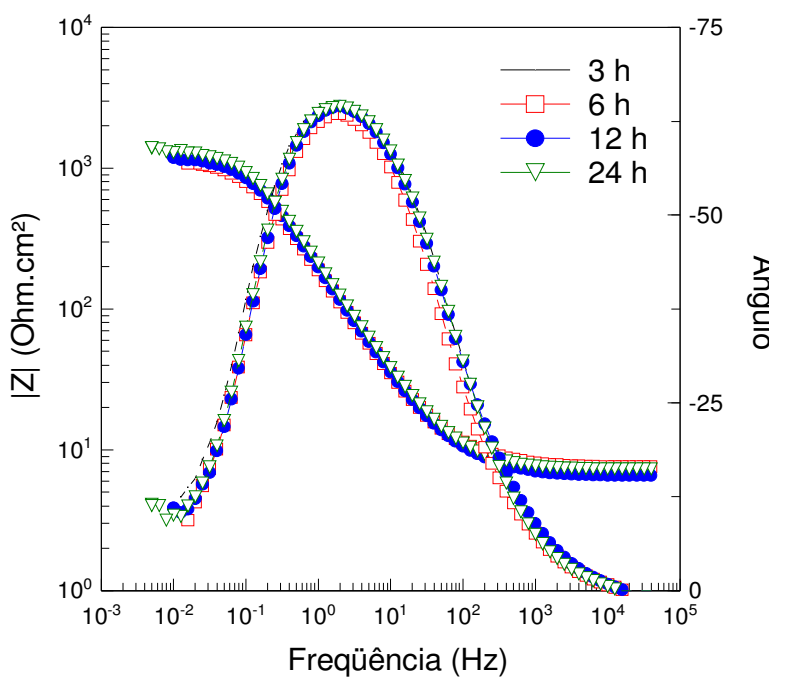

b) Bode

Figura 4.1 - Impedância eletroquímica para o aço-carbono ABNT 1005 em NaCl 3,5\% na ausência das substâncias estudadas como inibidores de corrosão.

Os diagramas de Bode (Fig. 4.1b) indicam que os módulos da impedância $(|Z|)$ e os ângulos de fase $(\theta)$, praticamente não foram alterados.

Segundo Bonora e colaboradores (1995), Jorcin (2006) e Schaftinghen (2004) para quantificar os parâmetros de impedância eletroquímica e estudar os fenômenos envolvidos é necessário fazer uso da associação destes parâmetros a circuitos elétricos equivalentes. Pelos resultados obtidos neste trabalho é possível observar apenas uma constante de tempo bem definida. De acordo com Schaftinghen (2004) o circuito elétrico equivalente que melhor representa este sistema é apresentado na Figura 4.2.

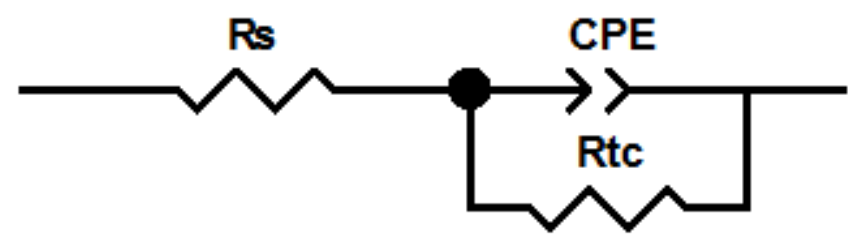

Figura 4.2 - Circuito elétrico equivalente para a representação do sistema estudado.

Com a Figura 4.2 é possível quantificar os parâmetros: $R_{s}$ (resistência da solução), $R_{t c}$ (resistência à transferência de carga), e um elemento de constante de 
fase (CPE). O CPE do sistema não corresponde exatamente à capacitância pura e pode ser discutido em termo dos fenômenos de difusão e morfologia da superfície (BONORA et al., 1995). Os valores dos módulos da impedância $|Z|$ e dos ângulos de fase $\theta$, foram tirados diretamente dos diagramas.

O cálculo da capacitância da dupla camada elétrica $\left(C P E_{d l}\right)$ é realizado com o auxílio da equação (6), sendo $\mathrm{y}_{0}=\mathrm{CPE}-\mathrm{T}$ e $\alpha=\mathrm{CPE}-\mathrm{P}$.

$$
C P E_{d l}=y_{o}\left(\omega_{\max }\right)^{\alpha-1}(6)
$$

Os valores de CPE-T e CPE-P correspondem aos elementos de fase constante (identificados através do software Zview) e $\omega_{\text {máx }}$ corresponde a freqüência no ponto de máximo valor do eixo imaginário (HSU; MANSFELD, 2001)

$\mathrm{Na}$ Tabela 4.3 são apresentados os parâmetros de espectroscopia de impedância eletroquímica que foram obtidos a partir do ajuste dos resultados (Fig. 4.2) ao circuito elétrico equivalente para o aço-carbono ABNT 1005 em meio de $\mathrm{NaCl} 3,5 \%$ na ausência das substâncias estudadas como inibidores de corrosão.

Tabela 4.3 - Parâmetros estimados a partir do ajuste dos dados experimentais obtidos com o açocarbono ABNT 1005 em meio de $\mathrm{NaCl}$ 3,5\% na ausência das substâncias estudadas.

\begin{tabular}{c|cccc}
\hline \multirow{2}{*}{ Parâmetros } & \multicolumn{4}{|c}{ Tempo de imersão } \\
\cline { 2 - 5 } & $3 \mathrm{~h}$ & $6 \mathrm{~h}$ & $12 \mathrm{~h}$ & $24 \mathrm{~h}$ \\
\hline$R_{s} /\left(\mathrm{Ohm}_{\mathrm{cm}} \mathrm{cm}^{2}\right)$ & 6,4 & 7,8 & 6,8 & 7,4 \\
$C P E_{d l}\left(\mu \mathrm{F} . \mathrm{cm}^{-2} \cdot \mathrm{s}^{(\alpha-1)}\right)$ & 453 & 417 & 421 & 350 \\
$\alpha$ & 0,80 & 0,79 & 0,80 & 0,78 \\
$R_{t c} /\left(\mathrm{Ohm}_{\mathrm{cm}} \mathrm{cm}^{2}\right)$ & 1487 & 1239 & 1356 & 1453 \\
$|Z| /\left(\mathrm{Ohm}_{\mathrm{cm}}{ }^{2}\right)$ & 1348 & 1088 & 1198 & 1401 \\
$\theta$ & $65^{\circ}$ & $63^{\circ}$ & $64^{\circ}$ & $64^{\circ}$ \\
\hline
\end{tabular}

Os valores encontrados do módulo da impedância (|Z|) e ângulo de fase $(\theta)$, Tabela 4.3, praticamente não são alterados com o tempo de imersão, de acordo com o observado na Figura 4.2. No entanto, os valores da capacitância da dupla camada elétrica $\left(C P E_{d l}\right)$ são levemente diminuídos com o tempo de imersão. Os valores de $\alpha$ 
são praticamente iguais para todos os tempos, ou seja, em torno de 0,8 , indicando que o filme de óxido formado é poroso. Estes resultados confirmam que o óxido formado sobre a superfície metálica praticamente não é alterado com o tempo de imersão. Os valores encontrados para $R_{S}$, apesar de apresentados, não serão levados em consideração, pois além de representarem menos de $1 \%$ da $R_{t c}$, estes parâmetros variam de acordo com a posição do eletrodo de referência.

\subsubsection{Resultados de EIE para o aço-carbono ABNT 1005 em meio de $\mathrm{NaCl} 3,5 \%$ na presença e ausência do $\mathrm{Na}_{2} \mathrm{MoO}_{4}$}

A Figura 4.3 apresenta os diagramas de impedância do aço-carbono ABNT 1005 que foram obtidos para tempo de imersão de 3 horas em meio de $\mathrm{NaCl} 3,5 \%$ na ausência e presença de $\mathrm{Na}_{2} \mathrm{MoO}_{4}$.

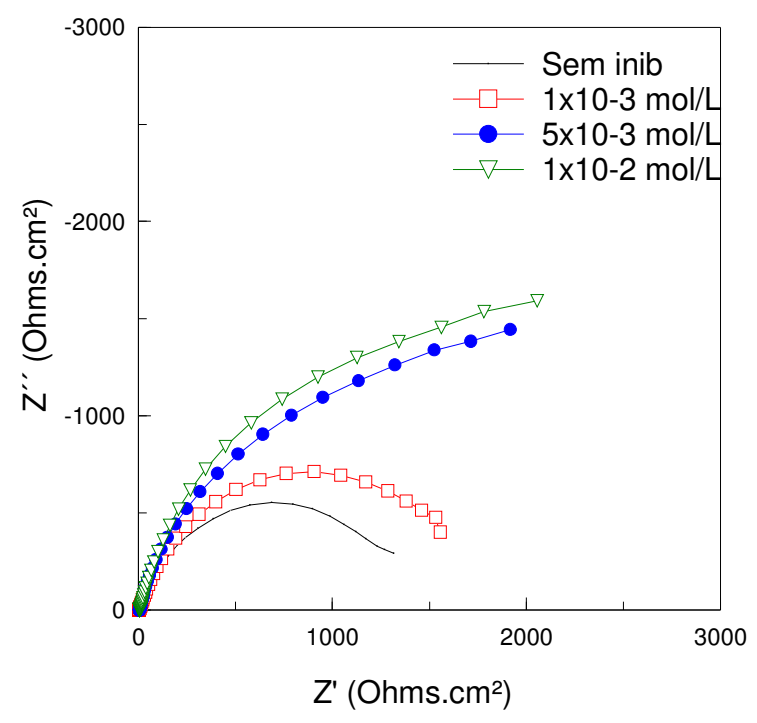

a) Nyquist

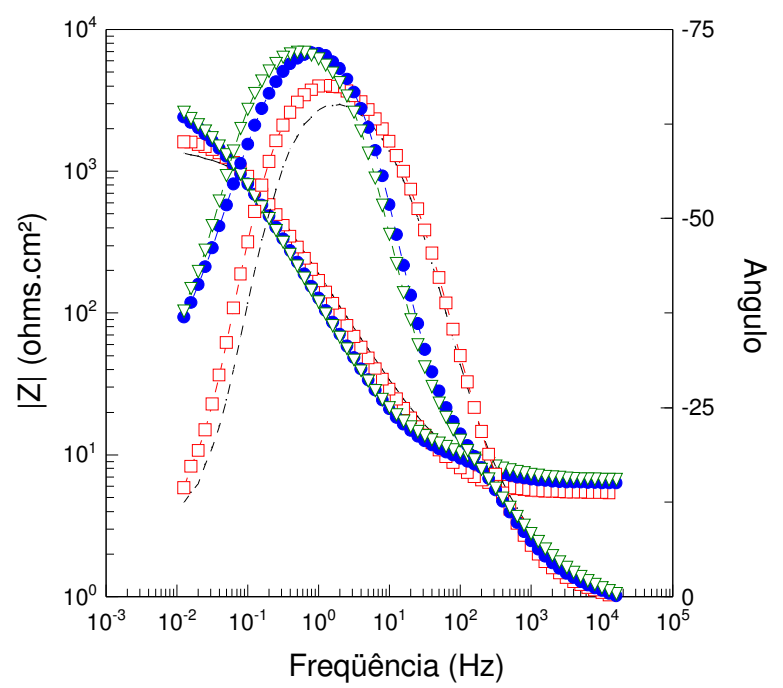

b) Bode

Figura 4.3 - Diagramas de impedância para o aço-carbono ABNT 1005 obtidos com 3 horas de imersão em meio de $\mathrm{NaCl} 3,5 \%$ na ausência e presença de $\mathrm{Na}_{2} \mathrm{MoO}_{4}$.

Analisando qualitativamente os resultados apresentados nos diagramas de Nyquist (Fig. 4.3a) observa-se a presença de apenas um arco capacitivo bem definido para todas as concentrações de $\mathrm{Na}_{2} \mathrm{MoO}_{4}$ estudadas. Também é possível observar que o diâmetro do arco capacitivo aumenta com o aumento da concentração do $\mathrm{Na}_{2} \mathrm{MoO}_{4}$. 
De acordo com Saremi, Dehghanian e Sabet (2006) o íon molibdato pode ser quimicamente adsorvido na camada de óxido de ferro formado sobre o metal, auxiliando na formação de um composto químico protetor tal como o molibdato de ferro. Com esta análise é possível supor que, aumentando-se a concentração do $\mathrm{Na}_{2} \mathrm{MoO}_{4}$ no meio, a quantidade de molibdato quimicamente adsorvida na camada de óxido também aumente, tornado-a mais espessa, menos porosa e, portanto, mais protetora.

Os diagramas de Bode (Fig. 4.3b) indicam que os módulos da impedância $(|Z|)$ e os ângulos de fase $(\theta)$ também são crescentes com 0 aumento da concentração de molibdato de sódio.

Para quantificar os parâmetros de impedância eletroquímica e discutir os fenômenos envolvidos, foi utilizado o circuito elétrico equivalente apresentado na Figura 4.2. O cálculo da eficiência das substâncias estudadas como inibidores de corrosão foi feito com auxílio da eq. (7), onde: $R_{t c}$ e $R_{\text {tcseminh }}$ são, respectivamente, as resistências à transferência de carga com inibidor e sem inibidor.

$$
\eta=\frac{R_{t c}-R_{t_{\text {csen minib }}}}{R_{t c}} x 100 \%
$$

Os parâmetros $R_{s}, C P E_{d l}$ (capacitância da dupla camada elétrica) e $R_{t c}$, obtidos a partir do ajuste do circuito elétrico equivalente, além dos valores do módulo da impedância $(|Z|)$, do ângulo de fase $(\theta)$ e da eficiência $(\eta)$ do molibdato de sódio como inibidor de corrosão são apresentados na Tabela a seguir . 
Tabela 4.4 - Parâmetros estimados a partir do ajuste dos dados experimentais obtidos com o açocarbono ABNT 1005 por 3 horas de imersão em meio de $\mathrm{NaCl} 3,5 \%$ na ausência e presença de $\mathrm{Na}_{2} \mathrm{MoO}_{4}$.

\begin{tabular}{c|cccc}
\hline \multirow{2}{*}{ Parâmetros } & \multicolumn{4}{|c}{ Concentração de $\mathrm{Na}_{2} \mathrm{MoO}_{4}\left(\mathrm{~mol}^{-1}\right)$} \\
\cline { 2 - 5 } & 0,00 & $1 \times 10^{-3}$ & $5 \times 10^{-3}$ & $1 \times 10^{-2}$ \\
\hline$R_{s} /\left({\left.\mathrm{Ohm} . \mathrm{cm}^{2}\right)}^{2}\right.$ & 6,4 & 5,5 & 6,9 & 7,6 \\
$C P E_{d l}\left(\mu \mathrm{F} . \mathrm{cm}^{-2} \cdot \mathrm{s}^{(\alpha-1)}\right)$ & 453 & 552 & 1098 & 1108 \\
$\alpha$ & 0,80 & 0,81 & 0,81 & 0,82 \\
$R_{t c} /\left(\mathrm{Ohm} \cdot \mathrm{cm}^{2}\right)$ & 1487 & 1901 & 3644 & 4078 \\
$|Z| /\left(\mathrm{Ohm} \cdot \mathrm{cm}^{2}\right)$ & 1348 & 1607 & 2400 & 2600 \\
$\theta$ & $65^{\circ}$ & $68^{\circ}$ & $71 \%$ & $72^{\circ}$ \\
$\eta$ & --- & $22 \%$ & $59 \%$ & $63 \%$ \\
\hline
\end{tabular}

Pela Tabela 4.4, verifica-se que a resistência à transferência de carga aumenta para concentrações crescentes de molibdato de sódio. Observa-se também que os valores de resistência à transferência de carga, $R_{t c}$, são crescentes com o aumento da concentração de molibdato de sódio, ou seja, para uma concentração de $1 \times 10^{-2}$ mol.L ${ }^{-1}$ de molibdato de sódio, o valor de $R_{t c}$ é em torno de três vezes maior do que na ausência desta. Este comportamento indica que o filme formado com a presença do íon molibdato sobre a superfície metálica torna-se mais protetor para a concentração crescente deste íon no meio. Também se verifica que a capacitância da dupla camada elétrica $C P E_{d l}$, aumenta, indicando que provavelmente deve haver uma forte interação entre o íon $\mathrm{MoO}_{4}{ }^{2-}$ e o óxido formado na superfície do aço. Os valores de $\alpha$ são praticamente iguais, porém torna-se maior para a concentração de $1 \times 10^{-2} \mathrm{~mol}^{-L^{-1}}$, indicando que o filme formado torna-se menos poroso com a presença do molibdato de sódio, embora a porosidade ainda seja elevada. Estes resultados são concordantes com aqueles encontrados por Bentley et al (1986). No entanto, a redução dos processos corrosivos pode ser evidenciada pelos valores crescentes do módulo da impedância $(|Z|)$ e ângulo de fase $(\theta)$, para concentrações crescentes de molibdato de sódio. Com os valores de $R_{t c}$ foi possível calcular a eficiência do molibdato de sódio, cujos valores são crescentes para concentrações crescentes de molibdato de sódio. 
Os diagramas de impedância que mostram a evolução do comportamento da inibição da corrosão do aço-carbono, em meio de $\mathrm{NaCl} 3,5 \%$, com $1 \times 10^{-2} \mathrm{~mol}^{-L^{-1}}$ de molibdato de sódio, para tempos crescentes de imersão são apresentados na Figura 4.4 .

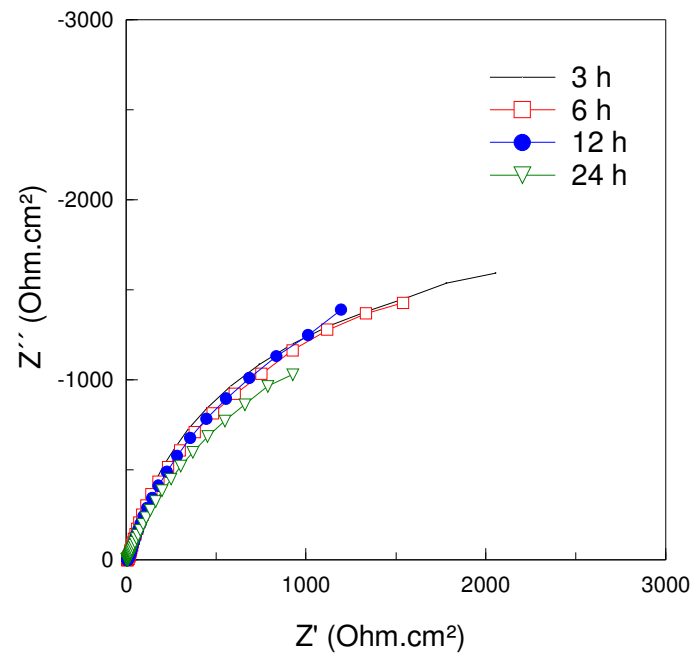

a) Nyquist

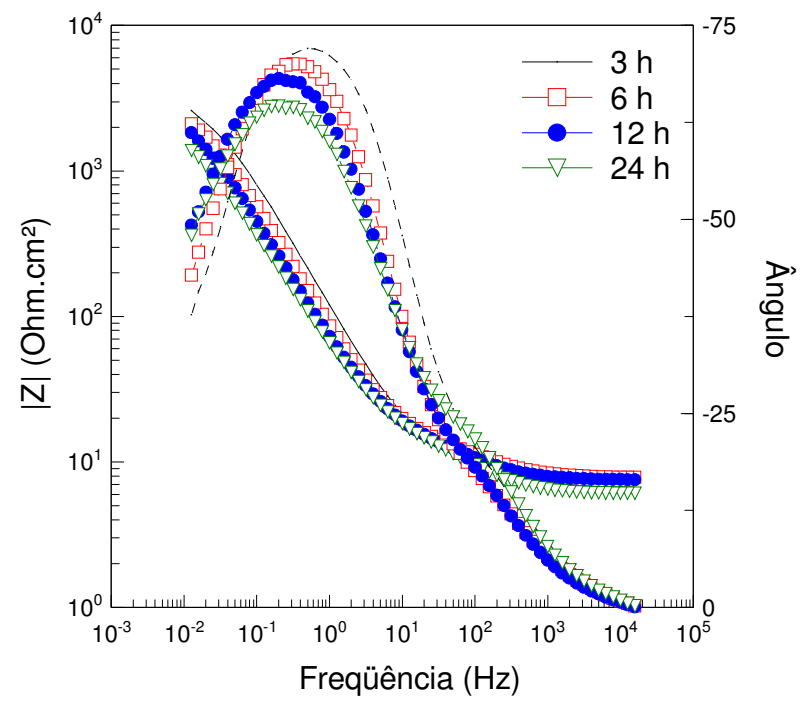

b) Bode

Figura 4.4 - Evolução dos diagramas de impedância para o aço-carbono ABNT 1005 obtidos em $\mathrm{NaCl} 3,5 \%$ com $1 \times 10^{-2} \mathrm{~mol}^{-1} \mathrm{~L}^{-1}$ de $\mathrm{Na}_{2} \mathrm{MoO}_{4}$ o tempo de imersão.

Pela Figura 4.4a observa-se para todos os tempos de imersão à formação de apenas um arco capacitivo bem definido. Este comportamento é semelhante aquele observado na ausência de molibdato, para tempos crescentes de imersão, embora, a presença do molibdato tenha alterado de forma positiva os parâmetros tirados tanto dos diagramas de Bode, como pela simulação de circuitos elétricos equivalentes. Este comportamento deve estar relacionado com a adsorção do molibdato na camada de óxido, formando provavelmente o $\mathrm{FeMoO}_{4}$ (SAREMI et al., 2006). Para maiores tempos de imersão, a camada de óxido provavelmente torna-se mais espessa e não homogenia.

Para analisar quantitativamente os resultados foram ajustados ao circuito elétrico equivalente (Fig. 4.2). Os resultados obtidos são apresentados na Tabela 4.5 
Tabela 4.5 - Evolução com o tempo de imersão dos parâmetros estimados a partir do ajuste dos dados experimentais para o aço-carbono ABNT 1005 em meio de $\mathrm{NaCl} 3,5 \% \mathrm{com}$ $1 \times 10^{-2} \mathrm{~mol}^{-L^{-1}}$ de $\mathrm{Na}_{2} \mathrm{MoO}_{4}$.

\begin{tabular}{c|cccc}
\hline \multirow{2}{*}{ Parâmetros } & \multicolumn{4}{|c}{ Tempo de imersão } \\
\cline { 2 - 5 } & $3 \mathrm{~h}$ & $6 \mathrm{~h}$ & $12 \mathrm{~h}$ & $24 \mathrm{~h}$ \\
\hline$R_{s}\left(\mathrm{Ohm} \cdot \mathrm{cm}^{2}\right)$ & 7,6 & 8,8 & 7,5 & 6,0 \\
$C P E_{d l}\left(\mu \mathrm{F} . \mathrm{cm}^{-2} \cdot \mathrm{s}^{(\alpha-1)}\right)$ & 1108 & 1547 & 1433 & 1453 \\
$\alpha_{1}$ & 0,82 & 0,79 & 0,83 & 0,79 \\
$R_{1}\left(\mathrm{Ohm} \cdot \mathrm{cm}^{2}\right)$ & 4078 & 4185 & 4091 & 3380 \\
$|Z|\left(\mathrm{Ohm} \cdot \mathrm{cm}^{2}\right)$ & 2600 & 2100 & 1832 & 1385 \\
$\theta$ & $72^{\circ}$ & $70^{\circ}$ & $68^{\circ}$ & 64 而 \\
$\eta$ & $63 \%$ & $70 \%$ & $67 \%$ & $57 \%$ \\
\hline
\end{tabular}

Os resultados apresentados na Tabela 4.5 mostram que o tempo de imersão cujo resultado de eficiência foi maior, é de 6 horas. Esta afirmativa é justificada pelo fato da maior resistência à transferência de carga, $R_{t c}$. Observa-se também que para tempos maiores, isto é, 12 horas e 24 horas os valores de $R_{t c}$ e do módulo da impedância também diminui com o aumento do tempo de imersão. O resultado obtido com 6 horas de imersão não é compatível com o aumento da capacitância da dupla camada elétrica, $C P E_{d l}$, cujos resultados são crescentes. No entanto, o alto valor de $C P E_{d l}$, deve estar relacionado com as reações entre o molibdato de sódio e o óxido presente no filme (GUANNAN, 2006). Os valores de $\alpha$ oscilam entre 0,79 e 0,83 indicando que o filme formado é poroso.

\subsubsection{Resultados de EIE para o aço-carbono ABNT 1005 em meio de $\mathrm{NaCl} 3,5 \%$ na presença e ausência do $\mathrm{Na}_{2} \mathrm{WO}_{4}$}

A Figura 4.5 apresenta os diagramas de impedância para o aço-carbono ABNT 1005 obtidos com 3 horas de imersão em meio de $\mathrm{NaCl}$ 3,5\% na ausência e presença do tungstato de sódio $\left(\mathrm{Na}_{2} \mathrm{WO}_{4}\right)$. 


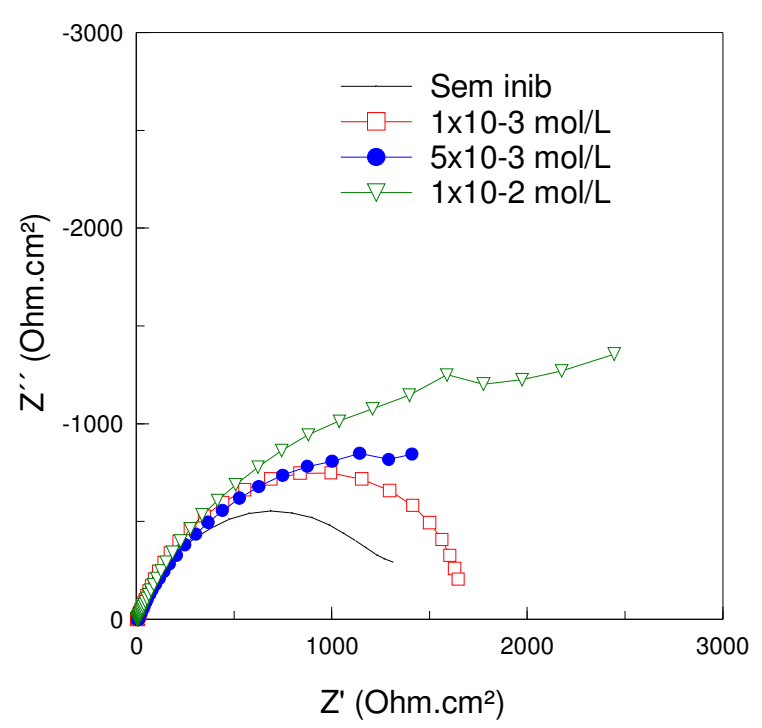

a) Nyquist

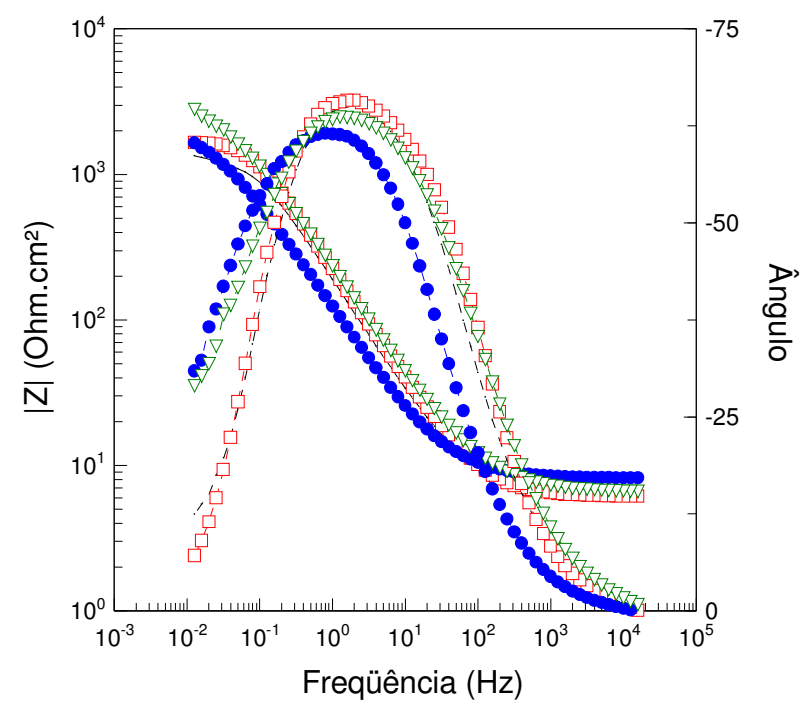

b) Bode

Figura 4.5 - Diagramas de impedância para o aço-carbono ABNT 1005 obtidos com 3 horas de imersão em meio de $\mathrm{NaCl} 3,5 \%$ na ausência e presença de $\mathrm{Na}_{2} \mathrm{WO}_{4}$.

Pelos diagramas apresentados (Fig. 4.5) é possível observar somente uma constante de tempo bem definida para todas as concentrações de tungstato de sódio estudadas. Também se observa que os diâmetros dos diagramas de Nyquist crescem com o aumento da concentração de tungstato de sódio. Através destas observações é possível sugerir que o íon tungstato deva reagir com a camada de óxido formada sobre a superfície do aço, tornando-a menos porosa e mais protetora, caso que é semelhante ao observado com a presença de molibdato de sódio. Pelos diagramas de Bode observam-se módulos de impedância e ângulos de fase crescentes com a concentração crescente de tungstato de sódio no meio.

Para quantificar os parâmetros de impedância eletroquímica, de acordo com Schaftinghen (2004), foi usado o circuito elétrico equivalente representado na Figura 4.2. Os parâmetros eletroquímicos de $R_{S}, C P E_{d l}$ (capacitância da dupla camada elétrica) e $R_{t c}$ foram obtidos a partir do ajuste do circuito elétrico equivalente, enquanto os valores do módulo da impedância $(|Z|)$, do ângulo de fase $(\theta)$ e a

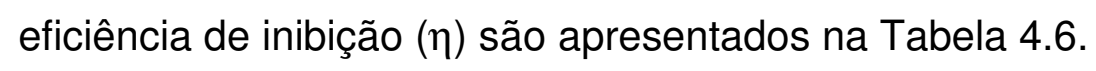


Tabela 4.6 - Parâmetros estimados a partir do ajuste dos dados experimentais obtidos com o açocarbono ABNT 1005 por 3 horas de imersão em meio de $\mathrm{NaCl} 3,5 \%$ na ausência e presença de $\mathrm{Na}_{2} \mathrm{WO}_{4}$.

\begin{tabular}{c|cccc}
\hline \multirow{2}{*}{ Parâmetros } & \multicolumn{4}{|c}{ Concentração de $\mathrm{Na}_{2} \mathrm{WO}_{4}\left(\mathrm{~mol}^{-1} \mathrm{~L}^{-1}\right)$} \\
\cline { 2 - 5 } & 0,00 & $1 \times 10^{-3}$ & $5 \times 10^{-3}$ & $1 \times 10^{-2}$ \\
\hline$R_{s}\left(\mathrm{Ohm} \cdot \mathrm{cm}^{2}\right)$ & 6,4 & 6,1 & 8,2 & 6,7 \\
$C P E_{d l}\left(\mu \mathrm{F} . \mathrm{cm}^{-2} \cdot \mathrm{s}^{(\alpha-1)}\right)$ & 453 & 390 & 1115 & 561 \\
$\alpha$ & 0,80 & 0,80 & 0,75 & 0,74 \\
$R_{t c}\left(\mathrm{Ohm} \cdot \mathrm{cm}^{2}\right)$ & 1487 & 1936 & 2490 & 3734 \\
$|Z|\left(\mathrm{Ohm} . \mathrm{cm}^{2}\right)$ & 1348 & 1659 & 1644 & 2796 \\
$\theta$ & $65^{\circ}$ & $66^{\circ}$ & $61^{\circ}$ & $63^{\circ}$ \\
$\eta$ & --- & $23 \%$ & $40 \%$ & $60 \%$ \\
\hline
\end{tabular}

Verifica-se na Tabela 4.6 que a resistência da solução, $R_{s}$, só é alterada com a concentração de $5 \times 10^{-3}$ de $\mathrm{Na}_{2} \mathrm{WO}_{4}$. A resistência à transferência de carga $\left(R_{t c}\right) \mathrm{e}$ o módulo da impedância $(|Z|)$ apresentam-se crescentes com o aumento da concentração de tungstato de sódio. Mesmo com a mais baixa concentração de tungstato de sódio, a resistência à transferência de carga, $R_{t c}$, é superior ao valor obtido na ausência das substâncias estudadas como inibidores de corrosão. $O$ ângulo de fase praticamente não foi alterado com a presença do tungstato de sódio. Observa-se que os valores de capacitância da dupla camada elétrica (CPE $\left.E_{d \prime}\right)$ tornam-se ligeiramente mais elevados. Verifica-se também que os valores de $\alpha$ variam entre 0,74 e 0,8 , indicando que o filme formado deve ser poroso. Com estas observações é possível supor que o aumento do valor da capacitância da dupla camada elétrica $\left(C P E_{d l}\right)$ possa estar associado à interação entre o tungstato de sódio e o óxido de ferro formado.

As eficiências apresentadas na Tabela 4.6 foram calculadas de acordo com a eq. (7), e pelos valores obtidos observa-se que a eficiência é crescente com o aumento da concentração do tungstato de sódio no meio, sugerindo que o filme formado com a presença do tungstato seja protetor. 
A seguir, na Figura 4.6, são apresentados os diagramas de impedância que mostram a evolução do comportamento da inibição da corrosão com o tempo de imersão em meio de $\mathrm{NaCl} 3,5 \%$ com $1 \times 10^{-2}$ mol. $\mathrm{L}^{-1}$ de $\mathrm{Na}_{2} \mathrm{WO}_{4}$.

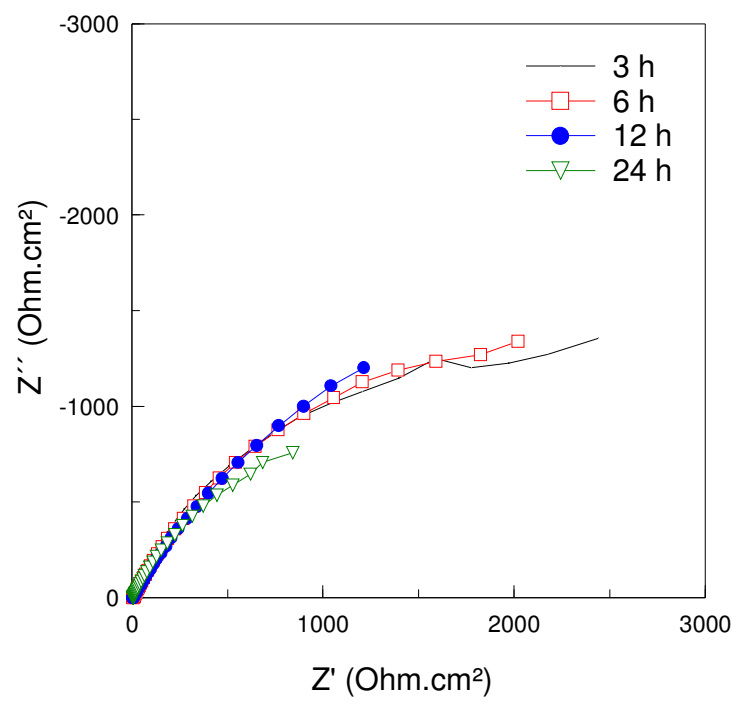

a) Nyquist

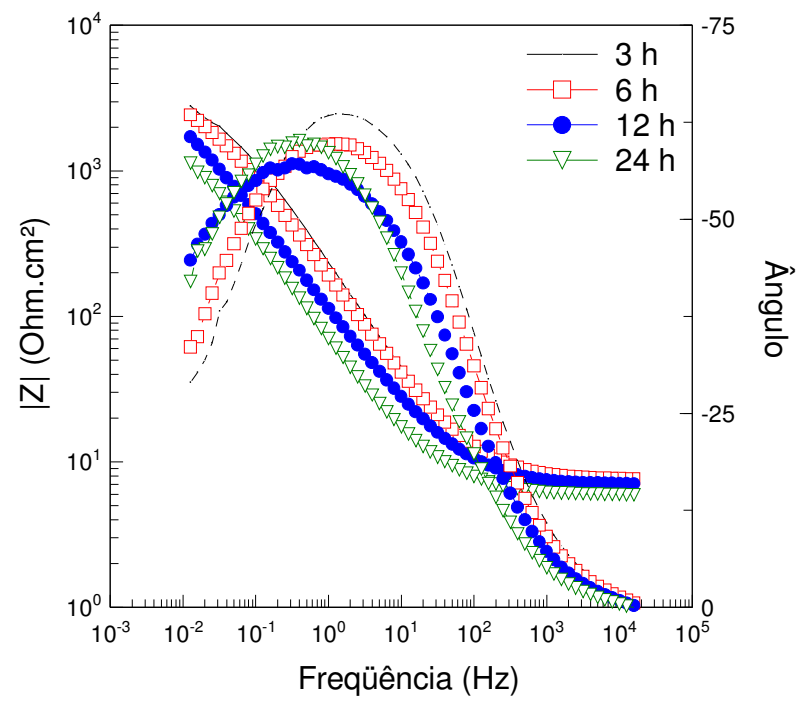

b) Bode

Figura 4.6 - Diagramas de impedância para o aço-carbono ABNT 1005 obtidos em meio de $\mathrm{NaCl}$ $3,5 \%$ com $1 \times 10^{-2} \mathrm{~mol}^{-L^{-1}}$ de $\mathrm{Na}_{2} \mathrm{WO}_{4}$ com o tempo de imersão.

Observa-se na Figura 4.6a, que o diâmetro dos diagramas de Nyquist diminui com o tempo de imersão. Os diagramas de Bode, (Fig. 4.6b) mostram que o módulo da impedância e o ângulo de fase são decrescentes com o aumento do tempo de imersão.

A simulação dos resultados ao circuito elétrico equivalente da Figura 4.2, permitiu estimar os parâmetros de resistência da solução, resistência à transferência de carga e capacitância da dupla camada elétrica Os resultados são apresentados na Tabela 4.7. 
Tabela 4.7- Evolução com o tempo de imersão dos parâmetros estimados a partir do ajuste dos dados experimentais para o aço-carbono ABNT 1005 em meio de $\mathrm{NaCl} 3,5 \% \mathrm{com}$ $1 \times 10^{-2}$ mol. $^{-1}$ de $\mathrm{Na}_{2} \mathrm{WO}_{4}$.

\begin{tabular}{c|cccc}
\hline \multirow{2}{*}{ Parâmetros } & \multicolumn{4}{|c}{ Tempo de imersão } \\
\cline { 2 - 5 } & $3 \mathrm{~h}$ & $6 \mathrm{~h}$ & $12 \mathrm{~h}$ & $24 \mathrm{~h}$ \\
\hline$R_{s}\left(\mathrm{Ohm}_{\mathrm{cm}} \mathrm{cm}^{2}\right)$ & 6,7 & 7,6 & 7,0 & 6,0 \\
$C P E_{d l}\left(\mu \mathrm{F} . \mathrm{cm}^{-2} \cdot \mathrm{s}^{(\alpha-1)}\right)$ & 561 & 684 & 1144 & 1872 \\
$\alpha$ & 0,74 & 0,71 & 0,67 & 0,70 \\
$R_{t c}\left(\mathrm{Ohm} \cdot \mathrm{cm}^{2}\right)$ & 3734 & 4110 & 5800 & 2997 \\
$|Z|\left(\mathrm{Ohm} \cdot \mathrm{cm}^{2}\right)$ & 2796 & 2474 & 1708 & 1132 \\
$\theta$ & $63^{\circ}$ & $60^{\circ}$ & $57^{\circ}$ & $60^{\circ}$ \\
$\eta$ & $60 \%$ & $70 \%$ & $77 \%$ & $51 \%$ \\
\hline
\end{tabular}

Analisando os resultados apresentados na Tabela 4.7 observa-se que a

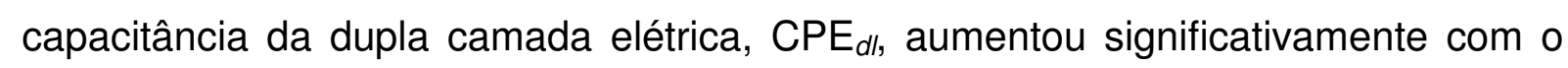
tempo de imersão e que os valores de $\alpha$ são muito baixos, em torno de 0,7 indicando que o filme de óxido deve apresentar porosidade elevada.

A resistência à transferência de carga, $R_{t c}$, apresenta-se crescente até 12 horas, o que implica no aumento da eficiência de inibição do $\mathrm{Na}_{2} \mathrm{WO}_{4}$. No entanto, para 24 horas o valor de $R_{t c}$ é $50 \%$ menor do que com 12 horas. O módulo da impedância, $|Z|$, apresenta comportamento decrescente com o aumento do tempo imersão. Com estas observações é possível concluir que com 12 horas de imersão parece ser a melhor situação para a inibição da corrosão do aço-carbono ABNT 1005 em meio de $\mathrm{NaCl} 3,5 \%$ com $1 \times 10^{-2} \mathrm{~mol}^{-L^{-1}}$ de tungstato de sódio. 


\subsubsection{Resultados de EIE para o aço-carbono ABNT 1005 em meio de $\mathrm{NaCl} 3,5 \%$ na presença e ausência do CPPM}

Os diagramas de impedância eletroquímica, que são apresentados a seguir Figura 4.7, foram obtidos com 3 horas de imersão em meio de $\mathrm{NaCl} 3,5 \%$ na ausência e presença do copolímero a base de silano (CPPM).

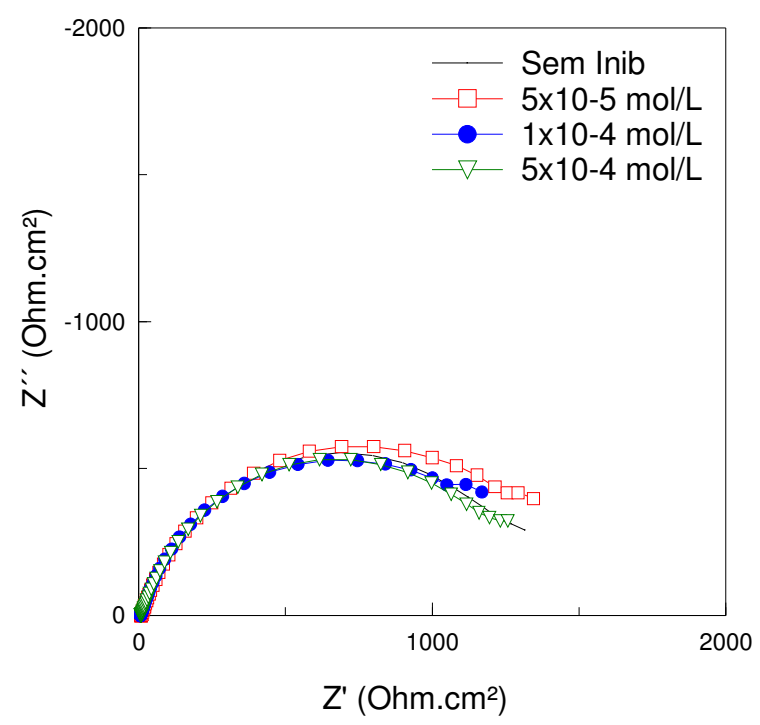

a) Nyquist

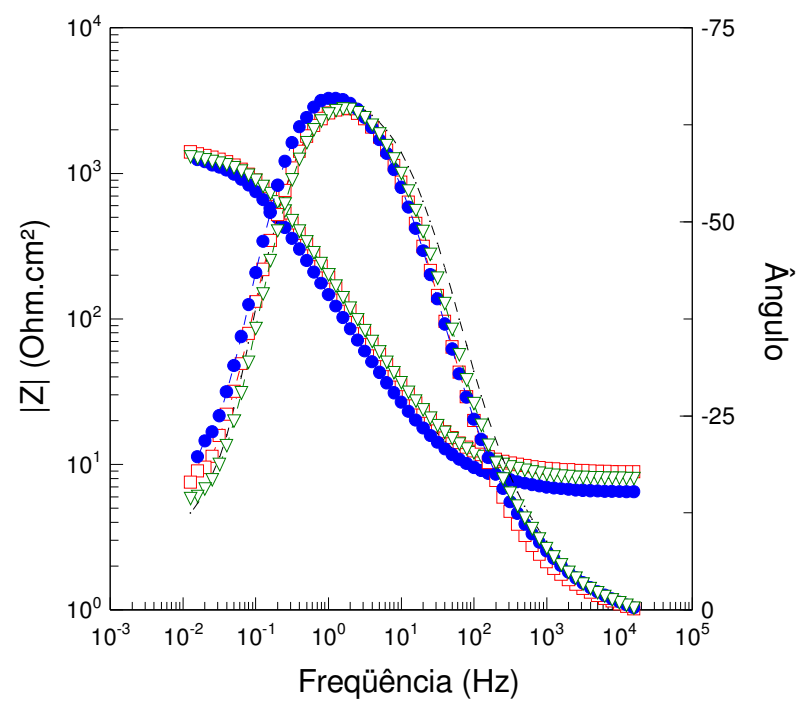

b) Bode

Figura 4.7 - Diagramas de impedância para o aço-carbono ABNT 1005 obtidos com 3 horas de imersão em meio de $\mathrm{NaCl} 3,5 \%$ na ausência e presença do CPPM.

Analisando a Figura 4.7 verifica-se que a presença do copolímero a base de silano, CPPM, não altera o diâmetro dos diagramas de Nyquist, além do módulo de impedância $|Z|$ e ângulos de fase, $\theta$, praticamente não serem alterados.

$\mathrm{Na}$ Tabela 4.8 são apresentados os valores de $R_{s}, C P E_{d l}$ e $R_{t c}$ que foram estimados a partir do ajuste dos resultados (Fig. 4.7) ao circuito elétrico equivalente (Fig. 4.2), além dos valores de eficiência de inibição da corrosão pelo CPPM, resultados que foram obtidos a partir da eq. (7). 
Tabela 4.8- Parâmetros estimados a partir do ajuste dos dados experimentais obtidos com o açocarbono ABNT 1005 por 3 horas de imersão em meio de $\mathrm{NaCl} 3,5 \%$ na ausência e presença do CPPM.

\begin{tabular}{c|cccc}
\hline \multirow{2}{*}{ Parâmetros } & \multicolumn{4}{|c}{ CPPM $\left(\mathrm{mol}^{-1} \mathrm{~L}^{-1}\right.$} \\
\cline { 2 - 5 } & 0,00 & $5 \times 10^{-5}$ & $1 \times 10^{-4}$ & $5 \times 10^{-4}$ \\
\hline$R_{s}\left(\mathrm{Ohm} \cdot \mathrm{cm}^{2}\right)$ & 6,4 & 9,0 & 6,9 & 8,3 \\
$C P E_{d l}\left(\mu \mathrm{F} . \mathrm{cm}^{-2} \cdot \mathrm{s}^{(\alpha-1)}\right)$ & 453 & 447 & 594 & 418 \\
$\alpha$ & 0,80 & 0,79 & 0,80 & 0,79 \\
$R_{t c}\left(\mathrm{Ohm} \cdot \mathrm{cm}^{2}\right)$ & 1487 & 1593 & 1436 & 1456 \\
$|Z|\left(\mathrm{Ohm} \cdot \mathrm{cm}^{2}\right)$ & 1348 & 1402 & 1242 & 1298 \\
$\theta$ & $65^{\circ}$ & $64^{\circ}$ & $65^{\circ}$ & $64^{\circ}$ \\
$\eta$ & --- & $6,7 \%$ & $-3,6 \%$ & $-2,1 \%$ \\
\hline
\end{tabular}

Avaliando quantitativamente os resultados dos parâmetros de impedância que são apresentados na Tabela 4.8, observa-se que a presença do CPPM em $\mathrm{NaCl}$ $3,5 \%$ não altera as características do produto de corrosão formado na superfície do aço-carbono ABNT 1005. Os valores de $\alpha$ são praticamente iguais para todos os tempos de imersão, que é em torno de 0,8 , indicando que o filme formado com a presença do CPPM é semelhante ao filme de óxido formado na ausência de inibidor. Todos os valores são muito próximos daqueles obtidos na ausência do CPPM. Assim, todos os resultados quantitativos são concordantes com a avaliação qualitativa da Figura 4.7.

Diante dos resultados obtidos com a presença do CPPM em meio de $\mathrm{NaCl}$ 3,5\% para aço-carbono ABNT 1005, não justificou estudar a evolução com o tempo de imersão. 


\subsection{Curva de polarização potenciodinâmicas anódicas e catódicas $\left(C_{p o l}\right)$}

A Figura 4.8 apresenta as curvas de polarização potenciodinâmicas anódicas e catódicas do aço-carbono ABNT 1005 em meio de $\mathrm{NaCl}$ 3,5\%, que foram obtidos na ausência de inibidores de corrosão. As curvas foram obtidas para tempos de imersão de 3 horas, 6 horas, 12 horas e 24 horas.

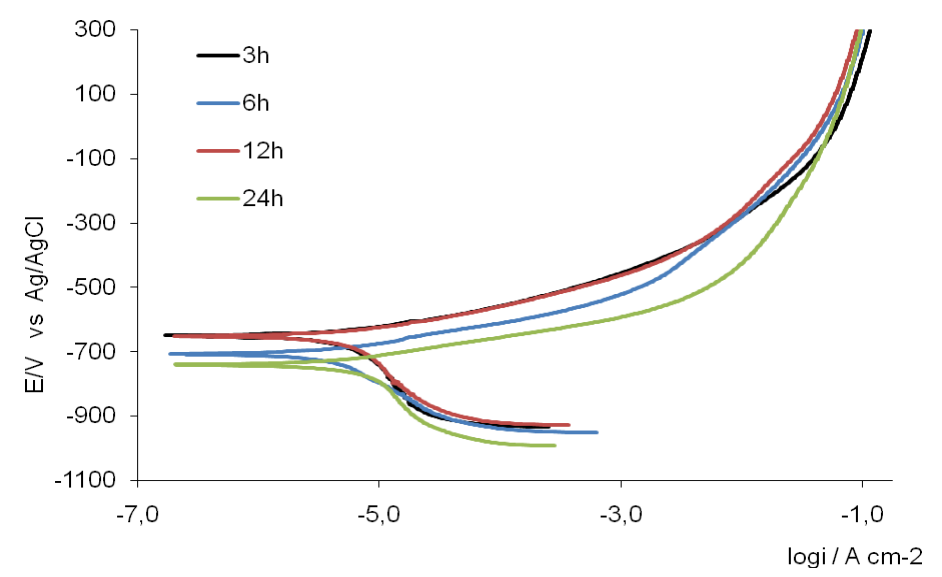

Figura 4.8 - Curvas de polarização potenciodinâmicas anódicas e catódicas para o aço-carbono ABNT 1005 em meio de $\mathrm{NaCl} 3,5 \%$.

Pela Figura 4.8 observa-se que o produto de corrosão formado sobre o açocarbono ABNT 1005 nas condições em que foi estudado deve ser poroso e pouco aderente. Esta afirmativa é baseada no fato de que o comportamento das curvas de polarização anódicas oscila com o tempo de imersão, devendo-se destacar que para o tempo de imersão de 24 horas a curva de polarização é despolarizada praticamente em toda faixa de potencial estudado. Estes resultados são também evidenciados pela alteração do potencial de corrosão.

Com o objetivo de verificar a perda de espessura do aço-carbono ABNT 1005 em meio de $\mathrm{NaCl}$ 3,5 \% foram obtidos as densidades de correntes de corrosão, $i_{\text {corr }}$ (Fig. 4.8). Os valores de $i_{\text {corr }}$ foram obtidos a partir da extrapolação da reta de Tafel anódica até o potencial de corrosão. O critério usado foi traçar uma reta ligando o ponto sobre a curva catódica, $50 \mathrm{mV}$ abaixo do $E_{c o r r}$ e estendê-la por uma década logarítmica. Finalmente a reta foi extrapolada até o potencial de corrosão, $E_{c o r r}$, onde se obteve o valor da densidade de corrente de corrosão, $i_{c o r r}$. 
Com os valores de $i_{\text {corr }}$ obtidos das curvas de polarização e com o auxílio da eq.(8), foram calculados os valores de velocidade de corrosão.

$$
V_{\text {corr }}=\frac{i_{\text {corr }} \cdot E_{q}}{F}
$$

Onde: $\mathrm{F}$ é a constante de Faraday, $96.500 \mathrm{C}$ por mol, e $E_{q}$ é o equivalente grama do ferro, $27,93 \mathrm{~g}$.

A perda de espessura (P.E.) foi calculada através da eq. (5)

A Tabela 4.9 apresenta os valores da densidade de corrente de corrosão, da velocidade de corrosão $\left(V_{\text {corr }}\right)$ e da perda de espessura do aço-carbono ABNT 1005 com o aumento do tempo de imersão.

Tabela 4.9 - Valores de densidade de corrente de corrosão, $i_{c o r r}$, velocidades de corrosão, $V_{\text {corr }}$ e perda de espessura, P.E., do aço-carbono ABNT 1005 em meio de $\mathrm{NaCl}$ 3,5\%.

\begin{tabular}{|c|c|c|c|}
\hline Tempo de imersão & $i_{\text {corr }}\left(\mathrm{A} . \mathrm{cm}^{-2}\right)$ & $V_{\text {Corr }}\left(\mathrm{mg} \cdot \mathrm{cm}^{-2} \cdot \mathrm{h}^{-1}\right)$ & P.E. $\left(\mathrm{mm}^{\mathrm{ano} \mathrm{o}^{-1}}\right)$ \\
\hline 3 horas & $5,0.10^{-6}$ & $5,2.10^{-3}$ & $5,8.10^{-2}$ \\
\hline 6 horas & $4,0.10^{-6}$ & $4,2.10^{-3}$ & $4,6.10^{-2}$ \\
\hline 12 horas & $5,0.10^{-6}$ & $5,2.10^{-3}$ & $5,8 \cdot 10^{-2}$ \\
\hline 24 horas & $7,1.10^{-6}$ & $8,2.10^{-3}$ & $9,0.10^{-2}$ \\
\hline
\end{tabular}

A Tabela 4.9 mostra que a perda de espessura do aço-carbono ABNT 1005 em meio de $\mathrm{NaCl} 3,5 \%$ reduz de 3 horas para 6 horas, porém após 6 horas a perda de espessura é crescente com o aumento do tempo de imersão.

As Figuras 4.9 e 4.10 apresentam as curvas de polarização potenciodinâmicas anódicas e catódicas na ausência e presença de molibdato de sódio com 6 horas de imersão e tungstato de sódio com 12 horas de imersão, respectivamente, nas concentrações de $5 \times 10^{-3} \mathrm{~mol}^{-L^{-1}} \mathrm{e} 1 \times 10^{-2} \mathrm{~mol} . \mathrm{L}^{-1}$.

A opção pelo tempo de imersão de 6 horas e 12 horas, respectivamente, e concentrações para obter as curvas de polarização está relacionada com os melhores resultados obtida com a técnica de impedância eletroquímica. 


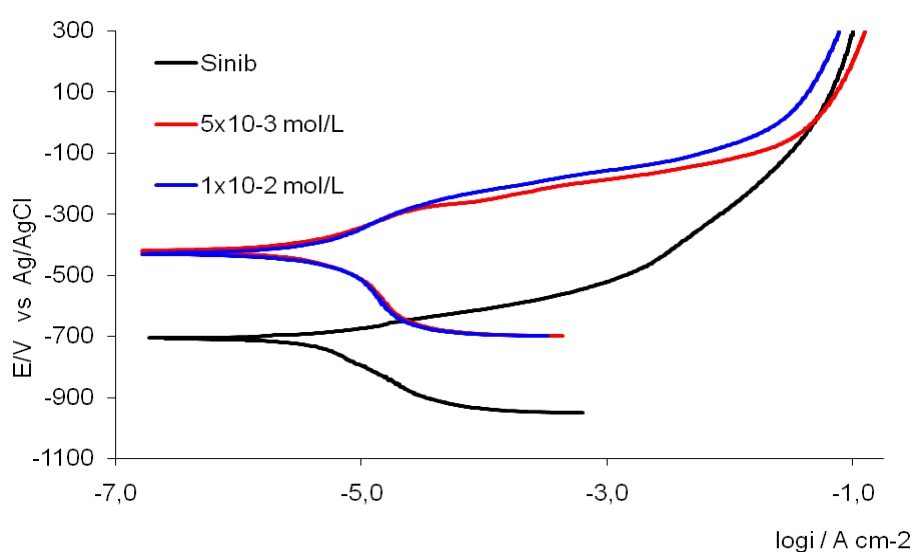

Figura 4.9 - Curvas de polarização potenciodinâmicas anódicas e catódicas para o aço-carbono ABNT 1005 em meio de $\mathrm{NaCl}$ 3,5\% na ausência e presença de $\mathrm{Na}_{2} \mathrm{MoO}_{4}$, com 6 horas de imersão.

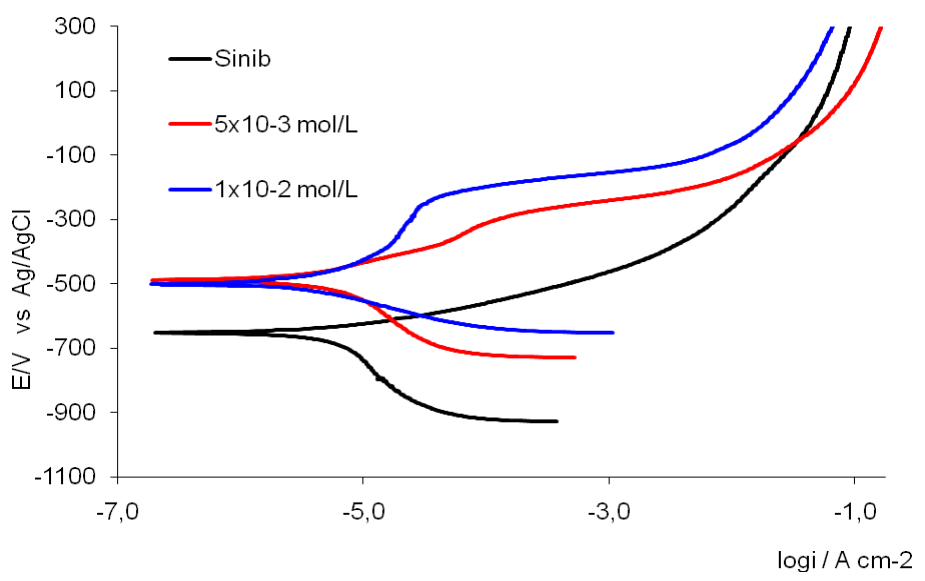

Figura 4.10 - Curvas de polarização potenciodinâmicas anódicas e catódicas para o aço-carbono ABNT 1005 em meio de $\mathrm{NaCl} 3,5 \%$ na ausência e presença de $\mathrm{Na}_{2} \mathrm{WO}_{4}$, com 12 horas de imersão.

As curvas de polarização apresentadas na Figura 4.9 mostram que a presença do molibdato de sódio polariza as curvas anódicas em relação aquela obtida na sua ausência de inibidor. Verifica-se que o potencial de corrosão para o meio na presença do molibdato de sódio é deslocado em torno de $250 \mathrm{mV}$ no sentido anódico. Observa-se ainda que nas concentrações de $5 \times 10^{-3} \mathrm{~mol}^{-L^{-1}} \mathrm{e}$ $1 \times 10^{-2} \mathrm{~mol}^{-L^{-1}}$ as curvas de polarização não são alteradas.

Na Figura 4.10 observa-se que a presença de tungstato de sódio torna as curvas anódicas mais polarizadas em relação à curva obtida na sua ausência, enquanto que as curvas catódicas foram despolarizadas. Este comportamento mostra que o tungstato de sódio age como inibidor anódico de corrosão 
A Tabela 4.10 reúne os valores de densidade de corrente de corrosão ( $\left.i_{\text {corr }}\right)$, da velocidade de corrosão $\left(V_{\text {corr }}\right)$ e da perda de espessura (P.E.) do aço-carbono ABNT 1005 sem e com a presença de $\mathrm{Na}_{2} \mathrm{MoO}_{4}$ e $\mathrm{Na}_{2} \mathrm{WO}_{4}$ com tempo de imersão de 6 horas e 12 horas de imersão, respectivamente.

Tabela 4.10 - Valores de densidade de corrente de corrosão, $i_{\text {corr }}$, velocidades de corrosão, $V_{\text {corr }}$ e perda de espessura, P.E., do aço-carbono ABNT $1005 \mathrm{em}$ meio de $\mathrm{NaCl} 3,5 \%$, na ausência e presença de $\mathrm{Na}_{2} \mathrm{MoO}_{4}$ (com 6 horas de imersão) e $\mathrm{Na}_{2} \mathrm{WO}_{4}$ (com 12 horas de imersão).

\begin{tabular}{|c|c|c|c|c|c|}
\hline Tempo & & io & $i_{c o r r}\left(\mathrm{~A} \mathrm{~cm}^{-2}\right)$ & $V_{\text {Corr }}\left(\mathrm{mg} \cdot \mathrm{cm}^{-2} \cdot \mathrm{h}^{-1}\right)$ & P.E. $\left(\mathrm{mm} . \mathrm{ano}^{-1}\right)$ \\
\hline \multirow{3}{*}{$6 \mathrm{~h}$} & \multicolumn{2}{|c|}{ Sem Inibidor } & $4,0.10^{-6}$ & $4,2.10^{-3}$ & $4,6 \cdot 10^{-2}$ \\
\hline & \multirow{2}{*}{ 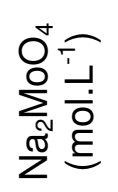 } & $5 \times 10^{-3}$ & $2,8 \cdot 10^{-6}$ & $2,9 \cdot 10^{-3}$ & $3,3 \cdot 10^{-2}$ \\
\hline & & $1 \times 10^{-2}$ & $2,0.10^{-6}$ & $2,1.10^{-3}$ & $2,3 \cdot 10^{-2}$ \\
\hline \multirow{3}{*}{$12 \mathrm{~h}$} & \multicolumn{2}{|c|}{ Sem Inibidor } & $5,0.10^{-6}$ & $5,2 \cdot 10^{-3}$ & $5,8 \cdot 10^{-2}$ \\
\hline & \multirow{2}{*}{ 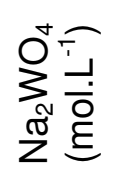 } & $5 \times 10^{-3}$ & $4,3.10^{-6}$ & $4,4 \cdot 10^{-3}$ & $5,0.10^{-2}$ \\
\hline & & $1 \times 10^{-2}$ & $2,3 \cdot 10^{-6}$ & $2,4.10^{-3}$ & $2,7.10^{-2}$ \\
\hline
\end{tabular}

Observando os resultados da Tabela 4.10 verifica-se que a presença do molibdato de sódio em meio de $\mathrm{NaCl}$ 3,5\% reduz a densidade de corrente de corrosão do aço para concentrações crescentes de molibdato de sódio. A perda de espessura foi reduzida em $50 \%$. Este resultado deve estar associado à formação de um filme de $\mathrm{FeMoO}_{4}$ sobre a superfície do metal, diminuindo as reações de dissolução do ferro. Para baixas concentrações de molibdato de sódio o filme formado de $\mathrm{FeMoO}_{4}$ é provavelmente menos espesso ou não é uniforme. No entanto, o aumento da concentração provavelmente aumenta a área de cobertura ou a espessura do filme de $\mathrm{FeMoO}_{4}$ (GUANNAN, 2006).

Os resultados obtidos com a presença do tungstato de sódio mostram que o íon $\mathrm{WO}_{4}{ }^{2-}$ também é capaz de reduzir a densidade de corrente de corrosão do açocarbono ABNT 1005 em meio de $\mathrm{NaCl} 3,5 \%$ e por conseguinte a perda de espessura. Observa-se também que a perda de espessura é menor para a maior 
concentração de tungstato de sódio, isto é, para uma concentração de $1 \times 10^{-2} \mathrm{~mol} . \mathrm{L}^{-1}$ de tungstato de sódio a perda de espessura é reduzida em $50 \%$ em relação ao meio sem a presença do íon $\mathrm{WO}_{4}{ }^{2-}$. Este comportamento provavelmente ocorre devido à reação do íon tungstato com o ferro formando um composto ferro tungstato (GANNAN, 2006). Portanto, a maior concentração do íon $\mathrm{WO}_{4}{ }^{2-}$ provavelmente intensifica as reações com a superfície metálica. As ligações do íon tungstato com o ferro devem favorecer na melhoria do filme formado tornando-o mais espesso.

Com o intuito de comparar os resultados obtidos com as substâncias estudadas como inibidores de corrosão, a seguir são apresentadas as curvas de polarização potenciodinâmicas anódicas e catódicas do aço-carbono ABNT 1005 em meio de $\mathrm{NaCl} 3,5 \%$ na ausência e na presença de diferentes concentrações de molibdato de sódio e tungstato de sódio, medidos com 24 horas de imersão. Os resultados estão apresentados nas Figuras 4.11 e 4.12.

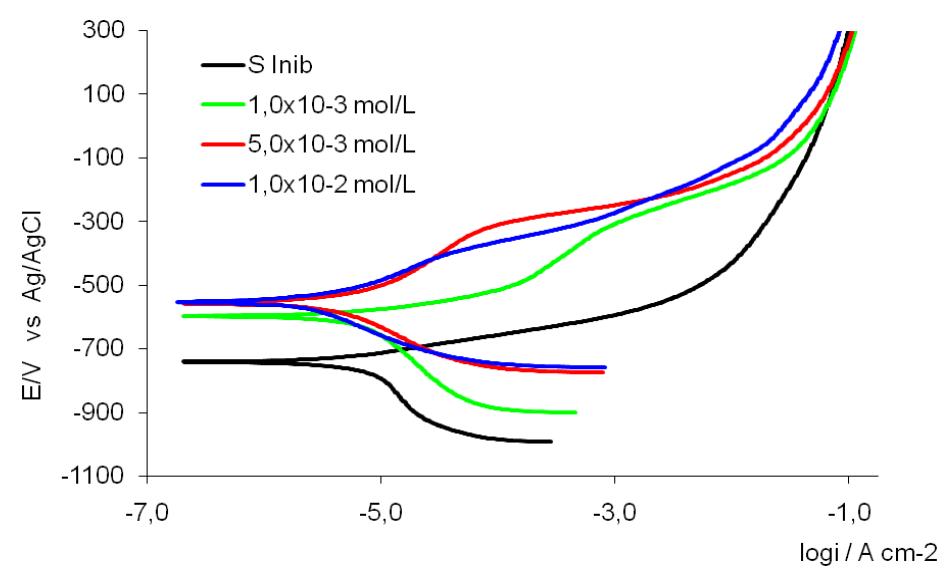

Figura 4.11 - Curvas de polarização potenciodinâmicas anódicas e catódicas para o aço-carbono ABNT 1005 em meio de $\mathrm{NaCl}$ 3,5\% na ausência e presença do $\mathrm{Na}_{2} \mathrm{MoO}_{4}$, com 24 horas de imersão. 


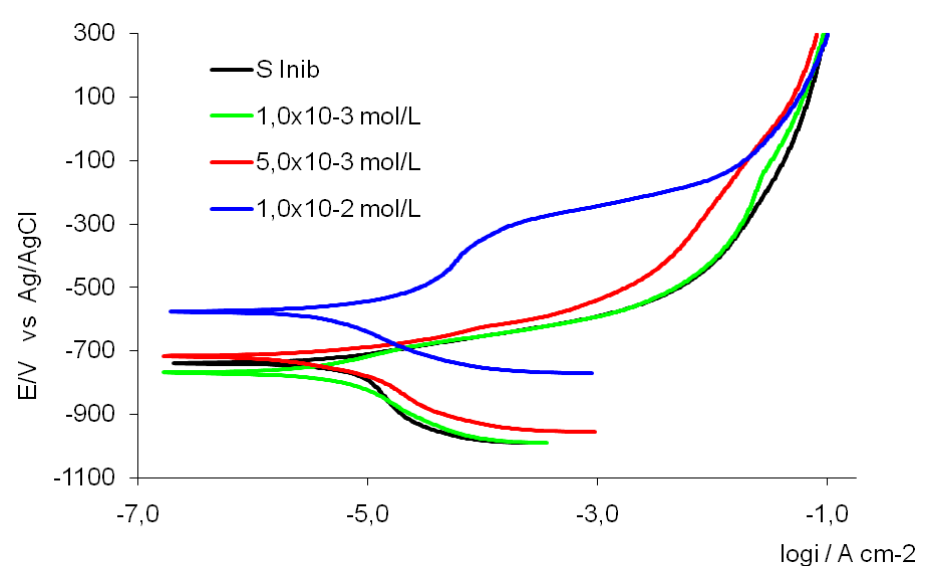

Figura 4.12 - Curvas de polarização potenciodinâmicas anódicas e catódicas para o aço-carbono ABNT 1005 em meio de $\mathrm{NaCl}$ 3,5\%, na ausência e presença do $\mathrm{Na}_{2} \mathrm{WO}_{4}$, com 24 horas de imersão.

As curvas de polarização apresentadas na Figura 4.11 (com e sem 0 molibdato de sódio) e na Figura 4.12 (com e sem o tungstato de sódio) são semelhantes. Observa-se claramente que todas as curvas de polarização anódicas foram polarizadas em relação à curva obtida na ausência das substâncias estudadas. Isto é, tanto na presença de molibdato de sódio quanto na de tungstato de sódio, apresentam-se polarizadas. Portanto, estes resultados revelam que os íons de molibdato de sódio e tungstato de sódio devam reagir com o óxido de ferro presente nos sítios anódicos do aço-carbono ABNT 1005 formando um filme que impede o contato do metal com o meio eletrolítico. Observa-se também que todas as curvas de polarização catódica encontram-se despolarizadas em relação à curva sem as substâncias.

Os resultados obtidos das curvas de polarização confirmam a tendência apresentada com os valores de potenciais de corrosão (Tab. 4.2), onde a presença do molibdato de sódio e do tungstato de sódio deslocou os potencias de corrosão para valores mais positivos. Finalmente, as curvas de polarização confirmam que tanto o molibdato de sódio quanto o tungstato de sódio agem como inibidores anódicos para o aço-carbono ABNT 1005 em meio de $\mathrm{NaCl}$ 3,5\%.

Para quantificar e melhor visualizar os resultados obtidos a Tabela 4.11 apresenta os valores de densidade da corrente de corrosão, $i_{c o r r}$, velocidade de

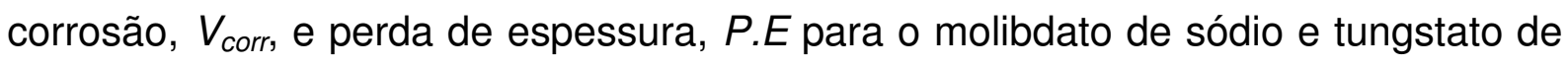
sódio, substâncias estudadas que apresentaram comportamento de inibidores de corrosão para o aço-carbono ABNT 1005 em meio de $\mathrm{NaCl}$ 3,5\%. 
Tabela 4.11 - Valores de densidade de corrente de corrosão $i_{\text {corr }}$, velocidades de corrosão, $V_{\text {corr }}$ e perda de espessura, P.E., do aço-carbono ABNT 1005 em meio de $\mathrm{NaCl} 3,5 \%$, na ausência e presença das substâncias estudadas, com 24 horas de imersão.

\begin{tabular}{|c|c|c|c|c|}
\hline \multicolumn{2}{|c|}{ Meio } & $i_{\text {corr }}\left(\mathrm{A} . \mathrm{cm}^{-2}\right)$ & $V_{\text {Corr }}\left(\mathrm{mg} \cdot \mathrm{cm}^{-2} \cdot \mathrm{h}^{-1}\right)$ & P.E. $\left(\mathrm{mm} . \mathrm{ano}^{-1}\right)$ \\
\hline \multicolumn{2}{|c|}{ Sem Inib } & $7,1 \cdot 10^{-6}$ & $7,4 \cdot 10^{-3}$ & $8,2.10^{-2}$ \\
\hline \multirow{3}{*}{ 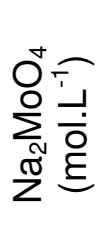 } & $1 \times 10^{-3}$ & $7,1.10^{-6}$ & $7,4 \cdot 10^{-3}$ & $8,2.10^{-2}$ \\
\hline & $5 \times 10^{-3}$ & $2,7.10^{-6}$ & $2,8.10^{-3}$ & $3,1.10^{-2}$ \\
\hline & $1 \times 10^{-2}$ & $1,3 \cdot 10^{-6}$ & $1,4 \cdot 10^{-3}$ & $1,5 \cdot 10^{-2}$ \\
\hline \multirow{3}{*}{ 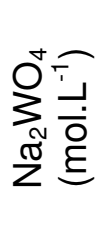 } & $1 \times 10^{-3}$ & $5,0.10^{-6}$ & $5,2 \cdot 10^{-3}$ & $5,8.10^{-2}$ \\
\hline & $5 \times 10^{-3}$ & $3,5.10^{-6}$ & $3,7.10^{-3}$ & $4,1 \cdot 10^{-2}$ \\
\hline & $1 \times 10^{-2}$ & $2,5 \cdot 10^{-6}$ & $2,6 \cdot 10^{-3}$ & $2,9 \cdot 10^{-2}$ \\
\hline
\end{tabular}

Os valores apresentados na Tabela 4.12 mostram que as substâncias estudadas agem como inibidores de corrosão. Observa-se que os melhores resultados foram obtidos com a presença do molibdato de sódio, seguido dos resultados obtidos do tungstato de sódio.

Chama-se à atenção para os resultados obtidos com a presença de molibdato de sódio, cuja redução da perda de espessura foi de $82 \%$ para uma concentração de $1 \times 10^{-2} \mathrm{~mol} \cdot \mathrm{L}^{-1}$.

A presença do tungstato de sódio, mesmo na menor concentração estudada, $1 \times 10^{-3} \mathrm{~mol}^{-L^{-1}}$, inibi a corrosão do aço-carbono ABNT 1005 em meio de $\mathrm{NaCl} 3,5 \%$, porém com a maior concentração, $1 \times 10^{-2}$ mol. $\mathrm{L}^{-1}$, a redução da perda de espessura foi de $65 \%$.

A Figura 4.13 apresenta as curvas de polarização que foram obtidas para o aço-carbono ABNT 1005 em meio de $\mathrm{NaCl} 3,5 \%$ na presença do copolímero a base de silano (CPPM). 


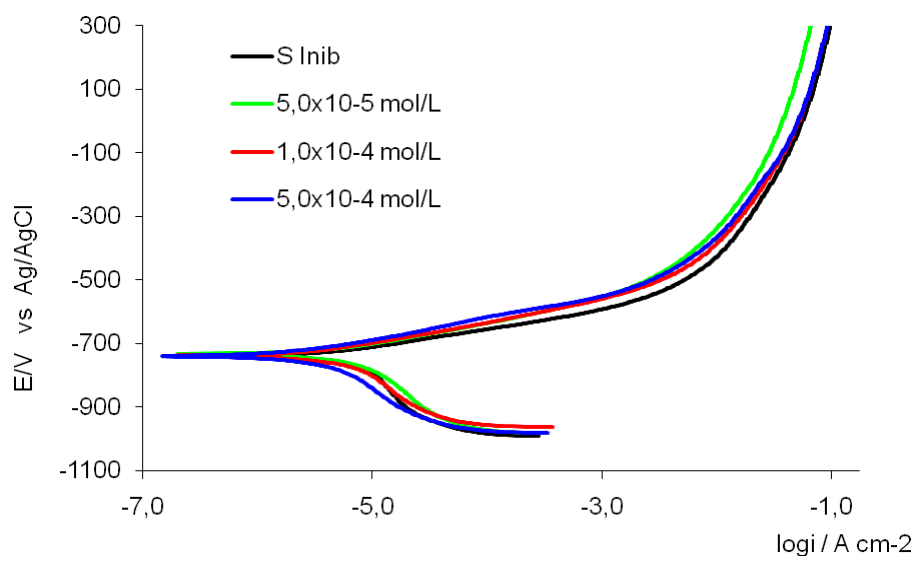

Figura 4.13 - Curvas de polarização potenciodinâmicas anódicas e catódicas para o aço-carbono ABNT 1005 em meio de $\mathrm{NaCl}$ 3,5\%, na ausência e presença do CPPM, com 24 horas de imersão.

A Figura 4.13 mostra que para todas as concentrações de CPPM e para toda faixa de potencial estudada, as curvas de polarização tanto anódicas quanto as catódicas não foram alteradas em relação aquelas obtidas na ausência do CPPM. Portanto, estes resultados são visivelmente concordantes com os demais resultados obtidos das diferentes técnicas estudadas. 


\section{CONCLUSÕES}

Através dos resultados obtidos neste trabalho pode-se conclui que:

\section{Ensaios de imersão com medida de perda de massa:}

- a velocidade de corrosão do aço-carbono ABNT 1005 exposto no meio de água do mar natural é menor que a velocidade de corrosão do metal exposto ao meio de $\mathrm{NaCl} 3,5 \%$.

\section{Medidas de potencial de corrosão:}

o molibdato de sódio e o tungstato de sódio deslocam os potenciais de corrosão para valores mais positivos, e crescentes com o aumento da concentração, em relação ao meio na ausência destas substâncias, indicando serem inibidores do tipo anódico para o aço-carbono ABNT 1005 em meio de $\mathrm{NaCl}$ 3,5\%;

- o copolímero a base de silano (CPPM) não altera o valor do potencial de corrosão do aço-carbono ABNT 1005 em meio de $\mathrm{NaCl} 3,5 \%$.

\section{Ensaios de espectroscopia de impedância eletroquímica:}

- o molibdato de sódio e o tungstato de sódio agem como inibidores da corrosão do aço-carbono ABNT 1005 em meio de $\mathrm{NaCl}$ 3,5\%, e a eficiência de inibição é crescente com o aumento da concentração das substâncias estudadas, presentes no meio;

- as substâncias estudadas como inibidores de corrosão formam filmes mais protetores para diferentes tempos de imersão, isto é, o filme formado em 6 horas de imersão na presença do molibdato de sódio é mais protetor, enquanto que o filme formado em 12 horas de imersão na presença do tungstato de sódio é mais protetor;

- o ín molibdato provavelmente interaje com o óxido de ferro formado sob a superfície do aço, formando um filme protetor de ferro molibdato, porém este filme torna-se menos protetor com o aumento do tempo de imersão; 
- o aumento da capacitância da dupla camada elétrica, $C P E_{d l}$, para concentrações crescentes de molibdato de sódio e tungstato de sódio indica que provavelmente deve haver uma forte interação entre 0 íon $\mathrm{MoO}_{4}{ }^{2-}$ e o íon $\mathrm{WO}_{4}{ }^{2-}$ com o óxido formado na superfície do aço;

- os resultados obtidos com o copolímero a base de silano (CPPM) não foram significativos.

\section{Curvas de polarização potenciodinâmicas anôdicas e catódicas:}

- o molibdato de sódio e o tungstato de sódio são inibidores do tipo anódico para o aço-carbono ABNT 1005 em meio de $\mathrm{NaCl} 3,5 \%$;

- o molibdato de sódio, tungstato de sódio reduzem a densidade de corrente de corrosão do aço-carbono no meio estudado;

- a perda de espessura foi reduzida em 50\% com a presença de $1 \times 10^{-2} \mathrm{~mol}^{-1} \mathrm{~L}^{-1}$ de molibdato de sódio com 6 horas de imersão e de 82\% com 24 horas de imersão, comparado com o valor obtido em $\mathrm{NaCl} 3,5 \%$ sem inibidor;

- a presença de $1 \times 10^{-2}$ mol. $L^{-1}$ de tungstato de sódio com 12 horas de imersão reduziu a perda de espessura em 50\% e de 65\% com 24 horas de imersão, comparado com o valor obtido em $\mathrm{NaCl} 3,5 \%$ sem inibidor;

- o copolímero a base de silano não age como inibidor de corrosão para o açocarbono ABNT 1005 em meio de $\mathrm{NaCl} 3,5 \%$. 


\section{REFERÊNCIAS}

ABDALLAH, M.; EL-ETRE, A. Y.; SOLIMAN, M. G.; MOBROUK, E. M. Some organic and inorganic compounds as inhibitors for carbon steel corrosion in 3.5 percent $\mathrm{NaCl}$ solution. Anti-corrosion methods and materiais, vol 53, № 2, p. 118-123, 2006

ASSOCIAÇÃO BRASILEIRA DE NORAMAS TÉCNICAS. ABNT/CB-CB 28: Projeto de estruturas de aço e de estruturas mistas de aço e concreto de edifícios projeto de revisão 8800. Rio de Janeiro, abr. 2007.

ALENTEJANO, C. R; Aoki, I. V. Localized corrosion inhibition of 304 stainless in pure water by oxyanions tungstato and molybdate. Electrochimica Acta, vol. 49, p. 27792785, 2004.

ANTUNES, R. A.; COSTA, I. Caracterização de produtos de corrosão de aço carbono e aço patinável submetidos a ensaio acelerado de corrosão e ensaio de intemperismo. In: 22ํONBRASCORR (Congresso Brasileiro de Corrosão), 2002, Salvador-BA. Anais. 6 COTEQ: Salvador-BA, 2002.

AIROLDI, C.; FARIAS, R. F. O uso de sílica gel organofuncionalizada como agente sequestrante para metais. Quím. Nova, São Paulo, v. 23, n. 4, 2000 . Disponível em:<http://www.scielo.br/scielo.php?script=sci_arttext\&pid=S0100$40422000000400012 \&$ Ing=en\&nrm=iso>. Acesso em: 10 Jul 2008.

ATKINS, P.; JONES, L. Princípios de Química. Tradução de Ignez Caracelli e Julio Zukerman-Schpector. Porto Alegre: Bookman, 1999, 914 p., p. 603.

AZAMBUJA, D. S.; MARTINI, E.A.; MÜLLER, L. Corrosion behaviour of iron and AISI 304 Stainless Steel in tungstate aqueous solutions containing choloride. J. Braz. Chem., vol 14, № 4, 570-576, 2003.

BATISTA, E. M; GHAVAMI, K. Development of brazilian steel construction. Journal of Constructional Steel Research, № 61, p. 1009-1024, 2005.

BENTLEY, A. J.; EARWAKER, L. G.; SAREMI, M.; SEENEY, A. M. Molibdates in aqueous corrosion inhibition - III. Effects of molybdate in the anodic filming of steel. Polyhedron, 15, n. 1-2, p. 547-550, 1986. 
BONORA, P. L.; DEFLORIAN, F.; FREDRIZZI, L. Eletrochemical impedance spectroscopy as a tool for investigating underpaint corrosion. Eletrochimica Acta, 41, n. $7 / 8$, p. 1073-1082, 1996.

BRETT, A. M., BRETT, C. M. Eletroquímica, princípios, métodos e aplicações. Oxford University Press, 1993, $471 \mathrm{p}$.

Chiaverini, V. Aços e ferros fundidos: características gerais, tratamentos térmicos, principais tipos. São Paulo: Associação Brasileira de Metalurgia e Materiais, 7. ed., 2002, 599 p., p. $19 / 22$

Corrosão em água salgada. Disponível em: < http://www.cimm.com.br/portal/cimm/ iframe/?pagina=/cimm/construtordepaginas/htm/3_24_10286.htm>. Acesso em: Ago. 2008.

DEMARQUE, R. M.; MATAI, P. H. L. S.; AOKI, I. V.; GUEDES, I. C. Estudo de um tensoativo a base de organo-silano como inibidor de corrosão para o aço ABNT 1005 em meio de $\mathrm{HCl}$ 5\%, In: SIMPÓSIO BRASILEIRO DE ELETROQUÍMICA E ELETROANALÍTICA, Londrina, 2005. XV SIBEE: Anais. Londrina: Universidade Estadual de Londrina. Em CD-ROM.

DILLON, C. P. Corrosion control in the chemical process industries. Materials Technology Institute of the Chemical Process Industries, Inc. Published for MTI by NACE International, 1997, 424 p.

DURING, E. D. D. Corrosion atlas: a collection of illustrated case histories. $2^{\text {nd }}$ ed. rev. Amsterdan: Elsevier, 1991. 2 v.

DUTRA, A. C. Proteção catódica: técnica de combate à corrosão. $4^{a}$ ed. Rio de Janeiro: Interciência, 2006, 236 p.

FARR, J.; SAREMI, M. Molibdate in aqueous corrosion inhibition, part II: effects of molybdate, citrate and phosphate on the anodic behaviour of steel. Surface Technology, vol. 17, p. 19-27, 1982.

Molibdate in aqueous corrosion inhibition, part I: effects of molybdate on the potentiodynamic behaviour of steel and some other metals. Surface Technology, vol. 19, p. 137-144, 1983. 
FAVAHERDASHTI, R. How corrosion effects industry and life. Anti-corrosion Methods and Materials, vol 47, n. 1, p. 30-34, 2000.

FONTANA, M. G. Corrosion engineering, 3. ed., New York: McGraw Hill, 1987, $556 \mathrm{p}$.

FREE, M. L. Understanding the effect of surfactant aggregation on corrosion inhibition of mild steel in acidic medium. Corrosion Science, v. 44, n. 12, p. 28652870, 2002.

FREEDMAN, A.J. Cooling water treatment: process industries corrosion. National Association of Corrosion Engineers, Pollock-Editors, 1986.

GENTIL, V. Corrosão. $2^{\underline{a}}$ ed.. Rio de Janeiro: Editora Guanabara Dois S.A - RJ, 1983, $453 \mathrm{p}$.

GOMIDE, R. Operações unitárias: operações com transporte de massa, $4^{\circ}$ vol. São Paulo: Edição do autor, 1988, p. 314-315.

GRUNDIG, W. Corrosão Metálica. In: BRADASCHIA, Corrosão e tatamentos superficiais dos metais. São Paulo: Associação Brasileira de Metais, 1971, p. 1318.

GUANNAN, M.; XIANGHONG, L.; QING, Q.; JUN, Z. Molybdate and tungstate as corrosion inhibitors for cold rolling steel in hydrochloric acid solution. Corrosion Science, vol. 48, p. 445-459, 2006.

GUEDES, I. C. Eficiência dos inibidores de corrosão benzotriazol, nfeniltiouréia e cloreto de hexadeciltrimetil amônio quaternário para ferro puro, aço carbono e aço ARBL em meio de ácido sulfúrico. Tese (Doutorado), Escola Politécnica, Universidade de São Paulo, São Paulo, 1996.

Hsu,C. H.; Mansfeld, F. Concerning the conversion of the constant phase element parameter $y_{0}$ into capacitance. Corrosion Science, vol. 57, n. 9, 2001.

JEYAPRABHA, C.; MURALIDHARAN, S.; JAYAHPERUMAL, D.; VENKATACHARI, G.; RENGASWAMY, N. S. Studies on corrosion inhibitors for oil-well tubular material in acid environments. Anti-corrosion Methods and Materials, vol. 45, n. 3, p. 148152, 1998. 
JORCIN, J. J.; ORAZEM, M. E.; PÉBÈRE, N. CPE analysis by local electrochemical impedance spectroscopy. Electrochimica Acta, no 51, 2006, 1473-1479.

KHODAKOV, I. V.; EPSTEIN, D. A.; GLORIÓZOV, P. A. Química inorgânica, vol. 2. Tradução de Maria Helena Fortunado. Rússia: Editora Mir Moscou, 207 p., p. 135, 1984.

LEE, J. D. Quimica inorgânica: um novo texto conciso, 3ª ed. Tradução de Juergen Heinrich Maar. São Paulo : Edgard Blucher, 1980. 507 p.

LI, Q. X., WANG, Z. Y., HAN, W., HAN, W. H. Characterization of the corrosion products formed on carbon steel in Qinghai salt lake atmosphere. Corrosion Science section, vol. 63, n. 7, July 2007.

MAIA, J. L. C.; BARROS, M. T. L. Auditorias de processo em instalações marítimas de produção de petróleo. Boletim Técnico Petrobras, Rio de Janeiro, vol. 46, n. 34, p. 196-207, jul. a dez. 2003.

MAINIER, F.B.; SILVA, R.R. As Formulações Inibidoras de Corrosão e o Meio Ambiente. Engevista, v. 6, n. 3, p. 106-112, 2004.

MALIK, H. Charge and $\mathrm{pH}$ effects on inhibitor performance. Anti-Corrosion Methods and Materials, vol. 48, n. 6, p. 364-70, 2001.

MELO, H. G. Impedância eletroquímica aplicada ao estudo da corrosão e de processos de proteção. São Paulo: PQI/EPUSP, 2003. Notas de aula da disciplina PQI 5847.

MIKSIC, B., BOYLE, R., WUERTZ, B. 2004 F.N. speller award lecture: efficacy of vapor phase corrosion inhibitor technology in manufacturing. Corrosion Science, vol. 60, n. 6, p. 515-522, 2004.

MISAWA, T.; HASHIMOTO, K.; SHIMODAIRA, S. The mechanism of formation of iron oxide and oxyhydroxides in aqueous solutions at room temperature. Corrosion Science, vol. 14, p 131-149, 1974. 
NOGUEIRA, P.M. Estudo da viabilidade da utilização de filmes de carbono tipo diamante como camada de revestimento interno em dutos de transporte de petróleo. Boletim Técnico Petrobras, Rio de Janeiro, vol. 45, n. 2, p. 66-113, abr./jun., 2002,

NUNES, L. P. Fundamentos de resistência à corrosão. Rio de Janeiro: Interciência, IBP: ABRACO, 2007 , 330 p.

OCHOA, N.; BARIL, G.; MORAN, F.; PÉBÉRE, N. Study of the properties of a multicomponent inhibitor used for water treatment in cooling circuits. Journal of Applied Electrochemistry, vol. 32, p. 497-504, 2002.

PALANIVEL, V.; HUANG, Y.; OOIJ, W. J. Effects of addition of corrosion inhibitors to silane films on the performance of AA2024-T3 in a $0,5 \mathrm{M} \mathrm{NaCl}$ solution. Progress in Organic Coating, vol. 53, p. 153-168, 2003.

PANOSSIAN, Z. Corrosão e proteção contra corrosão em equipamentos e estruturas metálicas: vol.1, 1aㅡ ed. São Paulo: Instituto de Pesquisas Tecnológica, 1993, p. 281.

. Corrosão e proteção contra corrosão em equipamentos e estruturas metálicas: vol. 2, $1^{\text {a }}$ ed. São Paulo: Instituto de Pesquisas Tecnológica, 1993, p. 636.

PATTON, C. C. Corrosion Control in Water Injection Systems. Dallas: Environmental Effects. Material Performance, vol. 32, n. 8, ago. 1993.

Perry, R. H; Green, D. W.; Maloney, J. O. Perry's chemical engineers' handbook. $7^{\mathrm{TH}}$ ed, New York: McGraw-Hill, c1997, 1 v.

REIS, F. M. Novo tratamento de superfície isento de metais pesados. Tratamento de superfície, n. 131, p. 26-30, 2005.

Robertson, W. D. Molybdate and tungstate as corrosion inhibitors and the mechanism of inhibition. Jornal of the Electrochemical Society, p. 94-100, march 1951.

SAKASHITA, M.; SATO, N. The effect of molybdate anion on the ion-selectivity of hydrous ferric oxide films in chloride solutions. Corrosion Science, vol. 17, p. 473486, 1977. 
SAREMI, M.; DEHGHANIAN, C.; SABET, M. M. The effect of molybdate concentration and hydrodynamic effect on mild steel corrosion inhibition in simulated cooling water. Corrosion Science, vol. 48, p. 1404-1412, 2006.

SASTRI, V. S. Corrosion inhibitors: principles and applications. Chichester. New York: Wiley, c1998, $903 \mathrm{p}$.

SCHAFTINGHEN, V. T.; PEN, L. C; TERRYN, H.; HÖRZENBERGER, F. Investigation of the barrier properties of silanes on cold rolled steel. Eletrochimica Acta, 49, p. 2997-3004, 2004.

SHALABY, M. N.; OSMAN, M. M.; El FEKY, A. A. Effect of some organix surfactantes on corrosion inhibition of steel in sea water. Anti-corrosion methods and materials, v. 46, n. 4, p. 254-260, 1999.

SHAMS, A.M.; WANG, L. Mechanism of corrosion inhibition by sodium molybdate. Desalination, 107, p. 29-43, 1996.

SHARP, D. W. The Peguin dictionary of chemistry. $3^{\text {rd }}$ ed. London: Published by the Peguin group, 2003.

SHREIR, L. L.; Jarman, R. A.; Burstein, G. T. Corrosion: v.1 - metal e environment reaction. $3^{\text {rd }}$ ed., Oxford. Boston: Butterworth-Heinemann, 1994, $21: 95$ p.

$3^{\text {rd }}$, Oxford; Boston: Butterworth-Heinemann, $1994,21: 95$ p.

Corrosion: v. 2 - corrosion control.

SOUZA, P. R. Comportamento de três moléculas do tipo organo-silano como inibidores de corrosão para o aço ABNT 1005 em meio de HCl 2 M. 2005. Dissertação (Mestrado), Escola Politécnica da Universidade de São Paulo, São Paulo, 2005.

SPELLER, F.N. Corrosion in refrigeration plant. American Society of Refrigeration of Engineers, circ. 10, 1930.

SUBRAMANIAN, V.; OOIJ, W. J. Effect of the amine function group on corrosion rate of iron coated with films of organofunctional silanes. Corrosion Science Section, vol. 54, n. 3, p. 204-215, march 1998. 
Silane based metal pretreatments as alternatives to chromating. Surface Engineering, vol. 15, n. 2, p. 168-172, 1999.

TRABANELLI, G. Corrosion inhibition. In: MANSFELD, F. Corrosion mechanism. New York: Marcel Dekker, p. 119-142, 1987,.

TRABANELLI, G. Fundamental and general aspects fo inhibition science. In: Raman, A.; Labine, P. Reviews on corrosion inhibitor science and technology. Houston: Nace, 1993, p. I-2-1 a I-2-5 e I-2-8 a I-2-9.

UHLIG, H. H. Corrosion handbook. New York: J. Wiley, 1948, 1188 p.

VIRTANEN, S.; SURBER, P.; NYLUND P. Influence of $\mathrm{MoO}_{4}{ }^{2-}$ anion in the electrolyte on passivity breakdown of iron. Corrosion Science, vol. 43, p. 11651177, 2001.

VILLARROEL, V.; AOKI, I. V; GUEDES, I. C. Avaliação do filme formado por molibdato de sódio sob o aço carbono ABTN 1005 em meio de água do sistema de resfriamento industrial quanto às características de inibição da corrosão, COTEQ050. In: 25CONBRASCORR (Congresso Brasileiro de Corrosão), 2007, SalvadorBA. Anais. 9 COTEQ: Salvador-BA, 2007. CD-ROOM.

VUKASOVICH, M. S.; FARR, J. P. G. Molybdate in corrosion inhibition - a review. Poyhedron, vol 5, n. 1-2, p. 551-559, 1986.

VUKASOVICH, M. S.; ROBITAILLE, D. R. Corrosion inhibition by sodium molybdate. Jornal of the Less-Common metals, 54, p. 437-448, 1977.

WANG, W.; FREE, M. L. Prediction and measurement of corrosion inhibition of mild steel using nonionic surfactants in chloride media. Corrosion Science, vol. 46, p. 2601-2611, 2004.

WOLYNEC, S. Técnicas eletroquímicas em corrosão. São Paulo: Editora da Universidade de São Paulo, 2003. 166 p.

YUCHUN, L.; XUNJIE, G.; KERU, P.; YUMBO, L. Study on inhibitive mechanisms of molybdate used in combination with phosphate in neutral environments. AntiCorrosion Methods and Materials, vol. 49, n. 1, p. 38-41, 2002. 